\title{
The dynamics of informal care provision in an Australian household panel survey: Previous work characteristics and future care provision
}

\author{
Ha Trong Nguyen* \\ Curtin University
}

\section{Luke B. Connelly}

The University of Queensland

\begin{abstract}
This study contributes to a small literature on the dynamics of informal care by examining the informal care provision choices of working age Australians. We focus on the impact of previous work characteristics (including work security and flexibility) on subsequent care provision decisions and distinguish between care that is provided to people who cohabit and people who reside elsewhere, as well as between the provision of care as the primary caregiver, or in a secondary caring role. Our dynamic framework of informal care provision accounts for state-dependence, unobserved heterogeneity and initial conditions. For both males and females, we find the existence of positive state-dependence in all care states in both the short- and medium-term. Furthermore, the inertia in care provision appears to be stronger for more intensive care. We also find previous employment status has a significant deterrent effect on current care provision decisions. The effects on employment, however, differ according to the type of previous work, the type of care currently provided, and the gender of the caregiver. We also find that workers with perceptions of greater job security are nevertheless less likely to provide subsequent care. Our results also suggest that workers' perceptions about work flexibility and their stated overall satisfaction with work actually have no impact on their subsequent decisions to provide care in any capacity.
\end{abstract}

Keywords: informal care, labour supply, dynamic multinomial choice models, panel data.

JEL classification: C23, J14.

\footnotetext{
* Corresponding author: Bankwest Curtin Economics Centre | Curtin Business School | Curtin University | Tel:+61 892665711 |Fax:+61 892662373 | Postal: GPO Box U1987, Perth WA 6845, Australia | Email: ha.nguyen@curtin.edu.au.

Acknowledgements: We thank the editor, Garry Barrett, and two anonymous referees for their suggestions. We also thank Peter Haan, the author of the mixlogit command, for corresponding with us regarding its implementation. We also thank participants at the 25th Australian Labour Market Workshop, the Asian-Pacific Conference on Economic Dynamics (APCED) 2013 and the Netspar International workshop for their comments and suggestions. This paper uses unit record data from the Household, Income and Labour Dynamics in Australia (HILDA) Survey. The HILDA Project was initiated and is funded by the Australian Government Department of Social Services (DSS) and is managed by the Melbourne Institute of Applied Economic and Social Research (Melbourne Institute). The findings and views reported in this paper, however, are those of the authors and should not be attributed to either DSS or the Melbourne Institute.
} 


\section{Introduction}

There is a large extant multidisciplinary literature on caregiving and the relationship between the provision of informal care-especially eldercare-on labour force participation (LFP), productivity and earnings. ${ }^{1}$ Most of that literature does not, however, consider the dynamics that are associated with caregiving and labour market decision-making processes. Indeed, the literature on dynamics and caregiving is extremely small, as is documented by Sovinsky and Stern's (2016) recent, thoroughgoing review.

As Sovinsky and Stern (2016) argue, there are numerous reasons this evidence gap should be addressed. First, the decision-making processes themselves are likely inherently dynamic: human capital accumulation in respect of care provision; work-related human capital depreciation due to extended periods out of the labour force; carer burnout; the declining health status of those for whom care is provided, as well as (potentially) for carers; spending down of wealth (e.g., to qualify for state subsidies for long-term care) and so on, are processes with dynamic effects that may affect decision-making. For instance, the difficulty of returning to the labour force is likely to be an increasing function of time away from it, and caring may become easier or harder with time depending upon whether learning is involved or the health of the care recipient declines with time (Michaud et al., 2010). Second, one should beware that ignoring dynamics could also cause one to estimate other parameters with bias, rendering policy analyses based on them flawed (Berkovec and Stern, 1991; Sovinsky and Stern, 2016).

As the population ages and policy-makers consider ways to improve the workforce participation of specific groups (e.g., older women), understanding the dynamics of informal care and labour force participation is of increasing importance. Distinguishing true dynamic effects from unobserved heterogeneity, in particular, and determining the precise nature of dynamic effects, will provide relevant empirical insights in this regard. For instance, how much of the persistence that may be observed in caregiving is due to pure state dependence (i.e., the effect of the present state on the future "environment, preferences or technology" (Sovinsky and Stern, 2016, p 464), how much of it is due to true duration dependence (e.g., due to human capital accumulation or depreciation), and how much is attributable simply to unobserved heterogeneity? By controlling appropriately for initial conditions and unobserved

\footnotetext{
${ }^{1}$ For recent discussions of that literature see, e.g. the reviews contained in Sovinsky and Stern (2016) and Nguyen and Connelly (2014).
} 
heterogeneity, measures of true state dependence may be retrieved from work of the kind presented here.

In this paper, we present estimates of the first dynamic models of informal care provision for working age Australians. In our empirical work, we also recognize the possible differences in caregiving patterns between males and females by analysing males and females separately. In addition, we employ more detailed classifications of informal care provision and labour market outcomes than have generally been used in the international literature to date. Another novel aspect of the work is our use of indicators that represent perceived job security and flexibility in order to assess the impact of previous work characteristics on future decisions to provide care. To the best of our knowledge, this is the first such contribution to the literature.

The work reported in this paper uses panel data drawn from seven waves of the Household, Income and Labour Dynamics in Australia (HILDA) survey and employs a dynamic multinomial framework that accounts for state-dependence, unobserved heterogeneity and initial conditions. We find strong evidence of positive state-dependence in all care provision states. We find that care provision is persistent for both males and females in the short- and the medium-term and that this persistence appears to be stronger for more intensive types of care. In addition, we find that caregiving is employment state-dependent: previous employment status does affect caregiving choices in subsequent periods. The impact varies, though, according to the type of previous work, type of subsequent care, and the carer's gender. We find that workers with perceptions of better job security are actually less likely to be care providers in subsequent years. Workers' perceptions about the flexibility of work and their overall work satisfaction have no apparent influence on their subsequent decisions to provide care in this dataset.

The remainder of this paper is structured as follows. Section 2 provides an overview of the relevant literature. Section 3 introduces the data and presents some descriptive statistics. The empirical models are then introduced in Section 4, and in Section 5 we present the results. Section 6 concludes the paper.

\section{Literature review}

Three different strands of the literature are particularly relevant to this study. The first deals with the decision to provide care for others. Theoretically, the motivations for informal caregiving can be classified into a taxonomy of altruism (Becker, 1974), exchange (Bernheim et al., 1985; Cox, 1987; Cox and Rank, 1992) and demonstration (Cox and Stark, 1996) 
motives, or some mixture of these three. Although most empirical studies do not seek to test hypotheses that pertain to these supposed motivations ${ }^{2}$ they do shed some light on the factors that drive informal caregiving decisions. For example, individuals with higher incomes are less likely to become caregivers (Couch et al., 1999; Mentzakis et al., 2009; Carmichael et al., 2010) due to the higher opportunity cost of time. The question of whether or not previous work experience per se affects the probability of providing care is equivocal: some empirical studies suggest that previous work experience lowers the probability of care provision (Mentzakis et al., 2009; Carmichael et al., 2010; Michaud et al., 2010) while others (Stern, 1995; Berecki-Gisolf et al., 2008) do not.

A number of studies in the long-term care literature have focused on the dynamics of longterm care arrangements. For instance, Borsch-Supan et al. (1992) study the dynamics of living arrangements of the U.S. elderly. Similarly, Dostie and Léger (2005) examine the transitions of living arrangements of sick, elderly individuals in the U.S.; while Gardner and Gilleskie (Gardner and Gilleskie, 2012) estimate a dynamic model of long-term care arrangements, assets/gift behaviour, health insurance benefits, and health transitions for a sample of the U.S. elderly. Goeree et al. (2012) estimate dynamic models of elder-care arrangements using U.S. data. So far, all U.S. studies in this literature appear to focus on the long-term care arrangements of elderly which are arguably most closely related to the demand side of long-term care.

To the best of our knowledge, only two studies have focused on the supply side factors in unpaid care markets - which is the primary focus of the current paper. Both of those studies use data from the British Household Panel Survey (BHPS) (Mentzakis et al., 2009; Michaud et al., 2010). Mentzakis et al. (2009) employ a random-effects dynamic model to analyse the dynamics of care provision by males and females in the U.K. They focus on caring for residential spouses and children and use a two-part model to distinguish care participation and the levels of care provided. Similarly, using a framework that deals with unobserved heterogeneity and state-dependence, Michaud et al. (2010) examine the dynamics of informal care provision and employment outcomes for females in the U.K.

The second and rather rich literature deals with the impact of informal caregiving on caregivers' labour force participation (LFP). Most studies have found evidence of a negative

\footnotetext{
2 Two U.S. studies by Brown (2006) and Norton et al. (2013) are exceptions. They both document that children who provide care to their elderly parents are more likely to receive financial transfers from the parents than children who do not provide care.
} 
correlation between informal care and LFP. However, the magnitude of the negative correlation varies across studies, ranging from an almost negligible effect (Van Houtven et al., 2013) to a 42 percentage point reduction (Heitmueller, 2007) in the LFP rate. The existing literature has also uncovered significant heterogeneity of the effect of informal care on LFP: specifically, the impact appears to be stronger for intensive caregivers (Carmichael and Charles, 2003; Lilly et al., 2010; Casado-Marín et al., 2011; Nguyen and Connelly, 2013) or residential caregivers (Ettner, 1996; Carmichael and Charles, 2003; Heitmueller, 2007; Casado-Marín et al., 2011; Nguyen and Connelly, 2013).

The third line of literature examines the impact of workplace flexibility on care provision and work retention decisions. In spite of the policy interest in promoting flexible working, little is known about the extent to which workplace flexibility actually affects care provision decisions. Studies have so far focused on samples of employees and have produced quite mixed results. For example, Pavalko and Henderson (2006) document that, among employed U.S. females who started providing care, people in jobs which offer more flexible working hours or more generous job benefits (as measured by unpaid family leave or paid sick or vacation days) were more likely to remain employed and maintain their work hours over a two-year period. Similarly, Bryan (2012) uses cross-sectional British employee data and shows that workers in more flexible jobs are more likely to provide care. By contrast, using British cross-sectional data, which contain retrospective information about informal care and employment, Henz (2006) shows that starting caregiving is not affected by work flexibility. ${ }^{3}$

Some related studies have recently suggested that work flexibility may have some impact on employees' future work and care decisions. Zuba and Schneider (2012), for instance, use cross-sectional employee data from Europe to show that employees who provide informal care exhibit higher levels of perceived work-family conflict than workers who do not provide informal care. Similarly, using a cross-sectional sample of Austrian employees, Schneider et al. (2013) show that female employees with more flexible work arrangements are less likely to report that they intend to change jobs when facing a demand for informal care provision. If work and informal care are substitutable and job change intentions are good proxies for actual job changes, the finding by Schneider et al. (2013) may be interpreted as showing that job flexibility facilitates future care provision.

\footnotetext{
${ }^{3}$ Unfortunately, since there is no direct information about job flexibility in the data Henz (2006) has to use aggregate measures which were derived using socio-economic class. As Henz (2006) notes, these derived measures of work flexibility may make it more difficult to detect effects.
} 
In summary, there are several strands of literature that are germane to the work presented in this paper. The previous empirical work in this field does not provide conclusive evidence on the effect of, for instance, flexible work arrangements on employees' decisions to provide care. It is also difficult to draw a causal interpretation from the correlation between work characteristics and care provision decisions from some of these studies: many have had to use on cross-sectional data, and hence have been unable to control for unobserved heterogeneity or with the problems associated with the strong possibility of selection into work or care. Our panel data and ability to implement a dynamic framework enables us to account for statedependence, unobserved heterogeneity and initial conditions. These advantages of the data and empirical framework implemented in the current paper enable us to draw robust inferences regarding the causal impact of previous work characteristics (including job security and flexibility) on subsequent decisions to provide care.

\section{Data and descriptive analyses}

\subsection{Data}

This study utilises the Household Income and Labour Dynamics in Australia (HILDA) survey, a nationally representative household-based panel survey which began in 2001. There are approximately 7,000 households and 13,000 individuals who respond in each wave. HILDA contains rich information on household formation, income and work. We use Waves 5 to 11 since these seven waves contain the detailed information on informal care that is required for our work. ${ }^{4}$

\subsection{Sample}

For this study, we restrict the sample to individuals aged between 24 and 64, excluding individuals at school or undertaking other full-time study. We thus obtain a balanced sample which consists of 5,427 unique individuals. ${ }^{5}$ From these individuals, we exclude a further 1,581 individuals on the basis that they entail missing information on important variables. ${ }^{6}$

\footnotetext{
${ }^{4}$ We do not use Waves 1 to 4 since no direct information about informal care is available in these waves.

${ }^{5}$ A balanced sample is required as we use the Wooldridge (2005) approach to account for the initial conditions problem (Wooldridge, 2005, p 44). Using a balanced sample of individuals who are observed at every year over the seven year period also helps improve the performance of the Wooldridge (2005) approach as found in the literature (Arulampalam and Stewart, 2009; Akay, 2012).

6 Most of missing information is due to variables describing demand for care (See Section 4 for details). Information on these variables is derived from a mail-back self-completed questionnaire. About $90 \%$ of respondents returned this questionnaire. For these variables we lose 1,568 unique observations mostly because respondents did not return a self-completed questionnaire. See Appendix Table A1 for variable description.
} 
Thus, we have a balanced sample of 3,846 unique individuals, $54 \%(2,058)$ of whom are female.

There are several reasons that individuals may enter or exit the final sample, including original sample attrition, missing information on important variables, and the fact that we must observe an individual over the whole period to apply our empirical econometric models. While reasons for original sample attrition are discussed elsewhere (Watson, 2012), we investigated whether our sample selection criteria led to sample selection issues. One particular concern relating to our research design is that caregiving status may affect the probability that an individual is included in the final sample. Therefore, we ran a probit model where the dependent variable is equal to one if the individual is in our sample and zero otherwise. The explanatory variables are basic demographic characteristics, including caregiving variables. Regression results (reported in Appendix Table A5) suggest some evidence of statistically significant selection on some observables. For example, individuals in our sample tended to be older, native, better educated, married, healthier, wealthier, or to have healthier family members. However, the pseudo- $\mathrm{R}^{2}$ values are small, indicating that selection on observable characteristics is quantitatively weak. More importantly, $p$-values from a $t$ test for statistical significance of the caregiving variables included in the regression are greater than 0.60 , alleviating concern that our results may be driven by sample selection.

\subsection{Definition of unpaid caregiving intensity}

In our data, informal caregivers are individuals who provide unpaid assistance with activities of daily living to a person who requires care due to a long-term health condition, old age or disability. We first follow Michaud et al. (2010) to identify care provision by residency status between the caregiver and care recipient, classifying caregivers as either "resident" caregivers or "non-resident" caregivers. ${ }^{7}$ In addition, our dataset contains further information about caregivers: namely, whether or not the caregiver identifies as the primary caregiver. ${ }^{8} \mathrm{We}$ classify caregivers who answer "yes" to the question "Are you the main carer of [this

\footnotetext{
${ }^{7}$ A small number of individuals (comprising less than $0.5 \%$ of our sample) reports providing care for both residents and non-residents at the same time. Because resident care is more intensive than non-resident care (Nguyen and Connelly, 2014) we classify these individuals as resident caregivers. Similarly, when defining care provision by care intensity we assign them as main caregivers if they indicate that that provide care for either residents or non-residents as main carers. The results however are not sensitive to the exclusion of these individuals from our sample.

${ }^{8}$ Theoretically, care provision can be identified by both residency and intensity. However, in practice, transitions between some care groups (for example, among those identified as secondary resident caregivers in the previous year, none of them switched to provide care for non-residents (either as main or secondary caregivers) in the following year) are not large enough for us to estimate a dynamics model of care provision.
} 
person]?" as the "main caregiver" (or, the "main carer"), while those who answer "no" are classified "secondary caregivers". 9 Previous studies using data from the U.K. (Carmichael and Charles, 2003), Canada (Lilly et al., 2010) and Australia (Nguyen and Connelly, 2014) have found this measure of care intensity to be robust and reliable. Our data (see Appendix Table A2) also show that, on average, as compared to secondary caregivers, main caregivers appear to spend more weekly hours on care and are more likely to receive carer benefits (either in the form of a Carer Payment or Carer Allowance).

In our sample, $8.1 \%$ of respondents are defined as informal carers. In addition, caregiving is divided almost equally between residents (4.1\%) and non-residents (4.0 \%). By gender, females are more likely to report being caregivers $(9.9 \%)$ than males $(6.3 \%)$. More than a half (53\%) of caregivers identified themselves as the main caregiver, with more females (59 \%) than males (43 \%) identifying as such. In addition, caregivers are much more likely to indicate that they are the main caregiver when they co-habit with the care recipients (74\%) than when they do not co-habit with them (33\%).

[Table 1 about here]

The data in Table 1 also show that most care (in total, approximately $89 \%$ ) is provided to immediate family members (spouse/partner: $16 \%$, parents (own or in-law): $51 \%$; or children: 22 \%). In addition, much more care is provided for immediate family members in residential (approximately $97 \%$ ) than non-residential care (approximately $81 \%$ ). Care provided by residential caregivers is distributed fairly evenly between the partners, parents and children. By contrast, most care provided by non-residential caregivers is provided to parents $(77 \%)$.

\subsection{Caregiving transition}

Table 2 presents data on caregiving states, disaggregated by gender and by our two indicators of caregiving intensity: Panel A of Table 2 classifies caregivers according to whether they reside with the people they care for and Panel B classifies caregivers according to whether or

\footnotetext{
${ }^{9}$ While this is not well modelled in extant informal care theories, we borrow from labour supply theory here: individuals choose between providing care or not then, conditional on providing care, individuals decide the intensity of care provision. Empirical models also distinguish intensity of care where possible (Carmichael and Charles, 2003; Lilly et al., 2010; Nguyen and Connelly, 2014). Whether or not the decision to provide care as a primary or secondary carer, contingent on the need for care, is a "choice"-in the traditional sense-is another question that, unfortunately, is largely philosophical, because the datasets that have been available to conduct research of the kind reported here do not contain information that could be used to test hypotheses of this kind. Indeed, it is likely that different data-likely collected using qualitative and/or psychometric methods-would be required to explore hypotheses in respect of care "choices", in the usual sense of this term as used in economics.
} 
not they are classified as the main, or a secondary caregiver. The rows in Table 2 show previous caregiving states and the columns of the table present subsequent caregiving states. The data in both Panel A and Panel B show a strong degree of observed inertia among noncarers since approximately $96 \%$ (97\%) of female (male) non-caregivers in the previous year remained non-carers in the current year. We do, however, observe significant transitions among the caregiving states for caregivers. In particular, for females, while most of the resident caregivers resumed their caregiving role in the subsequent year (65\%), $32 \%$ of them became non-carers, and $2.3 \%$ switched to providing care for non-residents. Also, for females, non-resident caregiving appears to be less stable as only about $48 \%$ remained in their previous caregiving role while $50 \%$ became non-carers. The same transition pattern is observed for males. However as compared to female caregivers, a higher proportion of male caregivers became non-carers in the subsequent year: $39 \%$ who reported being residential caregivers and $65 \%$ who reported being non-residential caregivers in the previous period became non-caregivers in the subsequent period.

[Table 2 about here]

When care intensity is measured according to the main or secondary caregiving roles, we also observe the highest level of inertia among non-caregivers, followed by those classified as the main caregivers and secondary caregivers. As compared to the resident/non-resident care classification, with this care intensity classification we observe qualitatively similar proportions of caregivers becoming non-carers and lower proportions of caregivers resuming their caregiving roles in the subsequent year (male secondary caregivers are the exception). The lower proportions of caregivers resuming their caregiving roles in the subsequent year are consistent with the observation that more previous caregivers switched between the main and secondary caregiving roles in the subsequent year. These descriptive data on transitions between caregiving states appear to be large enough for us to proceed to empirical models of caregiving dynamics in order to make statistical inferences on the dynamics of caregiving intensity.

\section{Empirical model and econometric method}

\subsection{Theoretical background of care provision dynamics}

There are theoretical reasons to characterise informal care provision as an intrinsicallydynamic process. Some theoretical work (Hiedemann and Stern, 1999; Engers and Stern, 2002; Byrne et al., 2009; Rainer and Siedler, 2009) in the long-term care literature uses game 
theory to model the interaction between siblings who make decisions about long-term care for their elderly parents. If the stages of decisions are viewed as sequential, as opposed to simultaneous, these theoretical models imply that decisions to provide care are made dynamically (Fevang et al., 2012; Skira, 2015). As discussed in Sovinsky and Stern (2016), there are several other scenarios where previous care status is taken into account when future care provision decisions are made. For example, the costs associated with changing care arrangements may cause the current caregivers to continue to provide care in the future. In addition, the human capital associated with providing care may cause current caregivers to resume their caregiving roles in the next period because the longer they provide care, the better they become at doing so (due, e.g. to the accumulation of care-specific human capital). Alternatively, individuals who choose to provide care at some point may also have to leave work or reduce the hours worked as a consequence, and may face a lower probability of obtaining jobs offers in the next period due to labour market human capital depreciation (Skira, 2012). Finally, the existence of a "burnout" effect experienced by caregivers who provide care for a long period of time could cause them to exit providing care in the future (Seltzer and $\mathrm{Li}, 2000$ ). These theoretical grounds suggest that the sign of the state dependence in care provision could be positive or negative: thus, its determination is an empirical matter.

\section{2. $\quad$ Econometric models}

The outcome rules for the decisions to work and to care may be written, following Michaud et al. (2010), as follows:

$$
\begin{aligned}
& L_{t}=I\left(U_{L}\left(L_{t-1}, C_{t-1}, Z_{t}, X_{t}\right)>0\right) \\
& C_{t}=I\left(U_{C}\left(L_{t-1}, C_{t-1}, Z_{t}, X_{t}\right)>0\right)
\end{aligned}
$$

where $L_{t}$ and $C_{t}$ represent the decisions to work and to care, respectively, at time $t$; and $U_{L}$ and $U_{C}$ are the utility differences between working and not working, and caring and not caring, respectively. Note that both of these functions include past work and past care decisions, as well as an index, $Z_{t}$, of the demand for care from the potential care recipient at time $t$, and $X_{t}$, which represents the characteristics of the potential caregiver at time $t$. Note that, technically, the resulting reduced form equations that are estimated represent an approximation to the solution of a dynamic model (Keane and Wolpin 2002). ${ }^{10}$

\footnotetext{
10 It would be better to model labour market and informal care giving activities simultaneously as some theoretical models suggest (Keane and Wolpin 2002). However, doing so requires one to find enough plausible instruments to identify the systemof the labour supply and care giving equations. In particular, one needs to find at least two instruments: one instrument that only affects the labour supply equation and the other one that only
} 
In our empirical model, caregiving status is defined by $J$ mutually exclusive states $(J=3)$. The latent value for care status $j$ of individual $i$ at time $t$ is presented as:

$$
C_{i j t}^{*}=X_{i j t} \beta_{X j}+\gamma_{j} C_{i j t-1}+L_{i j t-1} \beta_{L j}+\varepsilon_{i j t}
$$

where $X_{i j t}$ is a vector containing individual observed characteristics with unknown parameters $\beta_{X j}$. We follow the prior literature (Stern, 1995; Mentzakis et al., 2009; Carmichael et al., 2010; Michaud et al., 2010) and use previous labour market states $\left(L_{i j t-1}\right)$ as explanatory variables in an attempt to limit the prospect of the endogeneity of labour market status in the caregiving equations. As discussed earlier, the inclusion of past care status $\left(C_{i j t-1}\right)$ allows past caregiving choices to affect current caregiving choices, thus reflecting the true dynamic characteristics of care provision (Dostie and Léger, 2005; Mentzakis et al., 2009; Michaud et al., 2010; Gardner and Gilleskie, 2012). Individualspecific time-variant unobserved heterogeneity such as preferences over caregiving and labour market attachment are captured by $\epsilon_{i j t}\left(\epsilon_{i j t}=\alpha_{\mathrm{ij}}+\mathrm{u}_{\mathrm{ijt}}\right)$, in which $\mathrm{u}_{\mathrm{ijt}}\left(\alpha_{\mathrm{ij}}\right)$ is time(in)variant unobserved heterogeneity.

As we are estimating dynamic models, we need to deal with the initial conditions problem. The initial conditions problem arises because the caregiving states that arose before the first observed time period in the panel cannot be known and because the state observed in the initial time period $(t=1)$ cannot be assumed to be random. Rather, it is likely that nonrandom unobservable factors are correlated with the initial caregiving states. To account for the initial conditions problem, we follow Wooldridge (2005) and include among our explanatory variables a vector of $(J-1)$ binary dummy variables indicating initial caregiving status $\left(C_{i 1}\right)$ and the average over the sample period of the exogenous time-varying variables $\left(\bar{Z}_{i}\right){ }^{11}$ Although Wooldridge (2005) calls for the inclusion of the initial status of care provision (the dependent variable), we follow the prior literature in this field (Michaud et al., 2010; Kohn and Liu, 2013) and include the initial labour market states in our specification. Specifically, we specify the distribution of the unobserved individual effects as:

influences the informal caregiving equation. Unfortunately, we could not find enough suitable/plausible instruments in our dataset to do that. Studies in the current literature have reported the same difficulties in finding plausible instruments to identify such a system. Therefore, the extant studies (Stern, 1995; Mentzakis et al., 2009; Carmichael et al., 2010; Michaud et al., 2010) usually estimate the reduced form equations of the informal caregiving status as we have done in this manuscript.

${ }^{11}$ An alternative to the Wooldridge (2005) approach is the Heckman's reduced form approximation (Heckman, 1981). Heckman's approach is computationally more demanding than Wooldridge's so we apply the latter. In addition, Arulampalam and Stewart (2009) and Akay (2012) show that Wooldridge's method performs equally well or even better than the Heckman's reduced form approximation method, especially when the duration of the panel is longer than five waves (as is ours). 


$$
\alpha_{i j}=\varphi_{j 0}+C_{i j 1} \varphi_{j 1}+L_{i j 1} \varphi_{j 2}+\bar{Z}_{i j} \varphi_{j 3}+\eta_{i j}(i=1, \ldots, N ; j=2, \ldots, J)
$$

where $\eta_{i j}$ is a new unobserved time-invariant individual effect that is assumed to be multivariate normally distributed and independent of all the explanatory variables and the initial caregiving state. Because this initial caregiving state starts our seven-year time-series, the estimates of $\varphi_{1}\left(\varphi_{2}\right)$ also indicate the medium-term persistence of caregiving (labour market states). Note that using the Wooldridge method, which includes the average of the exogenous time-variant variables, we can also deal with the possible correlation between the exogenous variables and unobserved individual-effects (Mundlak, 1978; Chamberlain, 1980). Using the Wooldridge method thus helps to further limit the likelihood that previous labour market states are endogenous in these care dynamics models. Substituting Equation (4) into Equation (3) we get the augmented specification which accounts both for the initial conditions and unobserved heterogeneity.

The observed caregiving status is denoted by $C_{i j t}$. The individual $i$ chooses the care status $j$ at time $t$ if and only if $C_{i j t}^{*}>0$ (i.e. $C_{i j t}=1\left(C_{i j t}^{*}>0\right)$ ). Since we assign caregivers who provide both residential and non-residential care as the residential caregivers, each individual in our sample therefore can choose only one of three mutually exclusive and collectively exhaustive states $(J=3)$ : non caregiver, resident caregiver, and non-resident caregiver. We therefore can use the Multinomial Logit (MNL) model to model individual choices to provide informal care. For identification purposes, we set the state $j=1$ (non-caregiver) as the base group. All other sets of unknown parameters are estimated in comparison with this base group. $^{12}$ Our dynamic MNL model with random effects is estimated via a maximum simulated likelihood (MSL) method using 50 Halton draws for each individual (Train, 2003). ${ }^{13}$

The empirical approach employed here thus controls for random intercepts with timeinvariant components and initial conditions. We also experiment with two empirical model specifications: Specification I which does not allow for correlation between errors in two care outcome equations and Specification II which does. We apply these two specifications to three alternative models: a baseline model (Model 1) which includes previous labour market

\footnotetext{
12 Note that our dynamic MNL model with random effects does not exhibit the restrictive assumption of Independence of Irrelevant Alternatives (IIA) (Revelt and Train, 1998).

13 We use the mixlogit command in Stata to estimate the model (Haan, 2006). As a robustness check, we increased the number of draws from 50 to 100, but this did not change the results appreciably.
} 
states as defined above and Model 2 (3) which includes variables explaining the work security and flexibility perceptions (overall work satisfaction perceptions).

\subsection{Explanatory variables}

In our model, respondents' characteristics that are associated with the decision to provide care include age (and age-squared), education, marital status and health status. ${ }^{14}$ Furthermore, we use non-labour income and home ownership status to control for any wealth effect on the respondent's care provision decisions. Non-labour income is the sum of the respondent's income from sources other than wages, salaries, business income, private pensions, and includes the other members' income from all sources. This non-labour income is normalized by the square root of household size to adjust for economies of scale in consumption. Home ownership is reflected by a dummy variable that indicates whether or not the home that the respondent is living in is owned or its mortgage is currently being paid off by any member of the household. ${ }^{15}$ As the country of origin may also play some role in explaining caregiving decisions, we also include two dummy variables in all equations for immigrant status. These dummy variables reflect whether or not the respondent is an immigrant, and also whether immigrants emigrated from an English-speaking background (ESB) or a non-English speaking background (NESB). ${ }^{16}$ We further disaggregate the NESB group by distinguishing northern/western Europe from the rest of NESB countries. We additionally include a dummy variable that indicates when an individual migrated to Australia as a child which would make them more likely to have parents in Australia. ${ }^{17}$ Household characteristics in the models also include the number of co-residing members of various age cohorts. We also control for differences in working conditions and formal care across regions by including the regional unemployment rate, regional relative socio-economic advantage index, state dummies and a rural/urban dummy in the caregiving equations. In addition, throughout the empirical analysis, we include a full set of year dummies to control for fluctuations in the formal care or labour markets over time.

\footnotetext{
${ }^{14}$ We do not include work experience which is measured in years the respondent has spent at all paid jobs since this variable entails a lot of missing information. See Appendix Table A1 for variable description and summary statistics.

${ }^{15}$ We cannot include total net wealth in our model since information on family wealth such as assets and liabilities are not available for every wave.

${ }^{16}$ We also experimented with including indigenous/non-indigenous status in the regression. For males, the estimation of this variable is very imprecise (i.e. it has large standard errors), suggesting a small number of observations having this characteristic. This variable is not significant in all regressions for females. We therefore decided to drop it from the final specification.

${ }^{17}$ We thank an anonymous referee for this suggestion.
} 
We also include variables that may affect the demand for care such as the health status of potential care recipients (any serious personal injury/illness of a relative or family member) or the death of a family member (spouse/children/relative) or a close friend. ${ }^{18}$ These variables represent demand-shifters for care for both residents and non-residents. ${ }^{19}$

As discussed above, we also include a vector of previous labour market states in the care dynamics equations. We distinguish between four different labour market states: full-time employment, part-time employment, self-employment and economic inactivity (the benchmark group). Previous research has shown that work characteristics typically differ according to the nature of employment (Henz, 2006; Origo and Pagani, 2009). Our data, which contain respondents' various self-reported opinions about their jobs also show that the three types of employment (full-time, part-time and self-employment), do indeed differ in terms of job security, flexibility and benefits. ${ }^{20}$ See Appendix Table A3 for details. Appendix Table A4 also shows that full-time employment is perceived to offer the highest level of job security and the most generous workplace entitlements ${ }^{21}$ (as measured by all variables describing the respective work characteristics), followed by part-time employment and selfemployment. By contrast, self-employment offers the highest level of work flexibility, following by part-time and full-time employment has the lowest. Our classification of labour market status thus captures job security, flexibility and benefits reasonably well.

Work security and flexibility is then captured directly by using self-reported indicators of job security and flexibility. Job security, which measures the probability that an individual will keep his or her job, theoretically may affect the decision to provide care in two different (and opposite) ways. It may be that individuals with a lower level of work security would be more likely to provide care because they face a lower opportunity cost in the labour market (Hyslop, 1999; Skira, 2015) (e.g., they may be more likely to be unemployed). Conversely,

\footnotetext{
${ }^{18}$ We aggregate deaths of spouses, children and relatives because these are rare events in our dataset.

${ }^{19}$ Unfortunately, the panel does not include data that would enable us to control for other factors that may have an impact on the decision to provide care, such as whether the respondent's parents are still alive, geographical distance to parents, the number of siblings or the availability of formal care.

${ }^{20}$ Like work status, work characteristics are likely to be endogenous in the caregiving equations. We therefore employ the two strategies (i.e. including the lag of work characteristics and controlling for unobserved heterogeneity via estimating an MNL model with random effects) that were applied for work status per se, to address the possible endogeneity of work characteristics in the caregiving equations.

${ }^{21}$ While access to workplace benefits such as special leave for caring for family members or paid maternity leave would have an impact on workers' decision to provide care, we do not include a measure of workplace benefits in our model because all available workplace benefit measures entail a lot of missing information. In our sample, in each wave, about $20 \%$ of respondents who were asked the relevant work place benefit questions responded "Don't know". Since we use a balanced panel sample, if we were to include these work benefit variables in our models, this would give rise to pair-wise observation dropping, causing a significant loss ( $>20$ $\%$ of the original sample) of data.
} 
individuals with lower job security may be more resistant to taking on a caregiving role precisely because they may be at greater risk of losing and of not regaining employment. To our knowledge, the impact of job security on care provision has not been empirically analysed in the extant literature on informal care. Following Bryan (2012) and Henz (2006), we include variables representing workplace flexibility in our regressions. Unlike these previous studies, though, which use concurrent work characteristics and care decisions, we use respondents' responses to questions about the flexibility of their workplaces as indicators of the latent flexibility of the workplace, and measure the effects of these on subsequent care choices. Specifically, we use responses to a "job security satisfaction" question to represent work security and responses to a "the flexibility to balance work and non-work commitments satisfaction” question to proxy for work flexibility for three reasons. ${ }^{22}$ First, these variables are highly correlated with the other measures of work security and flexibility that are available to us (See Appendix Table A3). Second, questions about "job security satisfaction" and "work and life job satisfaction" were asked for all employed individuals, including selfemployed people, so we do not need to impute information for self-employed individuals. Third, these measures entail much less missing information than the alternatives. Finally, in addition to these two measures of work security and flexibility, in separate regressions, we also include a measure representing "overall job satisfaction" in our model because this measure is also highly correlated with work security and flexibility measures (see Appendix Table A3).

Unemployed individuals obviously were not asked the foregoing questions. Following the usual practice in the literature dealing with missing information, we use a "dummy variable adjustment" method. This method has been proven to be appropriate for cases where the unobserved value simply does not exist (Allison, 2001, footnote 5). In our case, job characteristics of unemployed individuals do not exist. We implement this method by substituting the variable's mean for all missing cases. ${ }^{23}$ In addition, we include a dummy

\footnotetext{
${ }^{22}$ In particular, respondents were told: "I now have some questions about how satisfied or dissatisfied you are with different aspects of your job. If not currently employed: These questions refer to the most recent job you were working in the last 7 days. I am going to read out a list of different aspects of your job and, using the scale on SHOWCARD E36, I want you to pick a number between 0 and 10 to indicate how satisfied or dissatisfied you are with the following aspects of your job. The more satisfied you are, the higher the number you should pick. The less satisfied you are, the lower the number".

${ }^{23}$ We dropped individuals (about $3 \%$ of the original balanced panel sample) who were employed or selfemployed but had missing information on these variables rather than using the "dummy variable adjustment" method because deletion has been found to produce less biased estimates (Allison, 2001). We use the variable's mean for the job characteristic variables of unemployed people for ease of interpretation of the unemployed dummy variable as suggested by Allison (2001). The results for work characteristic variables were identical when we assigned the lowest value $(=0)$ of work characteristic variables for unemployed individuals.
} 
variable coded 1 if the original variable is missing and 0 otherwise. This dummy variable is also the variable used to describe unemployment status. Thus, estimates of work characteristic variables can be interpreted as the effect of, say, work security perceptions given that the individuals worked last year; whereas the variable "unemployed last year" distinguishes between individuals who did not work last year and had average work security perceptions and individuals who worked last year and also had average work security perceptions.

\section{Empirical results}

In this section, we present the estimation results from the dynamics models of care provision when care intensity is defined by residency status (sub-section 5.1) and the main/secondary roles (defined in sub-section 5.2). Within each sub-section, we discuss the results from some model specification tests, following by main results from three alternative models (model 1 with employment status, model 2 with work security and flexibility indicators, and model 3 with overall work satisfaction indicators). We also discuss other factors affecting the optimal choice over caregiving at the end of each sub-section.

\subsection{Resident versus non-resident care}

\subsubsection{Test results}

We first discuss the results obtained for the dynamics of care provision when care intensity is defined by residency status between the caregiver and care recipient (Table 3a). The standard deviations (SD) of the individual random coefficients which are reported at the lower part of Table 3a indicate that unobserved heterogeneity is important in all regressions: they are all highly statistically significant. The correlation between errors in the two care outcome equations is also reported at the lower part of Table $3 \mathrm{a}^{24}$ The correlation coefficient is negative and statistically significant for males only. This negative correlation suggests that, for males, unobserved characteristics that make them more likely to provide non-resident care also make them less likely to provide other care. For males, the inclusion of the correlation

\footnotetext{
${ }^{24}$ While there are three alternatives (non-caregiver, resident caregiver and non-resident caregiver), for identification purposes, the MNL model only estimates two equations: resident caregiver (versus non-caregiver) and non-resident caregiver (versus non-caregiver). As such, there is only one correlation in errors of the resident caregiver and non-resident caregiver equations is estimated and reported.
} 
between errors also improves the fit of the model as measured by the Likelihood Ratio (LR) test for the error covariance matrix. ${ }^{25}$

[Table 3a about here]

We use the Akaike Information Criterion (AIC) (Akaike, 1973) and the Bayesian Information Criterion (BIC) (Schwarz, 1978) to assess the fit for two specifications. Both criteria aim to weight the model fit and the number of parameters, with lower values of the BIC and the AIC indicating preferred models. These model selection criteria, reported at the bottom of Table 3a, favour Specification I for females. By contrast these two model selection criteria are in disagreement with respect to the preferred specification of error correlation: the AIC suggests that Specification II is preferred while BIC, which imposes a greater penalty for model complexity, suggests Specification I. In any event, note that that accounting for error correlation does not change the significance of any of the parameter estimates appreciably for either males or females.

\subsubsection{Main results}

The results in Table 3a show that, for both females and males, providing care to residents rather than providing care to non-residents or providing no care in the previous year increases the probability of providing care for residents in the subsequent year. ${ }^{26}$ Similarly, providing care to non-residents rather than providing care to residents or providing no care last year increases the probability of providing care for non-residents this year. These results confirm the existence of significant positive state-dependence in care status for both males and females. Comparing the persistence of resident and non-resident care, we observe that

\footnotetext{
${ }^{25}$ The (joint) significance of the error correlations can be tested using an LR test. The test statistic, which is Chisquared distributed with $\mathrm{k}$ degrees of freedom ( $\mathrm{k}=$ number of error correlation $=1$ in our case) is given by $2^{*}$ (Log Likelihood of Specification II - Log Likelihood of Specification I).

${ }^{26}$ We focus on the direction of the impact in this paper. However, to get a sense about the magnitude of the estimates we report the average marginal effects (AMEs) for main variables (i.e., care provision and labour market states). The AMEs, which are expressed as percentage-point differences, were computed by simulating, for each individual in the sample, the probability of providing care for a particular state before and after a change in the relevant characteristic and then averaging those probabilities over time and over individuals. The interpretation of the AMEs is as follows: an AME of 4.99 for the variable "resident care last year" (first row in Table 3a) from the female resident care equation (first column) suggests that providing care for residents the previous year increases the probability of providing care for residents in the subsequent year by 4.99 percentage points. Theoretically, we can use a bootstrapping technique to get the standard errors (and hence the statistical significance level) of AMEs. However, it is impractical to do so because we have to run each regression at least 100 times to get a reasonably reliable estimate of standard errors. In our case, running one regression takes more than 6 hours. We therefore assign the statistical significance level of the coefficient estimates to the AMEs. We also follow Michaud et al. (2010) to simulate the dynamic effects of care and report the results in Appendix Table A12 (for resident/non-resident care) and A13 (for main/secondary care). Consistent with evidence provided in the previous UK study by Michaud et al. (2010), our results also suggest the AMEs tend to zero within 3 years.
} 
resident care is more persistent than non-resident care, a finding which is consistent with the U.K. evidence presented in Michaud et al. (2010).

The presence of state-dependence in care provision is also found in the medium-term. The estimates of variables describing initial care states (measured in 2005) show that male and female individuals who provided care for residents (non-residents) at the beginning of the study period were more likely to provide care for residents (non-residents) in the subsequent year. For females, we do not observe switches between caregiving for residents and nonresidents during the study period. For males, though, we do observe switches between caring for residents and non-residents. Specifically, males who started the study period as resident (non-resident) caregivers are more likely to become non-resident (resident) caregivers in the subsequent year. Our finding of the evidence of switching between caring for residents and non-residents for Australian males is in line with evidence presented in Michaud et al. (2010) for U.K. females. Our results, however, suggest that while inertia in care provision does exist for both females and males, it appears to be longer lasting for males. Again, in our study, resident care appears to be more persistent than non-resident care in the medium-term for both males and females.

We next turn to the impact of previous employment states on current care decisions. Results from Specification I in Table 3a show that, for females, only working on a full-time basis last year statistically significantly reduces the probability of providing care (either for residents or non-residents) this year. Working in other capacities (i.e. in part-time or self-employment) in the previous year does not, however, have any apparent impact on decisions to provide care either for residents or non-residents in the current year. Our findings of heterogeneous impacts of previous work status on current care provision decisions suggest that the deterrent impact of previous work status--as identified by working or not on current care decisions that has been found in the literature (Mentzakis et al., 2009; Carmichael et al., 2010; Michaud et al., 2010)--may be concentrated among full-time employed females (only). ${ }^{27}$ By contrast, for males (results from Specification I and II in Table 3a), working on any basis last year strongly statistically significantly decreased the probability of providing care to residents in the subsequent year. Males' previous work states, however, do not have any statistically

\footnotetext{
${ }^{27}$ We experimented with defining previous work status by one dummy variable (i.e. working or not) as used in the prior studies (Mentzakis et al., 2009; Carmichael et al., 2010; Michaud et al., 2010). Results from this experiment show that, for females, working last year only marginally (at the 10 per cent level of statistical significance) statistically decreases their probability of providing care for residents this year. In addition, also for females, working last year does not have any statistically significant impact on the probability of providing care for non-residents this year.
} 
significant impact on their decisions to provide care to non-residents in the current year. Similarly, for both males and females, initial work status (which is measured in 2005 in our data) has a statistically insignificant impact on current decisions to provide care. Males who worked part-time in 2005 are the exception: they are less likely (at the $5 \%$ level) to provide care for non-residents in the current year.

\subsubsection{Results from alternative models with work characteristics}

Above we found heterogeneous impacts of previous employment states on current care provision decisions. As discussed earlier, these heterogeneous impacts may reflect the different work characteristics associated with different types of employment. In this section, we directly examine which previous work characteristics are driving working respondents to provide informal care in subsequent years. We discuss the results from two alternative models with direct measures of work characteristics. Results from Model 2, which includes indicators representing work security and flexibility perceptions, and Model 3, which controls for overall work satisfaction perceptions, are reported in Table 3b and 3c, respectively. The test statistics and coefficient estimates in Model 2 and 3 are remarkably similar to those presented previously for Model 1 . The only noticeable differences are that, for both males and females, estimates of the variable explaining the "unemployed" status become statistically insignificant in all specifications and models. The insignificant estimates for this variable suggest that there is no difference between the previously employed and unemployed individuals regarding choices to provide care either for residents or non-residents in the subsequent years. Estimates for the "unemployed" variable for males in Model 3 are the exception: males who were unemployed last year are marginally more likely (at the 10 per cent level) to provide care for residents in the subsequent year than their employed counterparts. As discussed in section 4.2, it is possible that the effects of the three types of employment (i.e. full-time, part-time and self-employment) differ but that their combined impact is to cancel out.

Controlling for previous work status, we find that, for previously employed males and females, work security, flexibility and overall work satisfaction perceptions have no statistically significant impact on subsequent decisions to provide care (either for residents or non-residents). Estimates on our indicator of job security perceptions (which were measured at the beginning of the study period) are, however, negative and statistically significant at the 5 per cent level in the non-resident care equation for males. Taken at face value, these estimates suggest that among males working in the initial year, those who perceived a lower 
level of job security were actually more likely to provide care for non-residents in the current year.

[Table 3b and 3c about here]

\subsubsection{Other results}

We next discuss other factors that may affect the optimal choice over caregiving (Appendix Table A6). Most of the estimates are as expected. In particular, migrant background plays a statistically significant role in explaining the caregiving decisions of males only. Specifically, male immigrants from NESB countries outside the northern/western Europe are more likely to provide care for non-residents than male Australian-born individuals. In our data, parents represent more than three quarters of non-resident care recipients and about half of male immigrants are from Asia. Therefore, our finding of a higher probability of providing among immigrants from NESB countries outside the northern/western Europe is consistent with an often-observed pattern that children, especially sons, are main sources of informal support for their elderly parents in Asian countries (Cai et al., 2006; Cameron and Cobb-Clark, 2008; Nguyen et al., 2012). Among immigrants, we also observe a higher incidence of caregiving (by females (for non-residents) and males (for residents or non-residents)) among those arrived in Australia as a child, probably because they are likely to be linked with closer physical contact with their relatives or friends.

We also find the probability of being the resident caregiver decreases with higher educational attainment (bachelor's degree or higher). While the signs of these coefficients are consistent with the observation that people with higher education may tend to face higher opportunity costs of providing care (Norton, 2000), the results are statistically significant for males only. Appendix Table A6 also shows that, as compared to females living in a rented home, those living in an outright-owned home are more likely to provide care to residents, a finding which suggests that more stable housing, as measured by outright home ownership, could facilitate care provision for residents.

Characteristics of co-habiting household members also correlated with the respondent's care provision decisions. The probability of providing care as a resident caregiver, for instance, significantly increases for males and females who live together with older family members. As expected, caregivers who live with older household members are statistically significantly less likely to provide care to non-residents since they have to provide care to residents in need. This estimated impact is, however, statistically significant only for males. 
We also observe that indicators of the health status of potential care recipients significantly affect the respondents' care provision decisions. For both males and females, any recent serious injury or illness of a family member statistically significantly increases the probability of providing care for either residents or non-residents. By contrast, the death of a relative statistically significantly reduces the probability of providing care for non-residents only. The death of a close friend however does not have any statistically significant impact on the probability of providing any type of care.

\subsection{Main versus secondary caregivers}

\subsubsection{Test results}

We next discuss results from dynamic models of the intensity of care provision (i.e. through main and secondary care provision). The main results are reported in Table 4a. The lower panel in Table 4a shows that the correlation coefficients are positive and highly statistically significant for males and females. These positive error correlations suggest that unobservables that increase an individual's probability of providing care as the main caregiver also affect his or her probability of supplying care as a secondary caregiver, in the same direction. The significance of the estimates of error correlations also suggests a higher level of inertia of care intensity as defined by the main or secondary caregiving roles if the correlation between errors is ignored. This correlation of the errors also changes the statistical significance of some estimates for males. For example, the parameter estimate on the "main carer last year" variable in the secondary care regression is statistically significant (at the 5 per cent level) in Specification I, which does not account for error correlation, to statistically insignificant in Specification II, which does account for the correlation of the error terms. Similarly, the estimate for the "secondary care last year" variable in the main care equation changes from being highly significant (at the 1 per cent level) to marginally significant (at the 5 per cent level) in the regressions that control for error correlation.

[Table 4a about here]

The highly statistically significant estimates of error correlation also help to explain why, in most cases, the AIC and BIC support Specification II. An exception is observed for males (in Model 1) where the BIC marginally favours Specification I.

\subsubsection{Main results}

Results from the regressions with an error correlation structure (Specification II - Table 4a) suggest a lower propensity of transition between care intensity roles for males than for 
females. Specifically, for females, providing care as a main (secondary) caregiver last year statistically significantly increases the probability of providing care as a secondary (main) caregiver this year. By contrast, for males, providing care as the main (secondary) caregiver has no statistically significant impact on the probability of supplying care as a secondary (main) caregiver. This is, however, the only apparent gender difference in the estimates of past care status on current caregiving status that we observe. For other estimates, we observe a similar pattern of care inertia for both males and females. Specifically, males and females providing care as main or secondary caregivers last year are statistically significantly more likely to resume those roles in the current year. ${ }^{28}$ Similarly, individuals who provided care (either as main or secondary caregivers) at the beginning of the study period (i.e. in 2005) are more likely to provide care either as main or secondary caregivers in the current year.

Turning to the impact of previous employment status on current caregiving decisions, we also observe heterogeneous impacts by gender. For females, only those working on a full-time basis in the previous year are less likely to provide care either as main or secondary caregivers in the subsequent year. By contrast, for males, working on any basis (full-time, part-time or self-employment) in the preceding year statistically significantly reduces the probability of providing care as main caregivers in the subsequent year. However, males' previous working states do not statistically significantly affect their subsequent decisions to provide care as secondary caregivers. Males who worked part-time last year are the exception: they are more likely to provide care as secondary caregivers in the subsequent year, probably as a result of an interaction between various work security, flexibility and benefit characteristics that we will discuss in Sub-section 5.2.3. Additionally, only working on a part-time or self-employed basis in the initial year (i.e. 2005) statistically significantly reduces males' chance of assuming a secondary caregiver role in the subsequent year. This finding is likely to be due to individuals changing their employment status to full-time employment in the subsequent year.

\footnotetext{
${ }^{28}$ It is likely that switching between main and secondary caregiving roles is more feasible when individuals live with their partners, given that care is often provided for elderly parents and children. To test this possibility, we experimented with including interaction terms between one-year lags of main and secondary caregiving variables and the individual's marital status and test for the statistical significance of these interaction terms. We use the individual's marital status to indicate the presence of the individual's partner because almost all married individuals co-reside with their partners in our sample. The results from this experiment indicate some evidence of such a possibility for males only. Specifically, the presence of a male individual's partner is found to statistically (at the $5 \%$ level) increase the probability of switching from the main caregiving roles last year to secondary roles in the current year. We thank an anonymous reviewer for suggestions that led us to conduct this experiment. The results from this experiment are available upon request.
} 
In summary, the results from two alternative classifications of care provision both confirm the presence of significant state-dependence in informal care provision for both males and females. This finding is consistent with the observation that caregivers are more likely to identify themselves as the main caregiver when they provide care for residents (see Table 1). The pattern of state-dependence from two different classifications of care provision, however, appears to be more similar for males than for females. Disaggregation by care intensity (i.e. main or secondary caregiving roles) further reveals that females providing care as main (secondary) caregivers last year are more likely to provide care as secondary (main) caregivers this year. Recall that classifying care by residency status, we did not find evidence that females switched from providing care to residents to providing care to non-residents, or vice versa. These differences in the estimates between the two care definitions for females may reflect the differences in the types of care recipients to whom males and females provide care. It is also possible that, as previously found in this literature (Lilly et al., 2010; Nguyen and Connelly, 2013), males and females apply different measures of care intensity. While the results here confirm the previous evidence of inertia in care provision, they may also suggest a certain level of "flexibility", especially for females, in care provision. Specifically, caregivers who find it hard to exit their caregiving duties may be able to adjust the intensity of care by switching between the main and secondary caregiving roles.

\subsubsection{Results from alternative models with work characteristics}

Results from models with indicators of work security and flexibility (overall job satisfaction) perceptions are reported in Table 4b (4c). The parameter estimates for most variables are almost identical to those found in Model 1, as are the test statistics.

[Table 4b and 4c about here]

Controlling for working status, we find that work flexibility perceptions have no impact on workers' subsequent care decisions (See Table 4b). By contrast, for both male and female workers, perceptions about job security do influence their subsequent decisions to provide care. It is interesting to observe that while job security perceptions influence males' and females' subsequent decisions to provide care in the same direction they take longer to have an impact on males' care provision decisions. In particular, among females who worked last year, those who felt their jobs were more secure are less likely to provide care as main caregivers this year. By contrast, only males who worked in 2005 and perceived their jobs more secure are less likely to provide care (either as main or secondary caregivers) in the 
current year. Our finding of a different impact of job security perceptions by time horizon for males and females is thus consistent with a stronger labour market attachment for males than females.

Turning to the impact of overall job satisfaction perceptions on care provision decisions, we also find a medium-term impact for male workers. Specifically, results from Table 4c suggest that males who worked in 2005 and reported higher overall job satisfaction are less likely to provide care as main caregivers in current year. This is, however, the only statistically significant impact of job satisfaction perceptions that we observe in Model 3.

\subsubsection{Other results}

Consistent with the observation that caregivers are more likely to identify themselves as the main caregiver when they co-reside with care recipients, estimates for other variables (reported in Appendix Table A9) are almost the same as those found previously when care is distinguished by residency status. One noticeable change is that, for both males and females, the estimated coefficients on variables that describe the number of co-residing members of various age cohorts become statistically insignificant in both the main and secondary care equations. This is reasonable because these variables represent the characteristics of those who live with the caregivers and they are expected to be more closely related with the demand for care as defined by residency status.

\section{Conclusion}

We have examined the dynamics of care provision by working age Australians. Our multinominal dynamic models account for state-dependence, unobserved heterogeneity and initial conditions. The results provide strong evidence of positive state-dependence in all care provision states (defined either by residency status or main/secondary role). This is true in both the short- and medium-term, irrespective of gender. In addition, the persistence in care provision appears to be stronger for more intensive care types (i.e. resident care or main care).

We also find that previous employment states have some significant deterrent impacts on subsequent care decisions. The employment impacts, however, vary by type of previous work, type of current care, and also by gender of the caregiver. In particular, for females, only working on a full-time basis in the preceding year reduces the subsequent probability of providing any type of care (defined either by residency status or intensity). By contrast, for males, working on any basis last year statistically significantly reduces the subsequent 
probability that they provide more intensive care (i.e. resident or main care), only. We additionally find that workers' perceptions about work flexibility or overall work satisfaction have no impact on their subsequent decisions to provide care of any type. From the public policy point of view, our findings of significant inertia in care provision--viewed in the light of earlier evidence that workers with lower skills are faced with longer durations of unemployment (Pissarides, 1992)--suggests that if returning caregivers to work is a policy goal, appropriate training programs or other facilitation of return-to-work may also be needed. 


\section{References}

Akaike, H., 1973. Information theory and an extension of the maximum likelihood principle, In: Petrov, B., Csaki, F. (Eds.), Proceedings of the 2nd International Symposium on Information Theory. Budapest: Akademinai Kiado, pp. 267-281.

Akay, A., 2012. Finite-sample comparison of alternative methods for estimating dynamic panel data models. Journal of Applied Econometrics 27, 1189-1204.

Allison, P.D., 2001. Missing Data. Thousand Oaks, CA: SAGE Publications, Inc.

Arulampalam, W., Stewart, M.B., 2009. Simplified Implementation of the Heckman Estimator of the Dynamic Probit Model and a Comparison with Alternative Estimators*. Oxford Bulletin of Economics and Statistics 71, 659-681.

Becker, G.S., 1974. A Theory of Social Interactions. The journal of political economy 82, 1063-1093.

Berecki-Gisolf, J., Lucke, J., Hockey, R., Dobson, A., 2008. Transitions into informal caregiving and out of paid employment of women in their 50s. Social Science and Medicine 67, 122-127.

Berkovec, J., Stern, S., 1991. Job exit behavior of older men. Econometrica: Journal of the Econometric Society 59, 189-210.

Bernheim, B.D., Shleifer, A., Summers, L.H., 1985. The Strategic Bequest Motive. The journal of political economy 93, 1045-1076.

Borsch-Supan, A., Gokhale, J., Kotlikoff, L.J., Morris, J.N., 1992. The Provision of Time to the Elderly by Their Children, In: Wise, D.A. (Ed.), Topics in the Economics of Aging. Chicago: University of Chicago Press, pp. 109 - 134.

Brown, M., 2006. Informal Care and the Division of End-of-Life Transfers. Journal of Human Resources 41, 191-219.

Bryan, M.L., 2012. Access to Flexible Working and Informal Care. Scottish Journal of Political Economy 59, 361-389.

Byrne, D., Goeree, M.S., Hiedemann, B., Stern, S., 2009. Formal Home Health Care, Informal Care, and Family Decision Making*. International Economic Review 50, 12051242.

Cai, F., Giles, J., Meng, X., 2006. How Well Do Children Insure Parents against Low Retirement Income? An Analysis using Survey Data from Urban China. Journal of Public Economics 90, 2229-2255.

Cameron, L., Cobb-Clark, D., 2008. Old-Age Support in Indonesia: Labor Supply, Intergenerational Transfers, and Living Arrangements. Journal of Population Economics 21, 1007-1033.

Carmichael, F., Charles, S., 2003. The opportunity costs of informal care: Does gender matter? Journal of Health Economics 22, 781-803.

Carmichael, F., Charles, S., Hulme, C., 2010. Who will care? Employment participation and willingness to supply informal care. Journal of Health Economics 29, 182-190. 
Casado-Marín, D., García-Gómez, P., López-Nicolás, A., 2011. Informal care and labour force participation among middle-aged women in Spain. SERIEs 2, 1-29.

Chamberlain, G., 1980. Analysis of Covariance with Qualitative Data. The Review of Economic Studies 47, 225-238.

Couch, K.A., Daly, M.C., Wolf, D.A., 1999. Time? Money? Both? The Allocation of Resources to Older Parents. Demography 36, 219-232.

Cox, D., 1987. Motives for Private Income Transfers. The journal of political economy 95, 508-546.

Cox, D., Rank, M.R., 1992. Inter-Vivos Transfers and Intergenerational Exchange. The Review of Economics and Statistics 74, 305-314.

Cox, D., Stark, O., 1996. Intergenerational Transfers and the Demonstration Effect, Boston College Working Papers in Economics working paper number 329. Chestnut Hill, MA: Boston College.

Dostie, B., Léger, P.T., 2005. The Living Arrangement Dynamics of Sick, Elderly Individuals. The Journal of Human Resources 40, 989-1014.

Engers, M., Stern, S., 2002. Long-Term Care and Family Bargaining. International Economic Review 41, 73 -114.

Ettner, S.L., 1996. The Opportunity Costs of Elder Care. The Journal of Human Resources 31, 189-205.

Fevang, E., Kverndokk, S., Røed, K., 2012. Labor supply in the terminal stages of lone parents' lives. Journal of Population Economics 25, 1399-1422.

Gardner, L., Gilleskie, D.B., 2012. The Effects of State Medicaid Policies on the Dynamic Savings Patterns and Medicaid Enrollment of the Elderly. Journal of Human Resources 47, 1082-1127.

Goeree, M.S., Hiedemann, B., Stern, S., 2012. Will you still want me tomorrow? The dynamics of families' long-term care arrangements. Department of Economics - University of Zurich.

Haan, P., 2006. Estimation of multinomial logit models with unobserved heterogeneity using maximum simulated likelihood. Stata Journal 6, 229-245.

Heckman, J., 1981. The incidental parameters problem and the problem of initial conditions in estimating a discrete time-discrete data stochastic process, In: Manski, C.F., McFadden, D.L. (Eds.), Structural Analysis of Discreet Data with Econometric Applications. Cambridge: The MIT Press, pp. 179-195.

Heitmueller, A., 2007. The chicken or the egg?. Endogeneity in labour market participation of informal carers in England. Journal of Health Economics 26, 536-559.

Henz, U., 2006. Informal Caregiving at Working Age: Effects of Job Characteristics and Family Configuration. Journal of Marriage and Family 68, 411-429.

Hiedemann, B., Stern, S., 1999. Strategic play among family members when making longterm care decisions. Journal of Economic Behavior \& Organization 40, 29-57.

Hyslop, D.R., 1999. State Dependence, Serial Correlation and Heterogeneity in Intertemporal Labor Force Participation of Married Women. Econometrica 67, 1255-1294. 
Kohn, J.L., Liu, J.S., 2013. The dynamics of medical care use in the British household panel survey. Health Economics 22, 687-710.

Lilly, M.B., Laporte, A., Coyte, P.C., 2010. Do they care too much to work? The influence of caregiving intensity on the labour force participation of unpaid caregivers in Canada. Journal of Health Economics 29, 895-903.

Mentzakis, E., McNamee, P., Ryan, M., 2009. Who cares and how much: Exploring the determinants of co-residential informal care. Review of Economics of the Household 7, 283303.

Michaud, P.C., Heitmueller, A., Nazarov, Z., 2010. A dynamic analysis of informal care and employment in England. Labour Economics 17, 455-465.

Mundlak, Y., 1978. On the Pooling of Time Series and Cross Section Data. Econometrica 46, 69-85.

Nguyen, H.T., Connelly, L.B., 2013. Informal care intensity and labour market outcomes: Evidence from instrumental variable panel data models, The HILDA Research Conference, 3 - 4 October 2013, the University of Melbourne, Melbourne.

Nguyen, H.T., Connelly, L.B., 2014. The effect of unpaid caregiving intensity on labour force participation: Results from a multinomial endogenous treatment model. Social Science \& Medicine 100, 115-122.

Nguyen, H.T., Liu, A.Y.C., Booth, A.L., 2012. Monetary Transfers from Children and the Labour Supply of Elderly Parents: Evidence from Vietnam. Journal of Development Studies 48, 1177-1191.

Norton, E.C., 2000. Chapter 17 Long-term care, In: Anthony, J.C., Joseph, P.N. (Eds.), Handbook of Health Economics: Elsevier, pp. 955-994.

Norton, E.C., Nicholas, L.H., Huang, S.S.-H., 2013. Informal Care and Inter-vivos Transfers: Results from the National Longitudinal Survey of Mature Women. The B.E. Journal of Economic Analysis \& Policy 14, 377-400.

Origo, F., Pagani, L., 2009. Flexicurity and job satisfaction in Europe: The importance of perceived and actual job stability for well-being at work. Labour Economics 16, 547-555.

Pavalko, E.K., Henderson, K.A., 2006. Combining Care Work and Paid Work: Do Workplace Policies Make a Difference? Research on Aging 28, 359-374.

Pissarides, C.A., 1992. Loss of Skill During Unemployment and the Persistence of Employment Shocks. The Quarterly Journal of Economics 107, 1371-1391.

Rainer, H., Siedler, T., 2009. O Brother, Where Art Thou? The Effects of Having a Sibling on Geographic Mobility and Labour Market Outcomes. Economica 76, 528-556.

Revelt, D., Train, K., 1998. Mixed Logit with Repeated Choices: Households' Choices of Appliance Efficiency Level. Review of Economics and Statistics 80, 647-657.

Schneider, U., Trukeschitz, B., Mühlmann, R., Ponocny, I., 2013. “Do I stay or do I go?”job change and labor market exit intentions of employees providing informal care to older adults. Health Economics 22, 1230-1249.

Schwarz, G., 1978. Estimating the dimension of a model. The annals of statistics 6, 461-464.

Seltzer, M.M., Li, L.W., 2000. The Dynamics of Caregiving: Transitions During a ThreeYear Prospective Study. The Gerontologist 40, 165-178. 
Skira, M., 2012. Dynamic Wage and Employment Effects of Elder Parent Care: Boston College Working Papers in Economics.

Skira, M., 2015. Dynamic Wage and Employment Effects of Elder Parent Care. International Economic Review 56, 63-93.

Sovinsky, M., Stern, S., 2016. Dynamic modelling of long-term care decisions. Review of Economics of the Household 14, 463-488.

Stern, S., 1995. Estimating Family Long-Term Care Decisions in the Presence of Endogenous Child Characteristics. The Journal of Human Resources 30, 551-580.

Train, K., 2003. Discrete choice methods with simulation. Cambridge: Cambridge University Press.

Van Houtven, C.H., Coe, N.B., Skira, M.M., 2013. The effect of informal care on work and wages. Journal of Health Economics 32, 240-252.

Watson, N., 2012. Longitudinal and cross-sectional weighting methodology for the HILDA Survey. HILDA project technical paper series - Technical paper 2/12.

Wooldridge, J.M., 2005. Simple solutions to the initial conditions problem in dynamic, nonlinear panel data models with unobserved heterogeneity. Journal of Applied Econometrics 20, 39-54.

Zuba, M., Schneider, U., 2012. What Helps Working Informal Caregivers? The Role of Workplace Characteristics in Balancing Work and Adult-Care Responsibilities. Journal of Family and Economic Issues, 1-10. 
Table 1: Caregivers and care recipients

\begin{tabular}{|c|c|c|c|c|c|c|c|c|c|}
\hline & \multicolumn{3}{|c|}{ Resident caregiver } & \multicolumn{3}{|c|}{ Non-resident caregiver } & \multicolumn{3}{|c|}{ "Resident and non-resident caregiver } \\
\hline & Female & Male & Total & Female & Male & Total & Female & Male & Total \\
\hline Carer: \% Yes & 4.7 & 3.5 & 4.1 & 5.2 & 2.8 & 4.0 & 9.9 & 6.3 & 8.1 \\
\hline Main carer: \% Yes ${ }^{(a)}$ & 84.9 & 59.5 & 74.1 & 37.6 & 24.9 & 33.3 & 58.6 & 43.4 & 52.7 \\
\hline \multicolumn{10}{|l|}{ Who is cared for: ${ }^{(a)}$} \\
\hline Spouse/partner & 28.6 & 35.0 & 31.3 & 0.5 & 0.2 & 0.4 & 14.0 & 19.7 & 16.2 \\
\hline Parents & 20.1 & 34.2 & 26.1 & 76.7 & 76.1 & 76.5 & 49.9 & 52.8 & 51.0 \\
\hline Children & 47.3 & 29.0 & 39.5 & 4.5 & 4.5 & 4.5 & 24.8 & 18.1 & 22.2 \\
\hline Others & 4.0 & 1.8 & 3.1 & 18.4 & 19.3 & 18.7 & 11.3 & 9.4 & 10.6 \\
\hline
\end{tabular}

Notes: Sample size: 12,348 person-y ears (2,058 persons) for females and 10,728 person-years (1,788 persons) for males. ${ }^{(a)}$ Conditional on providing respective unpaid care. Longitudinal sampling weights are used. 
Table 2: Caregiving trajectories by gender

\begin{tabular}{|c|c|c|c|c|c|c|}
\hline \multirow{3}{*}{$\begin{array}{l}\text { Wave } \mathrm{t} \\
\text { Panel A: Resident/Non-resident care }\end{array}$} & \multicolumn{6}{|c|}{ Wave $\mathbf{t + 1}$} \\
\hline & \multicolumn{3}{|c|}{ Female } & \multicolumn{3}{|c|}{ Male } \\
\hline & $\begin{array}{c}\text { Non } \\
\text { caregiver }\end{array}$ & Residential & $\begin{array}{c}\text { Non- } \\
\text { residential }\end{array}$ & $\begin{array}{c}\text { Non } \\
\text { caregiver }\end{array}$ & Residential & $\begin{array}{c}\text { Non- } \\
\text { residential }\end{array}$ \\
\hline Non caregiver & 95.5 & 1.7 & 2.8 & 96.7 & 1.4 & 2.0 \\
\hline Residential & 32.3 & 65.4 & 2.3 & 38.5 & 59.8 & 1.7 \\
\hline Non-residential & 50.2 & 2.0 & 47.8 & 65.0 & 1.9 & 33.1 \\
\hline Total & 90.1 & 4.7 & 5.2 & 93.7 & 3.5 & 2.8 \\
\hline Panel B: Main/Secondary care & $\begin{array}{c}\text { Non } \\
\text { caregiver }\end{array}$ & Main & Secondary & $\begin{array}{c}\text { Non } \\
\text { caregiver }\end{array}$ & Main & Secondary \\
\hline Non caregiver & 95.5 & 2.3 & 2.2 & 96.7 & 1.2 & 2.2 \\
\hline Main & 35.2 & 54.5 & 10.3 & 39.3 & 50.8 & 9.9 \\
\hline Secondary & 50.8 & 11.7 & 37.5 & 58.1 & 5.2 & 36.7 \\
\hline Total & 90.1 & 5.7 & 4.1 & 93.7 & 2.7 & 3.6 \\
\hline
\end{tabular}

Notes: Sample size: 12,348 person-years (2,058 persons) for females and 10,728 person-y ears (1,788 persons) for males. Longitudinal sampling weights are used. Percentage of those in current wave state moving to the next wave state (row percentage) is reported (\%). 
Table 3a: Caregiving dynamics: Resident versus non-resident care - Model 1 with employment status (main results)

\begin{tabular}{|c|c|c|c|c|c|c|c|c|}
\hline \multirow[b]{3}{*}{ Variables } & \multicolumn{4}{|c|}{ Female } & \multicolumn{4}{|c|}{ Male } \\
\hline & \multicolumn{2}{|c|}{ Specification I } & \multicolumn{2}{|c|}{ Specification II } & \multicolumn{2}{|c|}{ Specification I } & \multicolumn{2}{|c|}{ Specification II } \\
\hline & $\begin{array}{c}\text { Resident } \\
\text { care }\end{array}$ & $\begin{array}{c}\text { Non-resident } \\
\text { care }\end{array}$ & $\begin{array}{l}\text { Resident } \\
\text { care }\end{array}$ & $\begin{array}{c}\text { Non-resident } \\
\text { care }\end{array}$ & $\begin{array}{l}\text { Resident } \\
\text { care }\end{array}$ & $\begin{array}{c}\text { Non-resident } \\
\text { care }\end{array}$ & $\begin{array}{l}\text { Resident } \\
\text { care }\end{array}$ & $\begin{array}{c}\text { Non-resident } \\
\text { care }\end{array}$ \\
\hline Resident care last year ${ }^{(a)}$ & $4.99 * * *$ & 2.01 & $4.91 * * *$ & 1.37 & $3.03 * * *$ & -0.40 & $3.08 * * *$ & 0.05 \\
\hline Non-resident care last year ${ }^{\text {(a) }}$ & 0.71 & $5.39 * * *$ & 0.46 & $5.39 * * *$ & 0.76 & $3.94 * * *$ & 1.26 & $3.21 * * *$ \\
\hline Resident care at $\mathrm{t}=1^{\text {(a) }}$ & $23.59 * * *$ & 0.46 & $23.77 * * *$ & 1.13 & $27.56 * * *$ & $4.17^{* *}$ & $27.53 * * *$ & $3.91 * *$ \\
\hline Non-resident care at $t=1$ (a) & 1.45 & $15.79 * * *$ & $1.71^{*}$ & $15.87 * * *$ & $4.78 * * *$ & $10.39 * * *$ & $4.54 * * *$ & $10.62 * * *$ \\
\hline Work full time last year ${ }^{(b)}$ & $-1.98 * * *$ & $-1.54^{* *}$ & $-2.00 * * *$ & $-1.57 * *$ & $-1.50 * *$ & -0.05 & $-1.51^{* *}$ & -0.04 \\
\hline Work part time last year ${ }^{(\mathrm{b})}$ & -0.36 & -0.57 & -0.36 & -0.59 & $-1.38 * *$ & $1.70^{*}$ & $-1.38 * *$ & $1.52 *$ \\
\hline Self-employed last year ${ }^{(b)}$ & -0.15 & -1.04 & -0.18 & -1.03 & $-1.58 * *$ & 0.56 & $-1.60 * *$ & 0.57 \\
\hline Work full time at $t=1^{\text {(b) }}$ & -0.80 & 0.84 & -0.77 & 0.81 & -0.36 & -0.40 & -0.32 & -0.30 \\
\hline Work part time at $\mathrm{t}=1^{\text {(b) }}$ & $-1.04 *$ & 0.61 & $-1.00 *$ & 0.54 & -1.48 & $-2.21 * *$ & -1.44 & $-2.09 * *$ \\
\hline Self-employed at $t=1^{\text {(b) }}$ & -1.05 & -1.06 & -1.00 & -1.14 & -0.64 & $-1.45^{*}$ & -0.55 & -1.35 \\
\hline Unobserved heterogeneity (SD) & $\begin{array}{l}2.45^{* * *} \\
(0.21)\end{array}$ & $\begin{array}{l}1.73^{* * *} \\
(0.14)\end{array}$ & $\begin{array}{l}2.48 * * * \\
(0.21)\end{array}$ & $\begin{array}{l}1.70 * * * \\
(0.14)\end{array}$ & $\begin{array}{l}2.39 * * * \\
(0.29)\end{array}$ & $\begin{array}{l}1.55^{* * * *} \\
(0.18)\end{array}$ & $\begin{array}{l}2.38 * * * \\
(0.29)\end{array}$ & $\begin{array}{l}1.56 * * * \\
(0.18)\end{array}$ \\
\hline Error correlation & \multicolumn{6}{|c|}{0.28} & \multicolumn{2}{|c|}{$-0.52 * * *$} \\
\hline Observations & \multicolumn{2}{|c|}{12348} & \multicolumn{2}{|c|}{12348} & \multicolumn{2}{|c|}{10728} & \multicolumn{2}{|c|}{10728} \\
\hline No of persons & \multirow{2}{*}{\multicolumn{2}{|c|}{$\begin{array}{c}2058 \\
-2846.82\end{array}$}} & \multicolumn{2}{|c|}{2058} & \multicolumn{2}{|c|}{1788} & \multicolumn{2}{|c|}{1788} \\
\hline Log-likelihood & & & \multicolumn{2}{|c|}{-2845.98} & \multicolumn{2}{|c|}{-1755.82} & \multicolumn{2}{|c|}{-1751.53} \\
\hline Pseudo R2 & \multicolumn{2}{|c|}{0.05} & \multicolumn{2}{|c|}{0.05} & \multicolumn{2}{|c|}{0.03} & \multicolumn{2}{|c|}{0.03} \\
\hline AIC & \multicolumn{2}{|c|}{5969.64} & \multicolumn{2}{|c|}{5969.96} & \multicolumn{2}{|c|}{3787.63} & \multicolumn{2}{|c|}{3781.06} \\
\hline BIC & \multicolumn{2}{|c|}{6993.78} & \multicolumn{2}{|c|}{7001.52} & \multirow{2}{*}{\multicolumn{2}{|c|}{4792.36}} & & .07 \\
\hline P LR & & & & & & & & \\
\hline
\end{tabular}

Notes: Average marginal effects (AMEs), expressed in percentage points, are reported. AME is calculated at mean for continuous variables; for dummy variables: the AME is for discrete change from 0 to $1 .{ }^{\text {(a) }}$ Non-carer is the base group; ${ }^{(b)}$ Unemployed is the base group. Standard errors are in parentheses. $* * * p<0.01$, $* * p<0.05, * p<0.1$. The statistical significance level for AMEs corresponds to that of coefficient estimates. Specification I (II) does not (does) allow for correlation between errors in two care outcome equations. P (LR) is P value from an LR test for the significance of the error correlation. Coefficient estimates of main and other variables are rep orted in Appendix Table A6. 
Table 3b: Caregiving intensity dynamics: Resident versus non-resident care - Model 2 with work security and flexibility indicators

\begin{tabular}{|c|c|c|c|c|c|c|c|c|}
\hline \multirow[b]{3}{*}{ Variables } & \multicolumn{4}{|c|}{ Female } & \multicolumn{4}{|c|}{ Male } \\
\hline & \multicolumn{2}{|c|}{ Specification I } & \multicolumn{2}{|c|}{ Specification II } & \multicolumn{2}{|c|}{ Specification I } & \multicolumn{2}{|c|}{ Specification II } \\
\hline & $\begin{array}{l}\text { Resident } \\
\text { care }\end{array}$ & $\begin{array}{c}\text { Non- } \\
\text { resident } \\
\text { care } \\
\end{array}$ & $\begin{array}{l}\text { Resident } \\
\text { care }\end{array}$ & $\begin{array}{c}\text { Non- } \\
\text { resident } \\
\text { care } \\
\end{array}$ & $\begin{array}{c}\text { Resident } \\
\text { care }\end{array}$ & $\begin{array}{c}\text { Non- } \\
\text { resident } \\
\text { care } \\
\end{array}$ & $\begin{array}{l}\text { Resident } \\
\text { care }\end{array}$ & $\begin{array}{c}\text { Non- } \\
\text { resident } \\
\text { care } \\
\end{array}$ \\
\hline Resident care last year (a) & $5.58 * * *$ & 2.04 & $5.49 * * *$ & 1.61 & $2.84 * * *$ & -0.23 & $2.96 * * *$ & 0.26 \\
\hline Non-resident care last year ${ }^{(a)}$ & 0.71 & $5.15^{* * *}$ & 0.45 & $5.15 * * *$ & 0.32 & $4.07 * * *$ & 0.82 & $3.75^{* * *}$ \\
\hline Resident care at $\mathrm{t}=1^{\text {(a) }}$ & $23.95 * * *$ & -0.04 & $24.09 * * *$ & 0.33 & $30.42 * * *$ & $5.22 * * *$ & $29.96 * * *$ & $4.20 * *$ \\
\hline Non-resident care at $t=1^{\text {(a) }}$ & 0.57 & $16.17 * * *$ & 0.52 & $16.19 * * *$ & $5.86 * * *$ & $10.01 * * *$ & $5.65 * * *$ & $10.17 * * *$ \\
\hline Job security index last year & -0.09 & -0.04 & -0.09 & -0.03 & 0.17 & 0.06 & 0.17 & 0.06 \\
\hline Work and life job satisfaction last year & 0.15 & 0.00 & 0.14 & 0.00 & 0.01 & -0.03 & 0.02 & -0.03 \\
\hline Unemployed last year & 0.75 & 0.92 & 0.77 & 0.90 & 1.07 & -0.70 & 1.08 & -0.69 \\
\hline Job security index at $t=1$ & 0.16 & -0.09 & 0.16 & -0.08 & 0.00 & $-0.22 * *$ & 0.01 & $-0.23^{* *}$ \\
\hline Work and life job satisfaction at $\mathrm{t}=1$ & -0.08 & -0.03 & -0.07 & -0.03 & -0.05 & 0.02 & -0.06 & 0.02 \\
\hline Unemployed at $\mathrm{t}=1$ & 0.64 & -0.22 & 0.61 & -0.19 & 1.62 & 1.12 & 1.58 & 1.11 \\
\hline Unobserved heterogeneity (SD) & $\begin{array}{l}2.53 * * * \\
(0.28)\end{array}$ & $\begin{array}{l}1.74^{* * * *} \\
(0.14)\end{array}$ & $\begin{array}{l}2.55^{* * *} \\
(0.27)\end{array}$ & $\begin{array}{l}1.73^{* * *} \\
(0.14)\end{array}$ & $\begin{array}{l}2.43 * * * \\
(0.27)\end{array}$ & $\begin{array}{l}1.56^{* * *} \\
(0.19)\end{array}$ & $\begin{array}{l}2.40 * * * \\
(0.27)\end{array}$ & $\begin{array}{l}1.48^{* * * *} \\
(0.18)\end{array}$ \\
\hline Error correlation & \multicolumn{4}{|c|}{$\begin{array}{c}0.18 \\
(0.29)\end{array}$} & & & \multicolumn{2}{|c|}{$\begin{array}{c}-0.54^{* *} \\
(0.22)\end{array}$} \\
\hline Observations & \multicolumn{2}{|c|}{11988} & \multicolumn{2}{|c|}{11988} & \multicolumn{2}{|c|}{10326} & \multicolumn{2}{|c|}{10326} \\
\hline No of persons & \multicolumn{2}{|c|}{1998} & \multicolumn{2}{|c|}{1998} & \multicolumn{2}{|c|}{1721} & \multicolumn{2}{|c|}{1721} \\
\hline Log-likelihood & \multicolumn{2}{|c|}{-2744.62} & \multicolumn{2}{|c|}{-2744.44} & \multicolumn{2}{|c|}{-1631.07} & \multicolumn{2}{|c|}{-1629.20} \\
\hline Pseudo R2 & \multicolumn{2}{|c|}{0.04} & \multicolumn{2}{|c|}{0.04} & \multicolumn{2}{|c|}{0.04} & \multicolumn{2}{|c|}{0.04} \\
\hline AIC & \multicolumn{2}{|c|}{5765.25} & \multicolumn{2}{|c|}{5766.87} & \multicolumn{2}{|c|}{3538.13} & \multicolumn{2}{|c|}{3536.40} \\
\hline BIC & \multirow{2}{*}{\multicolumn{2}{|c|}{6785.30}} & \multirow{2}{*}{\multicolumn{2}{|c|}{$\begin{array}{c}6794.31 \\
0.83\end{array}$}} & \multirow{2}{*}{\multicolumn{2}{|c|}{4537.59}} & \multirow{2}{*}{\multicolumn{2}{|c|}{$\begin{array}{c}4543.10 \\
0.15\end{array}$}} \\
\hline P LR & & & & & & & & \\
\hline
\end{tabular}

Notes: Average marginal effects (AMEs), expressed in percentage points, are reported. AME is calculated at mean for continuous variables; for dummy variables: the AME is for discrete change from 0 to 1 . (a) Non-carer is the base group; Standard errors are in parentheses. ${ }^{* * *} \mathrm{p}<0.01, * * \mathrm{p}<0.05$, ${ }^{*} \mathrm{p}<0.1$. The statistical significance level for AMEs corresponds to that of coefficient estimates (reported in Appendix Table A7). Specification I (II) does not (does) allow for correlation between errors in two care outcome equations. P (LR) is P value from an LR test for the significance of the error correlation. 
Table 3c: Caregiving intensity dynamics: Resident versus non-resident care - Model 3 with overall work satisfaction indicator

\begin{tabular}{|c|c|c|c|c|c|c|c|c|}
\hline \multirow[b]{3}{*}{ Variables } & \multicolumn{4}{|c|}{ Female } & \multicolumn{4}{|c|}{ Male } \\
\hline & \multicolumn{2}{|c|}{ Specification I } & \multicolumn{2}{|c|}{ Specification II } & \multicolumn{2}{|c|}{ Specification I } & \multicolumn{2}{|c|}{ Specification II } \\
\hline & $\begin{array}{l}\text { Resident } \\
\text { care }\end{array}$ & $\begin{array}{l}\text { Non- } \\
\text { resident } \\
\text { care }\end{array}$ & $\begin{array}{c}\text { Resident } \\
\text { care }\end{array}$ & $\begin{array}{l}\text { Non- } \\
\text { resident } \\
\text { care }\end{array}$ & $\begin{array}{c}\text { Resident } \\
\text { care }\end{array}$ & $\begin{array}{l}\text { Non- } \\
\text { resident } \\
\text { care }\end{array}$ & $\begin{array}{l}\text { Resident } \\
\text { care }\end{array}$ & $\begin{array}{c}\text { Non- } \\
\text { resident } \\
\text { care }\end{array}$ \\
\hline Resident care last year ${ }^{(a)}$ & $5.71^{* * *}$ & 2.04 & $5.61^{* * *}$ & 1.62 & $2.88 * * *$ & -0.22 & $3.02 * * *$ & 0.22 \\
\hline Non-resident care last year ${ }^{(a)}$ & 0.70 & $5.12 * * *$ & 0.49 & $5.12^{* * *}$ & 0.29 & $4.1^{* * *}$ & 0.79 & $3.76^{* * *}$ \\
\hline Resident care at $\mathrm{t}=1^{\text {(a) }}$ & $23.6^{* * *}$ & -0.05 & $23.74 * * *$ & 0.33 & $30.08 * * *$ & $5.25 * * *$ & $29.59 * * *$ & $4.25^{* *}$ \\
\hline Non-resident care at $t=1$ (a) & 0.38 & $16.32 * * *$ & 0.47 & $16.22 * * *$ & $5.68 * * *$ & $9.80 * * *$ & $5.50 * * *$ & $9.98 * * *$ \\
\hline Overall work satisfaction last year & -0.14 & 0.03 & -0.14 & 0.03 & -0.03 & 0.03 & -0.03 & 0.04 \\
\hline Unemployed last year & 0.73 & 0.89 & 0.74 & 0.87 & $1.18^{*}$ & -0.61 & $1.18^{*}$ & -0.60 \\
\hline Overall work satisfaction at $\mathrm{t}=1$ & 0.08 & -0.11 & 0.09 & -0.10 & -0.05 & -0.09 & -0.04 & -0.09 \\
\hline Unemployed at $\mathrm{t}=1$ & 0.66 & -0.20 & 0.63 & -0.18 & 1.41 & 0.85 & 1.39 & 0.84 \\
\hline Unobserved heterogeneity (SD) & $\begin{array}{l}2.49 * * * \\
(0.25)\end{array}$ & $\begin{array}{l}1.75^{* * *} \\
(0.14)\end{array}$ & $\begin{array}{l}2.52 * * * \\
(0.26)\end{array}$ & $\begin{array}{l}1.74 * * * \\
(0.14)\end{array}$ & $\begin{array}{l}2.39 * * * \\
(0.27)\end{array}$ & $\begin{array}{l}1.57^{* * *} \\
(0.19)\end{array}$ & $\begin{array}{l}2.37 * * * \\
(0.27)\end{array}$ & $\begin{array}{l}1.50 * * * \\
(0.18)\end{array}$ \\
\hline Error correlation & \multicolumn{4}{|c|}{$\begin{array}{c}0.17 \\
(0.26)\end{array}$} & & & \multicolumn{2}{|c|}{$\begin{array}{c}-0.52 * * \\
(0.22)\end{array}$} \\
\hline Observations & \multicolumn{2}{|c|}{11988} & \multicolumn{2}{|c|}{11988} & \multicolumn{2}{|c|}{10326} & \multicolumn{2}{|c|}{10326} \\
\hline No of persons & \multicolumn{2}{|c|}{1998} & \multicolumn{2}{|c|}{1998} & \multicolumn{2}{|c|}{1721} & \multicolumn{2}{|c|}{1721} \\
\hline Log-likelihood & \multicolumn{2}{|c|}{-2745.90} & \multicolumn{2}{|c|}{-2745.69} & \multicolumn{2}{|c|}{-1634.63} & \multicolumn{2}{|c|}{-1632.86} \\
\hline Pseudo R2 & \multicolumn{2}{|c|}{0.04} & \multicolumn{2}{|c|}{0.04} & \multicolumn{2}{|c|}{0.03} & \multicolumn{2}{|c|}{0.04} \\
\hline AIC & \multicolumn{2}{|c|}{5759.79} & \multicolumn{2}{|c|}{5761.38} & \multicolumn{2}{|c|}{3537.26} & \multicolumn{2}{|c|}{3535.72} \\
\hline BIC & \multirow{2}{*}{\multicolumn{2}{|c|}{6750.27}} & \multicolumn{2}{|c|}{6759.26} & \multicolumn{2}{|c|}{4507.75} & \multicolumn{2}{|c|}{4513.45} \\
\hline P LR & & & \multicolumn{2}{|c|}{0.82} & & & & \\
\hline
\end{tabular}

Notes: Average marginal effects (AMEs), expressed in percentage points, are reported. AME is calculated at mean for continuous variables; for dummy variables: the AME is for discrete change from 0 to $1 .{ }^{\text {(a) }}$ Non-carer is the base group; Standard errors are in parentheses. ${ }^{* * *} \mathrm{p}<0.01, * * \mathrm{p}<0.05$, ${ }^{*} \mathrm{p}<0.1$. The statistical significance level for AMEs corresponds to that of coefficient estimates (reported in Appendix Table A8). Specification I (II) does not (does) allow for correlation between errors in two care outcome equations. P (LR) is P value from an LR test for the significance of the error correlation. 
Table 4a: Caregiving intensity dynamics: Main versus secondary care - Model 1 with employment status (main results)

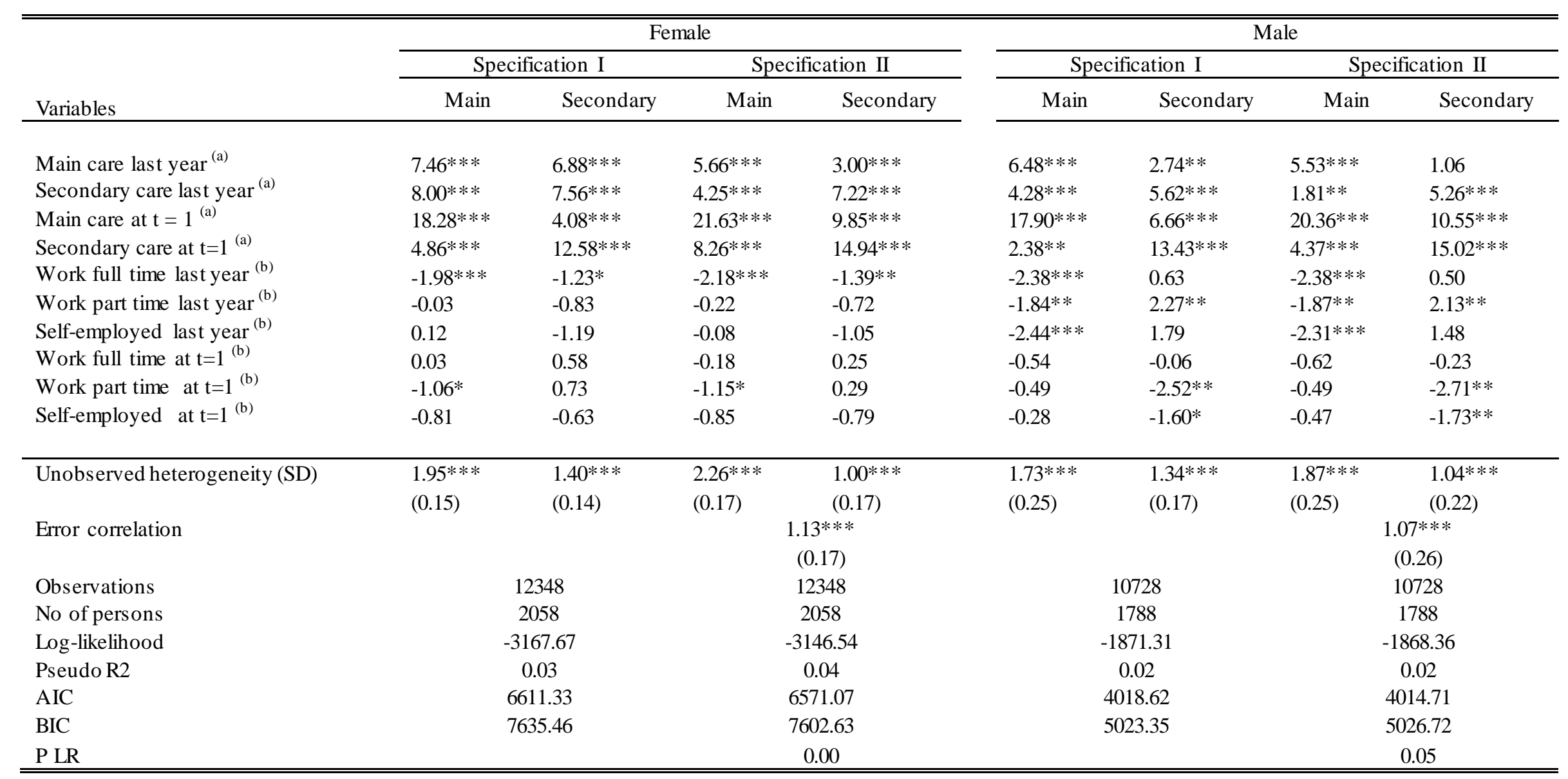

Notes: Average marginal effects (AMEs), expressed in percentage points, are reported. AME is calculated at mean for continuous variables; for dummy variables: the AME is for discrete change from 0 to $1 .{ }^{\text {(a) }}$ Non-carer is the base group; ${ }^{(b)}$ Unemployed is the base group. Standard errors are in parentheses. ${ }^{* * *} \mathrm{p}<0.01,{ }^{* *} \mathrm{p}<0.05$, ${ }^{*} \mathrm{p}<0.1$. The statistical significance level for AMEs corresponds to that of coefficient estimates. Specification I (II) does not (does) allow for correlation between errors in two care outcome equations. P (LR) is P value from an LR test for the significance of the error correlation. Coefficient estimates of main and other variables are reported in Appendix Table A9. 
Table 4b: Caregiving intensity dynamics: Main versus secondary care - Model 2 with work security and flexibility indicators

\begin{tabular}{|c|c|c|c|c|c|c|c|c|}
\hline \multirow[b]{3}{*}{ Variables } & \multicolumn{4}{|c|}{ Female } & \multicolumn{4}{|c|}{ Male } \\
\hline & \multicolumn{2}{|c|}{ Specification I } & \multicolumn{2}{|c|}{ Specification II } & \multicolumn{2}{|c|}{ Specification I } & \multicolumn{2}{|c|}{ Specification II } \\
\hline & Main & Secondary & Main & Secondary & Main & Secondary & Main & Secondary \\
\hline Main care last year ${ }^{(a)}$ & $7.66^{* * *}$ & $6.37 * * *$ & $5.61^{* * *}$ & $2.72 * * *$ & $6.57 * * *$ & $3.34 * * *$ & $5.07 * * *$ & 1.12 \\
\hline Secondary care last year (a) & $7.22 * * *$ & $7.14^{* * *}$ & $4.18^{* * *}$ & $6.13 * * *$ & $4.38 * * *$ & $5.93 * * *$ & $1.92 * *$ & $5.12 * * *$ \\
\hline Main care at $t=1^{(a)}$ & $17.93 * * *$ & $4.56 * * *$ & $22.19 * * *$ & $9.67 * * *$ & $19.38 * * *$ & $6.38 * * *$ & $22.33 * * *$ & $11.88 * * *$ \\
\hline Secondary care at $\mathrm{t}=1^{\text {(a) }}$ & $4.76^{* * *}$ & $13.06 * * *$ & $8.89 * * *$ & $15.97 * * *$ & $2.43^{* *}$ & $14.85 * * *$ & $4.79 * * *$ & $17.19 * * *$ \\
\hline Job security index last year & $-0.25 * *$ & 0.09 & $-0.26 * *$ & 0.09 & 0.17 & 0.10 & 0.19 & 0.12 \\
\hline Work and life job satisfaction last year & 0.15 & -0.04 & 0.19 & -0.03 & -0.03 & 0.03 & -0.03 & 0.03 \\
\hline Unemployed last year & 0.82 & 0.93 & $0.94 *$ & $1.02^{*}$ & $2.48 * * *$ & $-1.45 * *$ & $2.24 * * *$ & $-1.43 * *$ \\
\hline Job security index at $\mathrm{t}=1$ & 0.11 & -0.10 & 0.11 & -0.09 & $-0.23 *$ & $-0.21^{*}$ & $-0.22 *$ & $-0.21 *$ \\
\hline Work and life job satisfaction at $\mathrm{t}=1$ & -0.17 & -0.02 & -0.03 & -0.01 & 0.06 & -0.05 & 0.09 & -0.05 \\
\hline Unemployed at $\mathrm{t}=1$ & 0.52 & -0.49 & 0.51 & -0.49 & 1.20 & 1.13 & 1.50 & 1.60 \\
\hline Unobserved heterogeneity (SD) & $\begin{array}{l}1.88^{* * * *} \\
(0.16)\end{array}$ & $\begin{array}{l}1.43^{* * *} \\
(0.14)\end{array}$ & $\begin{array}{l}2.35^{* * *} \\
(0.19)\end{array}$ & $\begin{array}{l}1.17 * * * \\
(0.15)\end{array}$ & $\begin{array}{l}1.63^{* * * *} \\
(0.22)\end{array}$ & $\begin{array}{l}1.39 * * * \\
(0.18)\end{array}$ & $\begin{array}{l}1.92 * * * \\
(0.25)\end{array}$ & $\begin{array}{l}1.20 * * * \\
(0.21)\end{array}$ \\
\hline Error correlation & \multicolumn{4}{|c|}{$\begin{array}{c}1.13 * * * \\
(0.17)\end{array}$} & & & \multicolumn{2}{|c|}{$\begin{array}{c}1.06^{* * *} \\
(0.21)\end{array}$} \\
\hline Observations & \multicolumn{2}{|c|}{11988} & \multicolumn{2}{|c|}{11988} & \multicolumn{2}{|c|}{10326} & \multicolumn{2}{|c|}{10326} \\
\hline No of persons & \multicolumn{2}{|c|}{1998} & \multicolumn{2}{|c|}{1998} & \multicolumn{2}{|c|}{1721} & \multicolumn{2}{|c|}{1721} \\
\hline Log-likelihood & \multicolumn{2}{|c|}{-3033.96} & \multicolumn{2}{|c|}{-3010.96} & \multicolumn{2}{|c|}{-1755.27} & \multicolumn{2}{|c|}{-1747.50} \\
\hline Pseudo R2 & \multicolumn{2}{|c|}{0.03} & \multicolumn{2}{|c|}{0.04} & \multicolumn{2}{|c|}{0.02} & \multicolumn{2}{|c|}{0.02} \\
\hline AIC & \multicolumn{2}{|c|}{6343.91} & \multicolumn{2}{|c|}{6299.92} & \multicolumn{2}{|c|}{3786.54} & \multicolumn{2}{|c|}{3772.99} \\
\hline $\mathrm{BIC}$ & \multicolumn{2}{|c|}{7363.96} & \multicolumn{2}{|c|}{7327.36} & \multicolumn{2}{|c|}{4785.99} & \multicolumn{2}{|c|}{4779.69} \\
\hline P LR & & & \multicolumn{2}{|c|}{0.00} & & & & 00 \\
\hline
\end{tabular}

change from 0 to 1 . (a) Non-carer is the base group; Standard errors are in parentheses. ${ }^{* * *} \mathrm{p}<0.01, * * \mathrm{p}<0.05$, $*$ p $<0.1$. The statistical significance level for AMEs corresponds to that of coefficient estimates (reported in Appendix Table A10). Specification I (II) does not (does) allow for correlation between errors in two care outcome equations. P (LR) is P value from an LR test for the significance of the error correlation. 
Table 4c: Caregiving intensity dynamics: Main versus secondary care - Model 3 with overall work satisfaction indicator

\begin{tabular}{|c|c|c|c|c|c|c|c|c|}
\hline \multirow[b]{3}{*}{ Variables } & \multicolumn{4}{|c|}{ Female } & \multicolumn{4}{|c|}{ Male } \\
\hline & \multicolumn{2}{|c|}{ Specification I } & \multicolumn{2}{|c|}{ Specification II } & \multicolumn{2}{|c|}{ Specification I } & \multicolumn{2}{|c|}{ Specification II } \\
\hline & Main & Secondary & Main & Secondary & Main & Secondary & Main & Secondary \\
\hline Main care last year ${ }^{(a)}$ & $7.86 * * *$ & $6.48 * * *$ & $5.87 * * *$ & $2.82 * * *$ & $6.22 * * *$ & $3.38 * * *$ & $4.9 * * *$ & 1.15 \\
\hline $\begin{array}{l}\text { Secondary care last year } \\
\text { Main care at } t=1^{\text {(a) }}\end{array}$ & $\begin{array}{l}7.39 * * * \\
17.65 * * *\end{array}$ & $\begin{array}{l}7.27 * * * \\
4.54 * * *\end{array}$ & $\begin{array}{l}4.29 * * * \\
21.81 * * *\end{array}$ & $\begin{array}{l}6.17 * * * \\
9.54 * * *\end{array}$ & $\begin{array}{l}4.31 * * * \\
19.75^{* * *}\end{array}$ & $\begin{array}{l}6.01 * * * \\
6.38 * * *\end{array}$ & $\begin{array}{l}1.89 * * \\
22.42 * * *\end{array}$ & $\begin{array}{l}5.16^{* * *} \\
11.98^{* * * *}\end{array}$ \\
\hline $\begin{array}{l}\text { Secondary care at } \mathrm{t}=1^{(\mathrm{a})} \\
\text { Overall work satisfaction last year }\end{array}$ & $\begin{array}{l}4.57 * * * \\
-0.06\end{array}$ & $\begin{array}{l}12.89 * * * \\
-0.09\end{array}$ & $\begin{array}{l}8.88 * * * \\
-0.02\end{array}$ & $\begin{array}{l}15.83^{* * *} \\
-0.08\end{array}$ & $\begin{array}{l}2.45^{* *} \\
0.13\end{array}$ & $\begin{array}{l}14.78^{* * *} \\
-0.06\end{array}$ & $\begin{array}{l}4.8^{* * *} \\
0.13\end{array}$ & $\begin{array}{l}17.26^{* * * *} \\
-0.04\end{array}$ \\
\hline $\begin{array}{l}\text { Unemployed last year } \\
\text { Overall work satisfaction at } \mathrm{t}=1\end{array}$ & $\begin{array}{l}0.67 \\
-0.16\end{array}$ & $\begin{array}{l}1.01^{*} \\
0.1\end{array}$ & $\begin{array}{l}0.74 \\
-0.18\end{array}$ & $\begin{array}{l}1.09 * \\
0.05\end{array}$ & $\begin{array}{l}2.66 * * * \\
-0.34 * *\end{array}$ & $\begin{array}{l}-1.42 * * \\
0.09\end{array}$ & $\begin{array}{l}2.44 * * * \\
-0.32 * *\end{array}$ & $\begin{array}{l}-1.4^{*} \\
0.07\end{array}$ \\
\hline Unemployed at $\mathrm{t}=1$ & 0.66 & -0.56 & 0.68 & -0.55 & 1.02 & 0.87 & 1.27 & 1.28 \\
\hline Unobserved heterogeneity (SD) & $\begin{array}{l}1.85 * * * \\
(0.15)\end{array}$ & $\begin{array}{l}1.41^{* * *} \\
(0.14)\end{array}$ & $\begin{array}{l}2.28 * * * \\
(0.18)\end{array}$ & $\begin{array}{l}1.18 * * * \\
(0.15)\end{array}$ & $\begin{array}{l}1.68 * * * \\
(0.23)\end{array}$ & $\begin{array}{l}1.39 * * * \\
(0.18)\end{array}$ & $\begin{array}{l}1.95 * * * \\
(0.27)\end{array}$ & $\begin{array}{l}1.21^{* * *} \\
(0.21)\end{array}$ \\
\hline Error correlation & \multicolumn{4}{|c|}{$\begin{array}{c}1.12^{* * *} \\
(0.18)\end{array}$} & & & \multicolumn{2}{|c|}{$\begin{array}{c}1.08 * * * \\
(0.23)\end{array}$} \\
\hline Observations & \multicolumn{2}{|c|}{11988} & \multicolumn{2}{|c|}{11988} & \multicolumn{2}{|c|}{10326} & \multicolumn{2}{|c|}{10326} \\
\hline No of persons & \multicolumn{2}{|c|}{1998} & \multicolumn{2}{|c|}{1998} & \multicolumn{2}{|c|}{1721} & \multicolumn{2}{|c|}{1721} \\
\hline Log-likelihood & \multicolumn{2}{|c|}{-3037.02} & \multicolumn{2}{|c|}{-3014.45} & \multicolumn{2}{|c|}{-1756.15} & \multicolumn{2}{|c|}{-1748.34} \\
\hline Pseudo R2 & \multicolumn{2}{|c|}{0.03} & \multicolumn{2}{|c|}{0.04} & \multicolumn{2}{|c|}{0.02} & \multicolumn{2}{|c|}{0.03} \\
\hline AIC & \multicolumn{2}{|c|}{6342.05} & \multicolumn{2}{|c|}{6298.89} & \multicolumn{2}{|c|}{3780.29} & \multicolumn{2}{|c|}{3766.68} \\
\hline $\begin{array}{l}\text { BIC } \\
\text { P LR }\end{array}$ & \multicolumn{2}{|c|}{7332.53} & \multicolumn{2}{|c|}{$\begin{array}{c}7296.77 \\
0.00\end{array}$} & \multicolumn{2}{|c|}{4750.78} & \multicolumn{2}{|c|}{$\begin{array}{c}4744.40 \\
0.00\end{array}$} \\
\hline
\end{tabular}

Notes: Average marginal effects (AMEs), expressed in percentage points, are reported. AME is calculated at mean for continuous variables; for dummy variables: the AME is for discrete

change from 0 to 1 . ${ }^{\text {(a) }}$ Non-carer is the base group; Standard errors are in parentheses. ${ }^{* * *} \mathrm{p}<0.01, * * \mathrm{p}<0.05$, ${ }^{*} \mathrm{p}<0.1$. The statistical significance level for AMEs corresponds to that of coefficient estimates. Specification I (II) does not (does) allow for correlation between errors in two care outcome equations. P (LR) is P value from an LR test for the significance of the error correlation. Coefficient estimates of main variables are reported in Appendix Table A11. 
Appendix Tables for refereeing purposes or online publication 
Appendix Table A1: Variable description and summary statistics

\begin{tabular}{|c|c|c|c|c|}
\hline $\begin{array}{l}\text { Variable } \\
\end{array}$ & Description & Female & Male & Total \\
\hline Caregiving status & As defined in the text & & & \\
\hline Labour market status & As defined in the text & & & \\
\hline Job security perception & $\begin{array}{l}\text { A number between } 0 \text { and } 10 \text { to indicate how sat isfied an individual is with the job security aspect of the job. A higher value indicates more } \\
\text { satisfaction. }\end{array}$ & 8.05 & 7.94 & 7.99 \\
\hline Work life flexibility perception & $\begin{array}{l}\text { A number between } 0 \text { and } 10 \text { to indicate how satisfied an individual is with the job security aspect of the job. A higher value indicates more } \\
\text { satisfaction. }\end{array}$ & 7.55 & 7.44 & 7.49 \\
\hline Overall job satisfaction & $\begin{array}{l}\text { A number between } 0 \text { and } 10 \text { to indicate how satisfied an individual is with the overall job satisfaction aspect of the job. A higher value indicates } \\
\text { more satisfaction. }\end{array}$ & 7.79 & 7.61 & 7.69 \\
\hline Age & Age last birthday at June 30 (year) & 45.77 & 45.98 & 45.87 \\
\hline Immigrant from an ESB country & $\begin{array}{l}\text { Dummy variable: }=1 \text { if country of birth is an English Speaking Background (ESB) country, = } 0 \text { if otherwise. ESB countries include UK, } \\
\text { Ireland, Canada, New Zealand, South Africa and USA. }\end{array}$ & 0.10 & 0.12 & 0.11 \\
\hline $\begin{array}{l}\text { Immigrant from a northwest Europe } \\
\text { NESB country }\end{array}$ & $\begin{array}{l}\text { Dummy variable: = } 1 \text { if country of birth is a Non-English Speaking Background (NESB) country from the northern/western Europe, = } 0 \text { if } \\
\text { otherwise. NESB countries from northern/western Europe include Austria, Belgium, France, Germany, Liechtenstein, Luxembourg, Monaco, } \\
\text { the Netherlands, and Switzerland. }\end{array}$ & 0.02 & 0.01 & 0.02 \\
\hline Immigrant from a NESB country (other) & $\begin{array}{l}\text { Dummy variable: }=1 \text { if country of birth is a Non-English Speaking Background (NESB) country outside the northem/west em Europe, }=0 \text { if } \\
\text { otherwise. }\end{array}$ & 0.11 & 0.11 & 0.11 \\
\hline Child immigrant & Dummy variable: $=1$ if migrated to Australia before age $19,=0$ if otherwise. & 0.45 & 0.44 & 0.45 \\
\hline Year 12 & Dummy variable: $=1$ if the highest education level achieved is Year 12, $=0$ if otherwise. & 0.14 & 0.12 & 0.13 \\
\hline Vocational training & Dummy variable: $=1$ if the highest education level achieved is vocational training, $=0$ if otherwise. & 0.35 & 0.48 & 0.41 \\
\hline Bachelor or higher & Dummy variable: $=1$ if the highest educat ion level achieved is bachelor or higher, = 0 if otherwise. & 0.20 & 0.19 & 0.20 \\
\hline Married/de facto & Dummy variable: $=1$ if current marital status is married or de facto $=0$ if otherwise. & 0.77 & 0.77 & 0.77 \\
\hline Separated/divorced/widowed & Dummy variable: $=1$ if current marital status is separated/divorced/widowed, $=0$ if otherwise. & 0.13 & 0.08 & 0.11 \\
\hline Disable & Dummy variable: $=1$ if has any long term health condition, disability or impairment, = 0 if otherwise. & 0.21 & 0.20 & 0.20 \\
\hline Non-wage household income & Normalized non-wage household income $(\$ 100,000)$ & 0.27 & 0.11 & 0.19 \\
\hline Home owner without mortgage & Dummy variable: $=1$ if is currently paying off mortgage, $=0$ if otherwise. & 0.45 & 0.48 & 0.47 \\
\hline Home owner with mortgage & Dummy variable: $=1$ if is currently owning home without mortgage, $=0$ if otherwise. & 0.33 & 0.3 & 0.31 \\
\hline Number of persons aged $0-4$ & Number of people in thehousehold in 0-4 age cohorts, excluding self (person) & 0.20 & 0.21 & 0.21 \\
\hline Number of persons aged 5-9 & Number of people in thehousehold in 5-9 age cohorts, excluding self (person) & 0.23 & 0.22 & 0.23 \\
\hline Number of persons aged $10-14$ & Number of people in the household in 10-14 age cohorts, excluding self (person) & 0.27 & 0.25 & 0.26 \\
\hline Number of persons aged $15-23$ & Number of people in thehousehold in $15-23$ age cohorts, excluding self (person) & 0.37 & 0.33 & 0.35 \\
\hline Number of persons aged $24-64$ & Number of people in thehousehold in 24-64 age cohorts, excluding self (person) & 0.83 & 0.87 & 0.85 \\
\hline Number of elderly & Number of people in thehousehold in 65+ age cohorts, excluding self (person) & 0.07 & 0.05 & 0.06 \\
\hline Death of close relative & Dummy variable: $=1$ if had a death of spouses, children or relatives last year, $=0$ if otherwise. & 0.12 & 0.11 & 0.11 \\
\hline Death of close friend & Dummy variable: $=1$ if had a death of close friend last year, $=0$ if otherwise. & 0.08 & 0.09 & 0.09 \\
\hline Injury to self & Dummy variable: $=1$ if had any serious personal injury/illness last year, $=0$ if otherwise. & 0.07 & 0.08 & 0.07 \\
\hline Injury/illness of relative/family member & Dummy variable: $=1$ if had any serious personal injury/illness of a relative or family member last year, $=0$ if otherwise. & 0.18 & 0.14 & 0.16 \\
\hline
\end{tabular}

Notes: Sample size: 12,348 person-years (2,058 persons) for females and 10,728 person-years (1,788 persons) for males. 
Appendix Table A2: Characteristics of carers and non-carers: by gender and caregiving status

\begin{tabular}{|c|c|c|c|c|c|c|c|c|c|c|c|c|}
\hline \multirow[b]{2}{*}{ Variables } & \multicolumn{6}{|c|}{ Female } & \multicolumn{6}{|c|}{ Male } \\
\hline & $\begin{array}{c}\text { Non } \\
\text { caregiver }\end{array}$ & $\begin{array}{c}\text { Main } \\
\text { resident }\end{array}$ & $\begin{array}{l}\text { Secondary } \\
\text { resident }\end{array}$ & $\begin{array}{l}\text { Main non- } \\
\text { resident }\end{array}$ & $\begin{array}{c}\text { Secondary } \\
\text { non- } \\
\text { resident } \\
\end{array}$ & Total & $\begin{array}{c}\text { Non } \\
\text { caregiver }\end{array}$ & $\begin{array}{c}\text { Main } \\
\text { resident }\end{array}$ & $\begin{array}{l}\text { Secondar } \\
\text { y resident }\end{array}$ & $\begin{array}{c}\text { Main } \\
\text { non- } \\
\text { resident }\end{array}$ & $\begin{array}{l}\text { Secondary } \\
\text { non- } \\
\text { resident } \\
\end{array}$ & Total \\
\hline Unemployed last year & 0.25 & 0.47 & 0.39 & 0.37 & 0.32 & 0.27 & 0.12 & 0.45 & 0.09 & 0.28 & 0.13 & 0.12 \\
\hline Worked full-timelast year & 0.37 & 0.15 & 0.25 & 0.27 & 0.34 & 0.36 & 0.71 & 0.38 & 0.72 & 0.53 & 0.69 & 0.70 \\
\hline Worked part-time last year & 0.32 & 0.31 & 0.33 & 0.34 & 0.27 & 0.32 & 0.06 & 0.08 & 0.08 & 0.04 & 0.11 & 0.06 \\
\hline Self-employed last year & 0.06 & 0.07 & 0.04 & 0.02 & 0.06 & 0.06 & 0.11 & 0.09 & 0.11 & 0.15 & 0.08 & 0.11 \\
\hline Job security perception last year ${ }^{(a)}$ & 8.06 & 8.11 & 8.14 & 7.56 & 8.08 & 8.05 & 7.95 & 7.88 & 7.64 & 7.43 & 7.84 & 7.94 \\
\hline Work life flexibility perception last year ${ }^{(a)}$ & 7.56 & 7.74 & 7.51 & 7.40 & 7.35 & 7.55 & 7.44 & 7.61 & 7.73 & 7.35 & 7.13 & 7.44 \\
\hline Overall job satisfaction last year ${ }^{\text {(a) }}$ & 7.79 & 7.88 & 7.74 & 7.76 & 7.63 & 7.79 & 7.61 & 7.43 & 7.85 & 7.57 & 7.55 & 7.61 \\
\hline Age & 45.45 & 47.48 & 47.41 & 51.52 & 48.98 & 45.77 & 45.86 & 47.68 & 44.27 & 47.43 & 50.04 & 45.98 \\
\hline Immigrant from an ESB country & 0.10 & 0.06 & 0.07 & 0.02 & 0.05 & 0.10 & 0.12 & 0.09 & 0.12 & 0.09 & 0.10 & 0.12 \\
\hline Immigrant from a northwest Europe NESB country & 0.02 & 0.02 & 0.00 & 0.02 & 0.03 & 0.02 & 0.01 & 0.01 & 0.00 & 0.04 & 0.01 & 0.01 \\
\hline Immigrant from a NESB country (other) & 0.11 & 0.12 & 0.16 & 0.18 & 0.09 & 0.11 & 0.11 & 0.09 & 0.09 & 0.09 & 0.07 & 0.11 \\
\hline Child immigrant & 0.44 & 0.59 & 0.30 & 0.61 & 0.55 & 0.45 & 0.43 & 0.79 & 0.83 & 0.90 & 0.51 & 0.44 \\
\hline Year 12 & 0.15 & 0.11 & 0.20 & 0.11 & 0.09 & 0.14 & 0.12 & 0.07 & 0.02 & 0.13 & 0.09 & 0.12 \\
\hline Vocational training & 0.35 & 0.26 & 0.41 & 0.39 & 0.48 & 0.35 & 0.48 & 0.43 & 0.55 & 0.37 & 0.54 & 0.48 \\
\hline Bachelor or higher & 0.21 & 0.15 & 0.13 & 0.14 & 0.20 & 0.20 & 0.20 & 0.07 & 0.12 & 0.24 & 0.21 & 0.19 \\
\hline Married/de facto & 0.77 & 0.75 & 0.77 & 0.74 & 0.79 & 0.77 & 0.77 & 0.76 & 0.82 & 0.73 & 0.84 & 0.77 \\
\hline Separated/divorced/widowed & 0.13 & 0.15 & 0.07 & 0.15 & 0.11 & 0.13 & 0.08 & 0.10 & 0.01 & 0.19 & 0.11 & 0.08 \\
\hline Disable & 0.20 & 0.34 & 0.34 & 0.27 & 0.25 & 0.21 & 0.20 & 0.39 & 0.26 & 0.28 & 0.21 & 0.20 \\
\hline Non-wage household income & 0.27 & 0.26 & 0.27 & 0.27 & 0.27 & 0.27 & 0.11 & 0.15 & 0.16 & 0.11 & 0.12 & 0.11 \\
\hline Home owner without mortgage & 0.46 & 0.37 & 0.37 & 0.41 & 0.42 & 0.45 & 0.49 & 0.25 & 0.38 & 0.44 & 0.36 & 0.48 \\
\hline Home owner with mortgage & 0.32 & 0.31 & 0.38 & 0.39 & 0.40 & 0.33 & 0.29 & 0.48 & 0.36 & 0.32 & 0.45 & 0.30 \\
\hline Number of persons aged $0-4$ & 0.22 & 0.14 & 0.08 & 0.03 & 0.08 & 0.20 & 0.21 & 0.15 & 0.17 & 0.27 & 0.17 & 0.21 \\
\hline Number of persons aged 5-9 & 0.23 & 0.31 & 0.28 & 0.09 & 0.15 & 0.23 & 0.22 & 0.12 & 0.38 & 0.12 & 0.14 & 0.22 \\
\hline Number of persons aged 10-14 & 0.26 & 0.38 & 0.54 & 0.17 & 0.24 & 0.27 & 0.25 & 0.22 & 0.55 & 0.19 & 0.18 & 0.25 \\
\hline Number of persons aged 15-23 & 0.36 & 0.44 & 0.58 & 0.60 & 0.50 & 0.37 & 0.33 & 0.34 & 0.47 & 0.28 & 0.35 & 0.33 \\
\hline Number of persons aged 24-64 & 0.83 & 0.91 & 1.12 & 0.67 & 0.84 & 0.83 & 0.87 & 0.89 & 1.21 & 0.72 & 0.87 & 0.87 \\
\hline Number of elderly & 0.06 & 0.19 & 0.38 & 0.14 & 0.03 & 0.07 & 0.04 & 0.30 & 0.23 & 0.00 & 0.02 & 0.05 \\
\hline Death of close relative & 0.12 & 0.14 & 0.15 & 0.11 & 0.13 & 0.12 & 0.11 & 0.11 & 0.14 & 0.15 & 0.11 & 0.11 \\
\hline Death of close friend & 0.08 & 0.11 & 0.09 & 0.11 & 0.09 & 0.08 & 0.09 & 0.14 & 0.06 & 0.09 & 0.15 & 0.09 \\
\hline Injury to self & 0.06 & 0.12 & 0.05 & 0.10 & 0.06 & 0.07 & 0.07 & 0.07 & 0.09 & 0.10 & 0.08 & 0.08 \\
\hline Injury/illness of relative/family member & 0.16 & 0.31 & 0.19 & 0.30 & 0.31 & 0.18 & 0.13 & 0.26 & 0.25 & 0.23 & 0.27 & 0.14 \\
\hline Weekly hours of care ${ }^{(b)}$ & 0.52 & 18.96 & 13.18 & 11.14 & 6.37 & 1.80 & 0.29 & 25.96 & 5.19 & 8.04 & 4.66 & 1.11 \\
\hline Carer benefit recipient & 0.02 & 0.63 & 0.47 & 0.26 & 0.03 & 0.05 & 0.00 & 0.51 & 0.06 & 0.13 & 0.01 & 0.02 \\
\hline Number of wave-observations & 13009 & 563 & 84 & 250 & 500 & 14406 & 11800 & 242 & 146 & 76 & 252 & 12516 \\
\hline
\end{tabular}

Notes: Longitudinal sampling weights are used. ${ }^{(a)}$ Mean is for those working last year. ${ }^{(b)}$ Mean is for individuals with a valid answer to the question on the number of weekly hours spent on

providing care to a spouse or relative or parents from the self-completed questionnaire. 
Appendix Table A3: Correlation matrix of work characteristics

\begin{tabular}{|c|c|c|c|c|c|c|c|c|c|c|c|c|c|c|c|c|c|c|c|c|}
\hline & \multirow[b]{2}{*}{ Job characteristics } & \multirow{2}{*}{$\begin{array}{l}\text { Var. } \\
\text { code }\end{array}$} & \multicolumn{4}{|c|}{ Work security } & \multicolumn{8}{|c|}{ Flexibility } & \multicolumn{5}{|c|}{ Entitlements } & \multirow{2}{*}{$\begin{array}{c}\text { Overall } \\
18 \\
\end{array}$} \\
\hline & & & 1 & 2 & 3 & 4 & 5 & 6 & 7 & 8 & 9 & 10 & 11 & 12 & 13 & 14 & 15 & 16 & 17 & \\
\hline \multirow{4}{*}{ 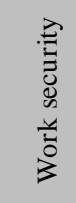 } & Per cent chance of losing job in next 12 months ${ }^{(a)}$ & 1 & 1.00 & & & & & & & & & & & & & & & & & \\
\hline & Per cent chance of voluntarily leaving job in next 12 months ${ }^{(a)}$ & 2 & 0.23 & 1.00 & & & & & & & & & & & & & & & & \\
\hline & Job security satisfaction ${ }^{(b)}$ & 3 & -0.58 & -0.16 & 1.00 & & & & & & & & & & & & & & & \\
\hline & I have a secure future in my job ${ }^{(c)}$ & 4 & -0.48 & -0.20 & 0.67 & 1.00 & & & & & & & & & & & & & & \\
\hline \multirow{8}{*}{ 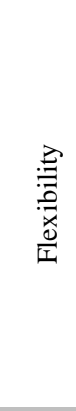 } & The flexibility to balance work and non-work commitments satisfaction (b) & 5 & -0.10 & -0.14 & 0.22 & 0.16 & 1.00 & & & & & & & & & & & & & \\
\hline & My working times can be flexible ${ }^{(c)}$ & 6 & & -0.03 & 0.04 & 0.08 & 0.43 & 1.00 & & & & & & & & & & & & \\
\hline & I can decide when to take a break ${ }^{(\mathrm{c})}$ & 7 & -0.02 & & 0.08 & 0.09 & 0.31 & 0.58 & 1.00 & & & & & & & & & & & \\
\hline & I have a lot of choice in deciding what I do at work ${ }^{(c)}$ & 8 & -0.07 & -0.07 & 0.12 & 0.16 & 0.25 & 0.48 & 0.49 & 1.00 & & & & & & & & & & \\
\hline & I have a lot of freedom to decide when I do my work ${ }^{(c)}$ & 9 & -0.02 & -0.04 & 0.06 & 0.08 & 0.35 & 0.66 & 0.57 & 0.69 & 1.00 & & & & & & & & & \\
\hline & Workplace entitlements: Flexible start/finish times ${ }^{(\mathrm{d})}$ & 10 & 0.03 & & & & 0.29 & 0.57 & 0.46 & 0.31 & 0.44 & 1.00 & & & & & & & & \\
\hline & Workplace entitlements: Home-based work ${ }^{(\mathrm{d})}$ & 11 & 0.02 & & & 0.02 & 0.18 & 0.39 & 0.35 & 0.28 & 0.37 & 0.47 & 1.00 & & & & & & & \\
\hline & Workplace entitlements: Permanent part-time work ${ }^{(\mathrm{d})}$ & 12 & -0.08 & -0.06 & 0.14 & 0.16 & 0.05 & & -0.02 & -0.05 & -0.05 & 0.14 & 0.14 & 1.00 & & & & & & \\
\hline \multirow{5}{*}{ 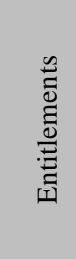 } & Does employer provide paid sick leave $\mathrm{d}^{(\mathrm{d})}$ & 13 & -0.12 & -0.09 & 0.16 & 0.17 & -0.11 & -0.12 & 0.04 & 0.06 & -0.05 & & 0.08 & 0.14 & 1.00 & & & & & \\
\hline & Does employer provide paid holiday leave ${ }^{(\mathrm{d})}$ & 14 & -0.12 & -0.09 & 0.16 & 0.18 & -0.10 & -0.12 & 0.04 & 0.06 & -0.05 & & 0.08 & 0.14 & 0.96 & 1.00 & & & & \\
\hline & Child care facilities or subsidised child care expenses ${ }^{(\mathrm{d})}$ & 15 & & & 0.02 & 0.02 & 0.05 & 0.09 & 0.06 & 0.03 & 0.06 & 0.15 & 0.20 & 0.13 & 0.04 & 0.03 & 1.00 & & & \\
\hline & Workplace entitlements: Special leave for caring for family member ${ }^{(\mathrm{d})}$ & 16 & -0.09 & -0.09 & 0.14 & 0.17 & & -0.07 & -0.02 & -0.06 & -0.11 & 0.09 & 0.09 & 0.48 & 0.44 & 0.43 & 0.15 & 1.00 & & \\
\hline & Workplace entitlements: Paid maternity leave ${ }^{(\mathrm{d})}$ & 17 & -0.07 & -0.09 & 0.10 & 0.12 & -0.06 & -0.13 & -0.09 & -0.12 & -0.17 & 0.03 & 0.08 & 0.38 & 0.40 & 0.39 & 0.22 & 0.60 & 1.00 & \\
\hline & Overall job satisfaction ${ }^{(\mathrm{b})}$ & 18 & -0.22 & -0.37 & 0.43 & 0.35 & 0.54 & 0.21 & 0.17 & 0.23 & 0.20 & 0.11 & 0.05 & 0.07 & & & 0.03 & 0.07 & 0.02 & 1.00 \\
\hline
\end{tabular}

Notes: Only correlation coefficients significant at the $5 \%$ level or better are listed. Longitudinal sampling weights are used.

(a) a number between 0 and 100 ; ${ }^{(b)}$ a number between 0 (totally dissatisfied) and 10 (totally satisfied); ${ }^{\text {(c) }}$ a number between 1 (strongly disagree) and 7 (strongly agree); ${ }^{(\mathrm{d})}$ Yes/No choice, Yes = 1 and No $=0$. 


\begin{tabular}{|c|c|c|c|c|c|c|c|c|c|c|}
\hline & \multirow[b]{2}{*}{ Variables } & \multicolumn{3}{|c|}{ Pooled sample } & \multicolumn{3}{|c|}{ Females } & \multicolumn{3}{|c|}{ Males } \\
\hline & & FT & $\mathrm{PT}$ & SE & FT & $\mathrm{PT}$ & $\mathrm{SE}$ & FT & PT & $\mathrm{SE}$ \\
\hline \multirow{4}{*}{ 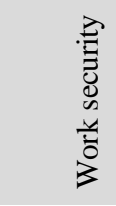 } & Per cent chance of losing job in next 12 months ${ }^{(a)}$ & 8.81 & 10.01 & & 7.72 & 9.26 & & 9.41 & 14.03 & \\
\hline & Per cent chance of voluntarily leaving job in next 12 months ${ }^{(a)}$ & 15.94 & 17.93 & & 14.87 & 16.91 & & 16.54 & 23.33 & \\
\hline & Job security satisfaction ${ }^{(b)}$ & 8.10 & 7.88 & 7.38 & 8.18 & 7.98 & 7.58 & 8.06 & 7.39 & 7.27 \\
\hline & I have a secure future in my job (c) & 5.24 & 5.06 & 4.78 & 5.39 & 5.13 & 5.00 & 5.17 & 4.70 & 4.68 \\
\hline \multirow{8}{*}{ 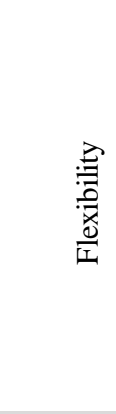 } & The flexibility to balance work and non-work commitments satisfaction (b) & 7.24 & 8.06 & 7.86 & 7.03 & 8.05 & 8.06 & 7.35 & 8.14 & 7.74 \\
\hline & My working times can be flexible ${ }^{(c)}$ & 3.97 & 4.29 & 5.57 & 3.66 & 4.21 & 5.73 & 4.12 & 4.67 & 5.49 \\
\hline & I can decide when to take a break ${ }^{(c)}$ & 4.79 & 4.33 & 5.89 & 4.44 & 4.25 & 5.83 & 4.96 & 4.75 & 5.92 \\
\hline & I have a lot of choice in deciding what I do at work ${ }^{(c)}$ & 3.86 & 3.45 & 5.24 & 3.63 & 3.40 & 5.28 & 3.98 & 3.72 & 5.22 \\
\hline & I have a lot of freedom to decide when I do my work ${ }^{(\mathrm{c})}$ & 3.66 & 3.60 & 5.39 & 3.40 & 3.52 & 5.60 & 3.80 & 3.99 & 5.29 \\
\hline & Workplace entitlements: Flexible start/finish times ${ }^{(d)}$ & 0.57 & 0.54 & 0.76 & 0.52 & 0.53 & 0.77 & 0.59 & 0.58 & 0.76 \\
\hline & Workplace entitlements: Home-based work ${ }^{(d)}$ & 0.28 & 0.20 & 0.46 & 0.26 & 0.20 & 0.56 & 0.29 & 0.25 & 0.41 \\
\hline & Workplace entitlements: Permanent part-time work ${ }^{(\mathrm{d})}$ & 0.76 & 0.85 & 0.42 & 0.87 & 0.87 & 0.49 & 0.70 & 0.77 & 0.38 \\
\hline \multirow{5}{*}{ 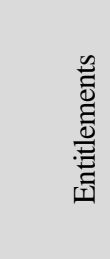 } & Does employer provide paid sick leave ${ }^{(d)}$ & 0.93 & 0.58 & & 0.93 & 0.61 & & 0.92 & 0.43 & \\
\hline & Does employ er provide paid holiday leave ${ }^{(\mathrm{d})}$ & 0.92 & 0.58 & & 0.92 & 0.60 & & 0.92 & 0.43 & \\
\hline & Child care facilities or subsidised child care expenses ${ }^{(\mathrm{d})}$ & 0.09 & 0.09 & 0.05 & 0.09 & 0.09 & 0.05 & 0.10 & 0.09 & 0.04 \\
\hline & Workplace entitlements: Special leave for caring for family member ${ }^{(d)}$ & 0.84 & 0.71 & 0.30 & 0.88 & 0.73 & 0.27 & 0.82 & 0.60 & 0.32 \\
\hline & Workplace entitlements: Paid maternity leave ${ }^{\text {(d) }}$ & 0.65 & 0.48 & 0.07 & 0.71 & 0.50 & 0.06 & 0.61 & 0.41 & 0.07 \\
\hline Overall & Overall job satisfaction ${ }^{(b)}$ & 7.63 & 7.87 & 7.66 & 7.64 & 7.91 & 7.94 & 7.62 & 7.63 & 7.51 \\
\hline
\end{tabular}

Notes: FT: full time; PT: part time; SE: self-employed. Tests for the difference of means of full time jobs are statistically significant at the $5 \%$ level for all variables except those given in bold. Longitudinal sampling weights are used.

(a) a number between 0 and 100; ${ }^{\text {(b) }}$ a number between 0 (totally dissatisfied) and 10 (totally satisfied); ${ }^{(\mathrm{c})}$ a number between 1 (strongly disagree) and 7 (strongly agree); ${ }^{(\mathrm{d})}$ Yes/No choice, Yes = 1 and No $=0$. 
Appendix Table A5: Differences between original and selected samples

\begin{tabular}{|c|c|c|c|c|}
\hline \multirow[b]{2}{*}{ Variable } & \multicolumn{2}{|c|}{ Female } & \multicolumn{2}{|c|}{ Male } \\
\hline & $\begin{array}{l}\text { Resident/non- } \\
\text { resident care }\end{array}$ & $\begin{array}{l}\text { Main/secondary } \\
\text { care }\end{array}$ & $\begin{array}{l}\text { Resident/non- } \\
\text { resident care }\end{array}$ & $\begin{array}{l}\text { Main/secondary } \\
\text { care }\end{array}$ \\
\hline Age & $0.01^{* * *}$ & $0.01^{* * *}$ & $0.01^{* * *}$ & $0.01^{* * *}$ \\
\hline Immigrant from an ESB country ${ }^{(a)}$ & -0.01 & -0.01 & $-0.02 *$ & $-0.02 *$ \\
\hline Immigrant from a northwest Europe NESB country ${ }^{(a)}$ & 0.01 & 0.01 & $-0.14 * * *$ & $-0.14 * * *$ \\
\hline Immigrant from a NESB country (other) ${ }^{\left({ }^{(a)}\right.}$ & $-0.12 * * *$ & $-0.12 * * *$ & $-0.09 * * *$ & $-0.09 * * *$ \\
\hline Year $12^{(\mathrm{b})}$ & 0.01 & 0.01 & $0.05 * * *$ & $0.05 * * *$ \\
\hline Vocational training $^{(\mathrm{D})}$ & $-0.02 * *$ & $-0.02 * *$ & $0.04^{* * *}$ & $0.04^{* * *}$ \\
\hline Bachelor or higher ${ }^{(\mathrm{D})}$ & $0.02 *$ & $0.02 *$ & $0.04 * * *$ & $0.04^{* * *}$ \\
\hline Married/de facto ${ }^{(c)}$ & $0.08 * * *$ & $0.08^{* * *}$ & $0.05 * * *$ & $0.05^{* * *}$ \\
\hline Separated/divorced/widowed ${ }^{(c)}$ & $-0.06 * * *$ & $-0.05 * * *$ & 0.02 & 0.02 \\
\hline Disable & $-0.01 * *$ & $-0.01 *$ & $-0.02 * *$ & $-0.02 * *$ \\
\hline Non-wage household income & $-0.06 * * *$ & $-0.06 * * *$ & $-0.09 * * *$ & $-0.09 * * *$ \\
\hline Home owner without mortgage ${ }^{(d)}$ & $0.10 * * *$ & $0.10 * * *$ & $0.12 * * *$ & $0.12 * * *$ \\
\hline Home owner with mortgage ${ }^{\text {(d) }}$ & $0.09 * * *$ & $0.09 * * *$ & $0.09 * * *$ & $0.09 * * *$ \\
\hline Number of persons aged $0-4$ & 0.01 & 0.01 & $0.01 * *$ & $0.01 * *$ \\
\hline Number of persons aged 5-9 & $0.02 * * *$ & $0.02 * * *$ & $0.03 * * *$ & $0.03^{* * *}$ \\
\hline Number of persons aged 10-14 & $0.04 * * *$ & $0.04 * * *$ & $0.04 * * *$ & $0.04 * * *$ \\
\hline Number of persons aged 15-23 & $0.04 * * *$ & $0.04 * * *$ & $0.02 * * *$ & $0.02 * * *$ \\
\hline Number of persons aged 24-64 & $-0.05 * * *$ & $-0.05 * * *$ & $-0.02 * *$ & $-0.02 * *$ \\
\hline Number of elderly & $-0.18 * * *$ & $-0.18 * * *$ & $-0.07 * * *$ & $-0.07 * * *$ \\
\hline Death of close relative & $-0.02 * *$ & $-0.02 * *$ & -0.01 & -0.01 \\
\hline Death of close friend & $-0.05 * * *$ & $-0.05 * * *$ & $-0.03 * *$ & $-0.03 * *$ \\
\hline Injury to self & $-0.04 * * *$ & $-0.04 * * *$ & $-0.04 * * *$ & $-0.04 * * *$ \\
\hline Injury/illness of relative/family member & $-0.02 * *$ & $-0.02 * *$ & 0.00 & 0.00 \\
\hline Resident carer ${ }^{(\mathrm{e})}$ & 0.00 & & 0.01 & \\
\hline Non-resident carer ${ }^{(e)}$ & 0.00 & & 0.00 & \\
\hline Main carer ${ }^{(\mathrm{e})}$ & & -0.01 & & 0.01 \\
\hline Secondary carer ${ }^{(\mathrm{e})}$ & & 0.01 & & -0.00 \\
\hline Observations & 28,418 & 28,418 & 25,212 & 25,212 \\
\hline Pseudo R2 & 0.04 & 0.04 & 0.04 & 0.04 \\
\hline P t test & 0.97 & 0.63 & 0.92 & 0.82 \\
\hline
\end{tabular}

Notes: Results (marginal effects) are from a probit model. Marginal effects are calculated at the means of continuous variables. The dependent variable is equal to one if the individual is in our final sample and zero otherwise. ${ }^{(\mathrm{a}),(\mathrm{b}),(\mathrm{c}),(\mathrm{d}),(\mathrm{e})}$ denote native, no qualification, never married, renter, and non-carer as the base group, respectively. $\mathrm{P} t$ test: $\mathrm{P}$ value of a $\mathrm{t}$ test for whether caregiving variable estimates are equal to zero. The symbol *denotes significance at the $10 \%$ level, $* *$ at the $5 \%$ level, and $* * *$ at the $1 \%$ level. 
Appendix Table A6: Caregiving dynamics: Resident versus non-resident care - Model 1 with employment status (Coefficient estimates)

\begin{tabular}{|c|c|c|c|c|c|c|c|c|}
\hline \multirow[b]{3}{*}{ Variables } & \multicolumn{4}{|c|}{ Female } & \multicolumn{4}{|c|}{ Male } \\
\hline & \multicolumn{2}{|c|}{ Specification I } & \multicolumn{2}{|c|}{ Specification II } & \multicolumn{2}{|c|}{ Specification I } & \multicolumn{2}{|c|}{ Specification II } \\
\hline & $\begin{array}{l}\text { Resident } \\
\text { care }\end{array}$ & $\begin{array}{c}\text { Non- } \\
\text { resident } \\
\text { care } \\
\end{array}$ & $\begin{array}{l}\text { Resident } \\
\text { care }\end{array}$ & $\begin{array}{c}\text { Non- } \\
\text { resident } \\
\text { care } \\
\end{array}$ & $\begin{array}{l}\text { Resident } \\
\text { care }\end{array}$ & $\begin{array}{c}\text { Non- } \\
\text { resident } \\
\text { care } \\
\end{array}$ & $\begin{array}{l}\text { Resident } \\
\text { care }\end{array}$ & $\begin{array}{c}\text { Non- } \\
\text { resident } \\
\text { care }\end{array}$ \\
\hline Resident care last year ${ }^{(a)}$ & $\begin{array}{l}1.91 * * * \\
(0.22)\end{array}$ & $\begin{array}{l}0.57 \\
(0.39)\end{array}$ & $\begin{array}{l}1.89 * * * \\
(0.22)\end{array}$ & $\begin{array}{l}0.40 \\
(0.40)\end{array}$ & $\begin{array}{l}1.50^{* * *} \\
(0.29)\end{array}$ & $\begin{array}{l}-0.21 \\
(0.60)\end{array}$ & $\begin{array}{l}1.52^{* * *} \\
(0.29)\end{array}$ & $\begin{array}{l}0.03 \\
(0.62)\end{array}$ \\
\hline Non-resident care last year ${ }^{(a)}$ & $\begin{array}{l}0.39 \\
(0.41)\end{array}$ & $\begin{array}{l}1.27 * * * \\
(0.16)\end{array}$ & $\begin{array}{l}0.26 \\
(0.41)\end{array}$ & $\begin{array}{l}1.27 * * * \\
(0.16)\end{array}$ & $\begin{array}{l}0.47 \\
(0.58)\end{array}$ & $\begin{array}{l}1.32 * * * \\
(0.25)\end{array}$ & $\begin{array}{l}0.74 \\
(0.59)\end{array}$ & $\begin{array}{l}1.18^{* * *} \\
(0.25)\end{array}$ \\
\hline Resident care at $\mathrm{t}=1^{\text {(a) }}$ & $\begin{array}{l}4.79 * * * \\
(0.51)\end{array}$ & $\begin{array}{l}0.15 \\
(0.44)\end{array}$ & $\begin{array}{l}4.82^{* * * *} \\
(0.51)\end{array}$ & $\begin{array}{l}0.34 \\
(0.46)\end{array}$ & $\begin{array}{l}5.69 * * * \\
(0.70)\end{array}$ & $\begin{array}{l}1.35 * * \\
(0.62)\end{array}$ & $\begin{array}{l}5.69 * * * \\
(0.70)\end{array}$ & $\begin{array}{l}1.34 * * \\
(0.54)\end{array}$ \\
\hline Non-resident care at $\mathrm{t}=1^{\text {(a) }}$ & $\begin{array}{l}0.74 \\
(0.51)\end{array}$ & $\begin{array}{l}2.62 * * * \\
(0.29)\end{array}$ & $\begin{array}{l}0.84 * \\
(0.51)\end{array}$ & $\begin{array}{l}2.62 * * * \\
(0.28)\end{array}$ & $\begin{array}{l}2.13^{* * *} \\
(0.67)\end{array}$ & $\begin{array}{l}2.45^{* * * *} \\
(0.40)\end{array}$ & $\begin{array}{l}2.06^{* * * *} \\
(0.67)\end{array}$ & $\begin{array}{l}2.56^{* * *} \\
(0.39)\end{array}$ \\
\hline Work full timelast year ${ }^{(\mathrm{b})}$ & $\begin{array}{l}-1.17^{* * *} \\
(0.34)\end{array}$ & $\begin{array}{l}-0.50 * * \\
(0.23)\end{array}$ & $\begin{array}{l}-1.18^{* * * *} \\
(0.34)\end{array}$ & $\begin{array}{l}-0.51 * * \\
(0.23)\end{array}$ & $\begin{array}{l}-0.99 * * \\
(0.42)\end{array}$ & $\begin{array}{l}-0.03 \\
(0.35)\end{array}$ & $\begin{array}{l}-1.00^{* *} \\
(0.42)\end{array}$ & $\begin{array}{l}-0.02 \\
(0.36)\end{array}$ \\
\hline Work part time last year ${ }^{(\mathrm{b})}$ & $\begin{array}{l}-0.22 \\
(0.27)\end{array}$ & $\begin{array}{l}-0.20 \\
(0.20)\end{array}$ & $\begin{array}{l}-0.22 \\
(0.27)\end{array}$ & $\begin{array}{l}-0.20 \\
(0.19)\end{array}$ & $\begin{array}{l}-1.07^{* *} \\
(0.53)\end{array}$ & $\begin{array}{l}0.72 * \\
(0.40)\end{array}$ & $\begin{array}{l}-1.07^{* *} \\
(0.53)\end{array}$ & $\begin{array}{l}0.68 * \\
(0.41)\end{array}$ \\
\hline Self-employed last year ${ }^{(\mathrm{b})}$ & $\begin{array}{l}-0.09 \\
(0.46)\end{array}$ & $\begin{array}{l}-0.38 \\
(0.36)\end{array}$ & $\begin{array}{l}-0.11 \\
(0.48)\end{array}$ & $\begin{array}{l}-0.37 \\
(0.36)\end{array}$ & $\begin{array}{l}-1.31^{* *} \\
(0.56)\end{array}$ & $\begin{array}{l}0.26 \\
(0.45)\end{array}$ & $\begin{array}{l}-1.32 * * \\
(0.56)\end{array}$ & $\begin{array}{l}0.28 \\
(0.45)\end{array}$ \\
\hline Work full timeat $\mathrm{t}=1^{(\mathrm{D})}$ & $\begin{array}{l}-0.47 \\
(0.38)\end{array}$ & $\begin{array}{l}0.28 \\
(0.27)\end{array}$ & $\begin{array}{l}-0.45 \\
(0.39)\end{array}$ & $\begin{array}{l}0.27 \\
(0.27)\end{array}$ & $\begin{array}{l}-0.24 \\
(0.59)\end{array}$ & $\begin{array}{l}-0.20 \\
(0.42)\end{array}$ & $\begin{array}{l}-0.21 \\
(0.58)\end{array}$ & $\begin{array}{l}-0.16 \\
(0.42)\end{array}$ \\
\hline Work part time at $\mathrm{t}=1^{\text {(b) }}$ & $\begin{array}{l}-0.67^{*} \\
(0.35)\end{array}$ & $\begin{array}{l}0.19 \\
(0.24)\end{array}$ & $\begin{array}{l}-0.64 * \\
(0.35)\end{array}$ & $\begin{array}{l}0.17 \\
(0.24)\end{array}$ & $\begin{array}{l}-1.17 \\
(0.86)\end{array}$ & $\begin{array}{l}-1.44^{* *} \\
(0.65)\end{array}$ & $\begin{array}{l}-1.14 \\
(0.86)\end{array}$ & $\begin{array}{l}-1.42 * * \\
(0.67)\end{array}$ \\
\hline Self-employed at $t=1^{\text {(D) }}$ & $\begin{array}{l}-0.70 \\
(0.62)\end{array}$ & $\begin{array}{l}-0.38 \\
(0.42)\end{array}$ & $\begin{array}{l}-0.65 \\
(0.67)\end{array}$ & $\begin{array}{l}-0.42 \\
(0.42)\end{array}$ & $\begin{array}{l}-0.47 \\
(0.72)\end{array}$ & $\begin{array}{l}-0.91^{*} \\
(0.53)\end{array}$ & $\begin{array}{l}-0.40 \\
(0.72)\end{array}$ & $\begin{array}{l}-0.88 \\
(0.54)\end{array}$ \\
\hline Age & $\begin{array}{l}-0.26 \\
(0.33)\end{array}$ & $\begin{array}{l}-0.02 \\
(0.25)\end{array}$ & $\begin{array}{l}-0.25 \\
(0.33)\end{array}$ & $\begin{array}{l}-0.02 \\
(0.25)\end{array}$ & $\begin{array}{l}-0.40 \\
(0.40)\end{array}$ & $\begin{array}{l}0.01 \\
(0.35)\end{array}$ & $\begin{array}{l}-0.38 \\
(0.40)\end{array}$ & $\begin{array}{l}0.01 \\
(0.36)\end{array}$ \\
\hline Age squared & $\begin{array}{l}-0.00 \\
(0.00)\end{array}$ & $\begin{array}{l}-0.00 * * \\
(0.00)\end{array}$ & $\begin{array}{l}-0.00 \\
(0.00)\end{array}$ & $\begin{array}{l}-0.00 * * \\
(0.00)\end{array}$ & $\begin{array}{l}0.00 \\
(0.00)\end{array}$ & $\begin{array}{l}-0.00 \\
(0.00)\end{array}$ & $\begin{array}{l}0.01 \\
(0.00)\end{array}$ & $\begin{array}{l}-0.00 \\
(0.00)\end{array}$ \\
\hline ESB immigrant ${ }^{(c)}$ & $\begin{array}{l}-0.58 \\
(0.47)\end{array}$ & $\begin{array}{l}-0.51 \\
(0.37)\end{array}$ & $\begin{array}{l}-0.61 \\
(0.47)\end{array}$ & $\begin{array}{l}-0.56^{*} \\
(0.33)\end{array}$ & $\begin{array}{l}0.60 \\
(0.45)\end{array}$ & $\begin{array}{l}0.08 \\
(0.35)\end{array}$ & $\begin{array}{l}0.63 \\
(0.45)\end{array}$ & $\begin{array}{l}0.10 \\
(0.36)\end{array}$ \\
\hline NESB immigrant (northwest Europe) ${ }^{\text {(c) }}$ & $\begin{array}{l}-0.44 \\
(0.96)\end{array}$ & $\begin{array}{l}-0.11 \\
(0.54)\end{array}$ & $\begin{array}{l}-0.44 \\
(0.95)\end{array}$ & $\begin{array}{l}-0.10 \\
(0.55)\end{array}$ & $\begin{array}{l}0.79 \\
(1.21)\end{array}$ & $\begin{array}{l}0.34 \\
(0.75)\end{array}$ & $\begin{array}{l}0.85 \\
(1.20)\end{array}$ & $\begin{array}{l}0.35 \\
(0.73)\end{array}$ \\
\hline NESB immigrant (other) ${ }^{(\mathrm{c})}$ & $\begin{array}{l}-0.30 \\
(0.53)\end{array}$ & $\begin{array}{l}0.43 \\
(0.35)\end{array}$ & $\begin{array}{l}-0.31 \\
(0.53)\end{array}$ & $\begin{array}{l}0.44 \\
(0.34)\end{array}$ & $\begin{array}{l}0.73 \\
(0.65)\end{array}$ & $\begin{array}{l}0.96^{* *} \\
(0.41)\end{array}$ & $\begin{array}{l}0.74 \\
(0.65)\end{array}$ & $\begin{array}{l}0.95 * * \\
(0.43)\end{array}$ \\
\hline Child immigrant & $\begin{array}{l}0.44 \\
(0.55)\end{array}$ & $\begin{array}{l}0.75^{*} \\
(0.39)\end{array}$ & $\begin{array}{l}0.45 \\
(0.55)\end{array}$ & $\begin{array}{l}0.78 * * \\
(0.38)\end{array}$ & $\begin{array}{l}1.34 * * \\
(0.67)\end{array}$ & $\begin{array}{l}1.06^{* *} \\
(0.42)\end{array}$ & $\begin{array}{l}1.31^{* *} \\
(0.66)\end{array}$ & $\begin{array}{l}1.07 * * \\
(0.43)\end{array}$ \\
\hline Year $12^{\text {(d) }}$ & $\begin{array}{l}-0.03 \\
(0.38)\end{array}$ & $\begin{array}{l}-0.03 \\
(0.27)\end{array}$ & $\begin{array}{l}-0.03 \\
(0.38)\end{array}$ & $\begin{array}{l}0.01 \\
(0.26)\end{array}$ & $\begin{array}{l}-0.33 \\
(0.56)\end{array}$ & $\begin{array}{l}-0.25 \\
(0.40)\end{array}$ & $\begin{array}{l}-0.38 \\
(0.56)\end{array}$ & $\begin{array}{l}-0.24 \\
(0.39)\end{array}$ \\
\hline Vocational training $^{(\mathrm{d})}$ & $\begin{array}{l}0.05 \\
(0.28)\end{array}$ & $\begin{array}{l}0.33^{*} \\
(0.18)\end{array}$ & $\begin{array}{l}0.07 \\
(0.29)\end{array}$ & $\begin{array}{l}0.34^{*} \\
(0.18)\end{array}$ & $\begin{array}{l}-0.30 \\
(0.34)\end{array}$ & $\begin{array}{l}0.09 \\
(0.26)\end{array}$ & $\begin{array}{l}-0.34 \\
(0.34)\end{array}$ & $\begin{array}{l}0.08 \\
(0.26)\end{array}$ \\
\hline Bachelor or higher ${ }^{\text {(d) }}$ & $\begin{array}{l}-0.01 \\
(0.37)\end{array}$ & $\begin{array}{l}-0.04 \\
(0.24)\end{array}$ & $\begin{array}{l}-0.01 \\
(0.37)\end{array}$ & $\begin{array}{l}-0.04 \\
(0.24)\end{array}$ & $\begin{array}{l}-1.01^{* *} \\
(0.49)\end{array}$ & $\begin{array}{l}0.11 \\
(0.32)\end{array}$ & $\begin{array}{l}-1.03 * * \\
(0.48)\end{array}$ & $\begin{array}{l}0.11 \\
(0.32)\end{array}$ \\
\hline Married/de facto ${ }^{(e)}$ & $\begin{array}{l}-1.10 \\
(0.95)\end{array}$ & $\begin{array}{l}-0.63 \\
(0.77)\end{array}$ & $\begin{array}{l}-1.09 \\
(0.95)\end{array}$ & $\begin{array}{l}-0.65 \\
(0.77)\end{array}$ & $\begin{array}{l}-0.94 \\
(0.96)\end{array}$ & $\begin{array}{l}1.18 \\
(1.09)\end{array}$ & $\begin{array}{l}-0.97 \\
(0.96)\end{array}$ & $\begin{array}{l}1.23 \\
(1.11)\end{array}$ \\
\hline Separated/divorced/widowed ${ }^{(e)}$ & $\begin{array}{l}-0.59 \\
(1.05)\end{array}$ & $\begin{array}{l}-0.63 \\
(0.77)\end{array}$ & $\begin{array}{l}-0.57 \\
(1.05)\end{array}$ & $\begin{array}{l}-0.65 \\
(0.77)\end{array}$ & $\begin{array}{l}-2.33^{*} \\
(1.38)\end{array}$ & $\begin{array}{l}1.18 \\
(1.09)\end{array}$ & $\begin{array}{l}-2.35^{*} \\
(1.38)\end{array}$ & $\begin{array}{l}1.23 \\
(1.11)\end{array}$ \\
\hline Disable & $\begin{array}{l}0.35 \\
(0.23)\end{array}$ & $\begin{array}{l}0.31^{*} \\
(0.18)\end{array}$ & $\begin{array}{l}0.35 \\
(0.23)\end{array}$ & $\begin{array}{l}0.31^{*} \\
(0.18)\end{array}$ & $\begin{array}{l}-0.19 \\
(0.28)\end{array}$ & $\begin{array}{l}0.23 \\
(0.26)\end{array}$ & $\begin{array}{l}-0.19 \\
(0.28)\end{array}$ & $\begin{array}{l}0.23 \\
(0.26)\end{array}$ \\
\hline Non-wage household income & $\begin{array}{l}0.23 \\
(0.57)\end{array}$ & $\begin{array}{l}-0.06 \\
(0.29)\end{array}$ & $\begin{array}{l}0.25 \\
(0.56)\end{array}$ & $\begin{array}{l}-0.06 \\
(0.29)\end{array}$ & $\begin{array}{l}0.10 \\
(0.80)\end{array}$ & $\begin{array}{l}0.75 \\
(0.70)\end{array}$ & $\begin{array}{l}0.09 \\
(0.80)\end{array}$ & $\begin{array}{l}0.75 \\
(0.70)\end{array}$ \\
\hline Home owner with mortgage ${ }^{(\mathrm{t})}$ & $\begin{array}{l}1.14^{* *} \\
(0.45)\end{array}$ & $\begin{array}{l}0.32 \\
(0.35)\end{array}$ & $\begin{array}{l}1.14 * * \\
(0.45)\end{array}$ & $\begin{array}{l}0.34 \\
(0.35)\end{array}$ & $\begin{array}{l}0.27 \\
(0.53)\end{array}$ & $\begin{array}{l}-0.63^{*} \\
(0.38)\end{array}$ & $\begin{array}{l}0.27 \\
(0.53)\end{array}$ & $\begin{array}{l}-0.62 \\
(0.38)\end{array}$ \\
\hline Home owner without mortgage ${ }^{(t)}$ & $\begin{array}{l}0.55 \\
(0.48)\end{array}$ & $\begin{array}{l}0.32 \\
(0.38)\end{array}$ & $\begin{array}{l}0.55 \\
(0.48)\end{array}$ & $\begin{array}{l}0.33 \\
(0.38)\end{array}$ & $\begin{array}{l}0.10 \\
(0.56)\end{array}$ & $\begin{array}{l}-0.65 \\
(0.44)\end{array}$ & $\begin{array}{l}0.10 \\
(0.56)\end{array}$ & $\begin{array}{l}-0.66 \\
(0.44)\end{array}$ \\
\hline Number of persons aged 0-4 & $\begin{array}{l}0.18 \\
(0.31)\end{array}$ & $\begin{array}{l}-0.62 * * \\
(0.31)\end{array}$ & $\begin{array}{l}0.17 \\
(0.31)\end{array}$ & $\begin{array}{l}-0.61 * * \\
(0.31)\end{array}$ & $\begin{array}{l}0.60 \\
(0.38)\end{array}$ & $\begin{array}{l}-0.52 \\
(0.33)\end{array}$ & $\begin{array}{l}0.62 * \\
(0.37)\end{array}$ & $\begin{array}{l}-0.58^{*} \\
(0.34)\end{array}$ \\
\hline Number of persons aged 5-9 & $\begin{array}{l}0.41 \\
(0.27)\end{array}$ & $\begin{array}{l}-0.53^{* *} \\
(0.25)\end{array}$ & $\begin{array}{l}0.40 \\
(0.27)\end{array}$ & $\begin{array}{l}-0.53^{* *} \\
(0.25)\end{array}$ & $\begin{array}{l}0.60 * \\
(0.32)\end{array}$ & $\begin{array}{l}0.11 \\
(0.32)\end{array}$ & $\begin{array}{l}0.61 * \\
(0.32)\end{array}$ & $\begin{array}{l}0.10 \\
(0.32)\end{array}$ \\
\hline Number of persons aged 10-14 & $\begin{array}{l}0.69 * * * \\
(0.23)\end{array}$ & $\begin{array}{l}-0.42^{* *} \\
(0.20)\end{array}$ & $\begin{array}{l}0.69 * * * \\
(0.23)\end{array}$ & $\begin{array}{l}-0.41 * * \\
(0.20)\end{array}$ & $\begin{array}{l}0.77 * * * \\
(0.29)\end{array}$ & $\begin{array}{l}-0.25 \\
(0.26)\end{array}$ & $\begin{array}{l}0.78^{* * * *} \\
(0.29)\end{array}$ & $\begin{array}{l}-0.26 \\
(0.26)\end{array}$ \\
\hline Number of persons aged 15-23 & $\begin{array}{l}0.35^{*} \\
(0.20)\end{array}$ & $\begin{array}{l}-0.14 \\
(0.15)\end{array}$ & $\begin{array}{l}0.35^{*} \\
(0.20)\end{array}$ & $\begin{array}{l}-0.13 \\
(0.15)\end{array}$ & $\begin{array}{l}0.46^{*} \\
(0.24)\end{array}$ & $\begin{array}{l}-0.26 \\
(0.23)\end{array}$ & $\begin{array}{l}0.46^{*} \\
(0.24)\end{array}$ & $\begin{array}{l}-0.26 \\
(0.23)\end{array}$ \\
\hline Number of persons aged 24-63 & $\begin{array}{l}1.07 * * * \\
(0.31)\end{array}$ & $\begin{array}{l}-0.02 \\
(0.27)\end{array}$ & $\begin{array}{l}1.07 * * * \\
(0.31)\end{array}$ & $\begin{array}{l}-0.02 \\
(0.27)\end{array}$ & $\begin{array}{l}1.74 * * * \\
(0.43)\end{array}$ & $\begin{array}{l}-0.71^{*} \\
(0.40)\end{array}$ & $\begin{array}{l}1.75^{* * *} \\
(0.42)\end{array}$ & $\begin{array}{l}-0.71^{*} \\
(0.40)\end{array}$ \\
\hline Number of elderly & $\begin{array}{l}2.46^{* * * *} \\
(0.42)\end{array}$ & $\begin{array}{l}-0.02 \\
(0.27)\end{array}$ & $\begin{array}{l}2.47 * * * \\
(0.43)\end{array}$ & $\begin{array}{l}-0.02 \\
(0.27)\end{array}$ & $\begin{array}{l}3.59 * * * \\
(0.63)\end{array}$ & $\begin{array}{l}-0.71 * \\
(0.40)\end{array}$ & $\begin{array}{l}3.64 * * * \\
(0.63)\end{array}$ & $\begin{array}{l}-0.71^{*} \\
(0.40)\end{array}$ \\
\hline
\end{tabular}




\begin{tabular}{|c|c|c|c|c|c|c|c|c|}
\hline \multirow[b]{3}{*}{ Variables } & \multicolumn{4}{|c|}{ Female } & \multicolumn{4}{|c|}{ Male } \\
\hline & \multicolumn{2}{|c|}{ Specification I } & \multicolumn{2}{|c|}{ Specification II } & \multicolumn{2}{|c|}{ Specification I } & \multicolumn{2}{|c|}{ Specification II } \\
\hline & $\begin{array}{c}\text { Resident } \\
\text { care }\end{array}$ & $\begin{array}{l}\text { Non- } \\
\text { resident } \\
\text { care }\end{array}$ & $\begin{array}{c}\text { Resident } \\
\text { care }\end{array}$ & $\begin{array}{l}\text { Non- } \\
\text { resident } \\
\text { care }\end{array}$ & $\begin{array}{c}\text { Resident } \\
\text { care }\end{array}$ & $\begin{array}{l}\text { Non- } \\
\text { resident } \\
\text { care }\end{array}$ & $\begin{array}{l}\text { Resident } \\
\text { care }\end{array}$ & $\begin{array}{c}\text { Non- } \\
\text { resident } \\
\text { care }\end{array}$ \\
\hline Death of close relative & $\begin{array}{l}-0.03 \\
(0.23)\end{array}$ & $\begin{array}{l}-0.74^{* * *} \\
(0.18)\end{array}$ & $\begin{array}{l}-0.04 \\
(0.23)\end{array}$ & $\begin{array}{l}-0.73^{* * *} \\
(0.18)\end{array}$ & $\begin{array}{l}-0.49 * \\
(0.30)\end{array}$ & $\begin{array}{l}-0.40 \\
(0.25)\end{array}$ & $\begin{array}{l}-0.48 \\
(0.30)\end{array}$ & $\begin{array}{l}-0.42^{*} \\
(0.25)\end{array}$ \\
\hline Death of close friend & $\begin{array}{l}0.28 \\
(0.26)\end{array}$ & $\begin{array}{l}0.05 \\
(0.19)\end{array}$ & $\begin{array}{l}0.27 \\
(0.26)\end{array}$ & $\begin{array}{l}0.06 \\
(0.19)\end{array}$ & $\begin{array}{l}0.23 \\
(0.31)\end{array}$ & $\begin{array}{l}-0.01 \\
(0.26)\end{array}$ & $\begin{array}{l}0.22 \\
(0.32)\end{array}$ & $\begin{array}{l}-0.01 \\
(0.26)\end{array}$ \\
\hline Injury to self & $\begin{array}{l}-0.28 \\
(0.27)\end{array}$ & $\begin{array}{l}-0.08 \\
(0.22)\end{array}$ & $\begin{array}{l}-0.27 \\
(0.27)\end{array}$ & $\begin{array}{l}-0.09 \\
(0.22)\end{array}$ & $\begin{array}{l}-1.04 * * \\
(0.41)\end{array}$ & $\begin{array}{l}-0.13 \\
(0.30)\end{array}$ & $\begin{array}{l}-1.03 * * \\
(0.41)\end{array}$ & $\begin{array}{l}-0.14 \\
(0.30)\end{array}$ \\
\hline Injury/illness of relative/family member & $\begin{array}{l}0.41^{* *} \\
(0.19)\end{array}$ & $\begin{array}{l}0.47 * * * \\
(0.14)\end{array}$ & $\begin{array}{l}0.42^{* *} \\
(0.19)\end{array}$ & $\begin{array}{l}0.47 * * * \\
(0.14)\end{array}$ & $\begin{array}{l}0.94 * * * \\
(0.25)\end{array}$ & $\begin{array}{l}0.65 * * * \\
(0.21)\end{array}$ & $\begin{array}{l}0.93 * * * \\
(0.25)\end{array}$ & $\begin{array}{l}0.66 * * * \\
(0.21)\end{array}$ \\
\hline
\end{tabular}

Notes: Coefficient estimates from MSL estimation with 50 Halton draws. Sample size: 12,348 person-years (2,058 persons) for females and 10,728 person-years (1,788 persons) for males. ${ }^{\text {(a) (b) (c) (d) (e) (f) }}$ indicate non-carer, unemployed, native, Year 11 or under, never married, and renter as the base group, respectively. Standard errors are in parentheses. ${ }^{* * *} \mathrm{p}<0.01, * *$ $\mathrm{p}<0.05{ }^{*} \mathrm{p}<0.1$. Estimates on the year dummies, state dummies, local variables and the initial conditions are omitted. 
Appendix Table A7: Caregiving dynamics: Resident versus non-resident care - Model 2 with work security and flexibility indicators (Coefficient estimates)

\begin{tabular}{|c|c|c|c|c|c|c|c|c|}
\hline \multirow[b]{3}{*}{ Variables } & \multicolumn{4}{|c|}{ Female } & \multicolumn{4}{|c|}{ Male } \\
\hline & \multicolumn{2}{|c|}{ Specification I } & \multicolumn{2}{|c|}{ Specification II } & \multicolumn{2}{|c|}{ Specification I } & \multicolumn{2}{|c|}{ Specification II } \\
\hline & $\begin{array}{c}\text { Resident } \\
\text { care }\end{array}$ & $\begin{array}{c}\text { Non- } \\
\text { resident } \\
\text { care } \\
\end{array}$ & $\begin{array}{l}\text { Resident } \\
\text { care }\end{array}$ & $\begin{array}{l}\text { Non- } \\
\text { resident } \\
\text { care }\end{array}$ & $\begin{array}{c}\text { Resident } \\
\text { care }\end{array}$ & $\begin{array}{l}\text { Non- } \\
\text { resident } \\
\text { care }\end{array}$ & $\begin{array}{c}\text { Resident } \\
\text { care }\end{array}$ & $\begin{array}{c}\text { Non- } \\
\text { resident } \\
\text { care }\end{array}$ \\
\hline \multirow[t]{2}{*}{ Resident care last year ${ }^{(a)}$} & $1.93^{* * *}$ & 0.58 & $1.92 * * *$ & 0.47 & $1.40^{* * *}$ & -0.12 & $1.44^{* * *}$ & 0.13 \\
\hline & $(0.24)$ & $(0.39)$ & $(0.24)$ & $(0.42)$ & $(0.30)$ & $(0.60)$ & $(0.30)$ & $(0.63)$ \\
\hline \multirow[t]{2}{*}{ Non-resident care last year ${ }^{(a)}$} & 0.35 & $1.24 * * *$ & 0.23 & $1.24^{* * *}$ & 0.20 & $1.37 * * *$ & 0.49 & $1.31^{* * *}$ \\
\hline & $(0.43)$ & $(0.17)$ & $(0.46)$ & $(0.17)$ & $(0.65)$ & $(0.26)$ & $(0.68)$ & $(0.25)$ \\
\hline \multirow[t]{2}{*}{ Resident care at $\mathrm{t}=1^{\text {(a) }}$} & $4.69 * * *$ & -0.01 & $4.72 * * *$ & 0.11 & $5.97 * * *$ & $1.60 * * *$ & $5.91 * * *$ & $1.40^{* *}$ \\
\hline & $(0.56)$ & $(0.47)$ & $(0.55)$ & $(0.51)$ & $(0.72)$ & $(0.54)$ & $(0.71)$ & $(0.55)$ \\
\hline \multirow[t]{2}{*}{ Non-resident care at $\mathrm{t}=1^{\text {(a) }}$} & 0.28 & $2.67 * * *$ & 0.26 & $2.67 * * *$ & $2.43^{* * *}$ & $2.43^{* * *}$ & $2.36 * * *$ & $2.48 * * *$ \\
\hline & $(0.72)$ & $(0.31)$ & $(0.62)$ & $(0.30)$ & (0.69) & $(0.41)$ & (0.67) & $(0.40)$ \\
\hline \multirow[t]{2}{*}{ Job security index last year } & -0.05 & -0.01 & -0.05 & -0.01 & 0.11 & 0.03 & 0.11 & 0.03 \\
\hline & $(0.06)$ & $(0.04)$ & $(0.06)$ & $(0.04)$ & $(0.07)$ & $(0.05)$ & $(0.07)$ & $(0.05)$ \\
\hline \multirow[t]{2}{*}{ Work and life job satisfaction last year } & 0.08 & -0.00 & 0.07 & -0.00 & 0.01 & -0.02 & 0.01 & -0.01 \\
\hline & $(0.06)$ & $(0.04)$ & $(0.06)$ & $(0.04)$ & $(0.07)$ & $(0.05)$ & $(0.07)$ & $(0.05)$ \\
\hline \multirow{2}{*}{ Unemployed last year } & 0.38 & 0.29 & 0.39 & 0.29 & 0.66 & -0.39 & 0.66 & -0.39 \\
\hline & $(0.25)$ & $(0.19)$ & $(0.25)$ & $(0.19)$ & $(0.42)$ & $(0.36)$ & $(0.42)$ & $(0.35)$ \\
\hline Job security index at $\mathrm{t}=1$ & $\begin{array}{l}0.08 \\
(0.08)\end{array}$ & $\begin{array}{l}-0.03 \\
(0.05)\end{array}$ & $\begin{array}{l}0.08 \\
(0.08)\end{array}$ & $\begin{array}{l}-0.03 \\
(0.05)\end{array}$ & $\begin{array}{l}-0.00 \\
(0.09)\end{array}$ & $\begin{array}{l}-0.12^{* *} \\
(0.06)\end{array}$ & $\begin{array}{l}0.00 \\
(0.09)\end{array}$ & $-0.12^{* *}$ \\
\hline Work and life job satisfaction at $\mathrm{t}=1$ & $\begin{array}{l}-0.04 \\
(0.08)\end{array}$ & $\begin{array}{l}-0.01 \\
(0.05)\end{array}$ & $\begin{array}{l}-0.04 \\
(0.08)\end{array}$ & $\begin{array}{l}-0.01 \\
(0.05)\end{array}$ & $\begin{array}{l}-0.04 \\
(0.08)\end{array}$ & $\begin{array}{l}0.01 \\
(0.06)\end{array}$ & $\begin{array}{l}-0.04 \\
(0.08)\end{array}$ & $\begin{array}{l}0.01 \\
(0.06)\end{array}$ \\
\hline Unemployed at $\mathrm{t}=1$ & $\begin{array}{l}0.32 \\
(0.32)\end{array}$ & $\begin{array}{l}-0.08 \\
(0.23)\end{array}$ & $\begin{array}{l}0.31 \\
(0.32)\end{array}$ & $\begin{array}{l}-0.07 \\
(0.23)\end{array}$ & $\begin{array}{l}0.90 \\
(0.57)\end{array}$ & $\begin{array}{l}0.48 \\
(0.43)\end{array}$ & $\begin{array}{l}0.88 \\
(0.57)\end{array}$ & $\begin{array}{l}0.49 \\
(0.42)\end{array}$ \\
\hline
\end{tabular}

Notes: Coefficient estimates from MSL estimation with 50 Halton draws; ${ }^{(a)}$ indicates non-carer as the base group. Standard errors in parentheses; ${ }^{* * *} \mathrm{p}<0.01,{ }^{* *} \mathrm{p}<0.05$, ${ }^{*} \mathrm{p}<0.1$. Estimates on other variables are omitted. 
Appendix Table A8: Caregiving dynamics: Resident versus non-resident care - Model 3 with overall work satisfaction indicator (Coefficient estimates)

\begin{tabular}{|c|c|c|c|c|c|c|c|c|}
\hline \multirow[b]{3}{*}{ Variables } & \multicolumn{4}{|c|}{ Female } & \multicolumn{4}{|c|}{ Male } \\
\hline & \multicolumn{2}{|c|}{ Specification I } & \multicolumn{2}{|c|}{ Specification II } & \multicolumn{2}{|c|}{ Specification I } & \multicolumn{2}{|c|}{ Specification II } \\
\hline & $\begin{array}{l}\text { Resident } \\
\text { care }\end{array}$ & $\begin{array}{c}\text { Non- } \\
\text { resident care }\end{array}$ & $\begin{array}{l}\text { Resident } \\
\text { care }\end{array}$ & $\begin{array}{c}\text { Non- } \\
\text { resident care }\end{array}$ & $\begin{array}{l}\text { Resident } \\
\text { care }\end{array}$ & $\begin{array}{c}\text { Non- } \\
\text { resident care }\end{array}$ & $\begin{array}{l}\text { Resident } \\
\text { care }\end{array}$ & $\begin{array}{c}\text { Non- } \\
\text { resident care }\end{array}$ \\
\hline \multirow[t]{2}{*}{ Resident care last year ${ }^{(a)}$} & $1.96^{* * *}$ & 0.58 & $1.94 * * *$ & 0.48 & $1.42 * * *$ & -0.12 & $1.46^{* * *}$ & 0.11 \\
\hline & $(0.23)$ & $(0.39)$ & $(0.23)$ & $(0.42)$ & $(0.30)$ & $(0.60)$ & $(0.30)$ & $(0.63)$ \\
\hline \multirow[t]{2}{*}{ Non-resident care last year ${ }^{(a)}$} & 0.35 & $1.23 * * *$ & 0.24 & $1.23 * * *$ & 0.18 & $1.38 * * *$ & 0.47 & $1.31 * * *$ \\
\hline & $(0.43)$ & $(0.17)$ & $(0.45)$ & $(0.17)$ & $(0.65)$ & $(0.26)$ & $(0.68)$ & $(0.26)$ \\
\hline \multirow[t]{2}{*}{ Resident care at $\mathrm{t}=1^{\text {(a) }}$} & $4.62 * * *$ & -0.02 & $4.65 * * *$ & 0.11 & $5.90 * * *$ & $1.60 * * *$ & $5.82 * * *$ & $1.41 * *$ \\
\hline & $(0.54)$ & $(0.46)$ & $(0.54)$ & $(0.51)$ & $(0.70)$ & $(0.54)$ & $(0.69)$ & $(0.55)$ \\
\hline \multirow[t]{2}{*}{ Non-resident care at $\mathrm{t}=1^{\text {(a) }}$} & 0.19 & $2.69 * * *$ & 0.24 & $2.67 * * *$ & $2.37 * * *$ & $2.39 * * *$ & $2.30 * * *$ & $2.44 * * *$ \\
\hline & $(0.59)$ & $(0.30)$ & $(0.58)$ & $(0.30)$ & $(0.68)$ & $(0.41)$ & $(0.67)$ & $(0.40)$ \\
\hline \multirow[t]{2}{*}{ Overall work satisfaction last year } & -0.07 & 0.01 & -0.07 & 0.01 & -0.02 & 0.01 & -0.02 & 0.02 \\
\hline & $(0.07)$ & $(0.05)$ & $(0.07)$ & $(0.05)$ & $(0.08)$ & $(0.07)$ & $(0.08)$ & $(0.07)$ \\
\hline \multirow[t]{2}{*}{ Unemployed last year } & 0.37 & 0.28 & 0.38 & 0.28 & $0.72 *$ & -0.33 & $0.72 *$ & -0.33 \\
\hline & $(0.25)$ & $(0.19)$ & $(0.25)$ & $(0.19)$ & $(0.41)$ & $(0.36)$ & $(0.41)$ & $(0.35)$ \\
\hline \multirow[t]{2}{*}{ Overall work satisfaction at $\mathrm{t}=1$} & 0.04 & -0.04 & 0.05 & -0.03 & -0.04 & -0.04 & -0.03 & -0.04 \\
\hline & $(0.11)$ & $(0.06)$ & $(0.11)$ & $(0.06)$ & $(0.11)$ & $(0.07)$ & $(0.11)$ & $(0.07)$ \\
\hline \multirow[t]{2}{*}{ Unemployed at $\mathrm{t}=1$} & 0.34 & -0.07 & 0.32 & -0.06 & 0.85 & 0.40 & 0.83 & 0.40 \\
\hline & $(0.32)$ & $(0.23)$ & $(0.32)$ & $(0.23)$ & $(0.56)$ & $(0.43)$ & $(0.55)$ & $(0.42)$ \\
\hline
\end{tabular}

Notes: Coefficient estimates from MSL estimation with 50 Halton draws; ${ }^{(a)}$ indicates non-carer as the base group. Standard errors in parentheses; ${ }^{* * *} \mathrm{p}<0.01,{ }^{* *} \mathrm{p}<0.05,{ }^{*} \mathrm{p}<0.1$. Estimates on other variables are omitted. 
Appendix Table A9: Caregiving intensity dynamics: Main versus secondary care - Model 1 with employment status (Remaining results)

\begin{tabular}{|c|c|c|c|c|c|c|c|c|}
\hline \multirow[b]{3}{*}{ Variables } & \multicolumn{4}{|c|}{ Female } & \multicolumn{4}{|c|}{ Male } \\
\hline & \multicolumn{2}{|c|}{ Specification I } & \multicolumn{2}{|c|}{ Specification II } & \multicolumn{2}{|c|}{ Specification I } & \multicolumn{2}{|c|}{ Specification II } \\
\hline & Main & $\begin{array}{c}\text { Secondar } \\
\text { y }\end{array}$ & Main & $\begin{array}{c}\text { Secondar } \\
\mathrm{y}\end{array}$ & Main & $\begin{array}{c}\text { Secondar } \\
\text { y }\end{array}$ & Main & $\begin{array}{c}\text { Secondar } \\
\mathrm{y}\end{array}$ \\
\hline Main care last year ${ }^{(a)}$ & $\begin{array}{l}1.84 * * * \\
(0.18)\end{array}$ & $\begin{array}{l}1.52^{* * *} \\
(0.21)\end{array}$ & $\begin{array}{l}1.54^{* * *} \\
(0.18)\end{array}$ & $\begin{array}{l}0.81^{* * *} \\
(0.23)\end{array}$ & $\begin{array}{l}2.02^{* * *} \\
(0.31)\end{array}$ & $\begin{array}{l}0.95^{* *} \\
(0.39)\end{array}$ & $\begin{array}{l}1.84^{* * *} \\
(0.32)\end{array}$ & $\begin{array}{l}0.42 \\
(0.39)\end{array}$ \\
\hline Secondary care last year (a) & $\begin{array}{l}1.95^{* * *} \\
(0.22)\end{array}$ & $\begin{array}{l}1.61^{* * *} \\
(0.19)\end{array}$ & $\begin{array}{l}1.26^{* * * *} \\
(0.24)\end{array}$ & $\begin{array}{l}1.55^{* * *} \\
(0.19)\end{array}$ & $\begin{array}{l}1.54^{* * *} \\
(0.35)\end{array}$ & $\begin{array}{l}1.58^{* * * *} \\
(0.24)\end{array}$ & $\begin{array}{l}0.79 * * \\
(0.39)\end{array}$ & $\begin{array}{l}1.50 * * * \\
(0.24)\end{array}$ \\
\hline Main care at $\mathrm{t}=1^{\text {(a) }}$ & $\begin{array}{l}3.23^{* * *} \\
(0.33)\end{array}$ & $\begin{array}{l}1.04 * * * \\
(0.27)\end{array}$ & $\begin{array}{l}3.72 * * * \\
(0.37)\end{array}$ & $\begin{array}{l}1.92 * * * \\
(0.31)\end{array}$ & $\begin{array}{l}3.64 * * * \\
(0.55)\end{array}$ & $\begin{array}{l}1.78^{* * *} \\
(0.44)\end{array}$ & $\begin{array}{l}3.95 * * * \\
(0.58)\end{array}$ & $\begin{array}{l}2.35^{* * *} \\
(0.49)\end{array}$ \\
\hline Secondary care at $\mathrm{t}=1^{\text {(a) }}$ & $\begin{array}{l}1.36 * * * \\
(0.35)\end{array}$ & $\begin{array}{l}2.23^{* * *} \\
(0.29)\end{array}$ & $\begin{array}{l}2.06^{* * *} \\
(0.43)\end{array}$ & $\begin{array}{l}2.45^{* * *} \\
(0.29)\end{array}$ & $\begin{array}{l}0.98^{* *} \\
(0.49)\end{array}$ & $\begin{array}{l}2.67 * * * \\
(0.36)\end{array}$ & $\begin{array}{l}1.58^{* * *} \\
(0.54)\end{array}$ & $\begin{array}{l}2.84 * * * \\
(0.37)\end{array}$ \\
\hline Work full timelast year ${ }^{(\mathrm{D})}$ & $\begin{array}{l}-0.77 * * * \\
(0.26)\end{array}$ & $\begin{array}{l}-0.43^{*} \\
(0.23)\end{array}$ & $\begin{array}{l}-0.85^{* * *} \\
(0.27)\end{array}$ & $\begin{array}{l}-0.47^{* *} \\
(0.23)\end{array}$ & $\begin{array}{l}-1.21^{* * *} \\
(0.36)\end{array}$ & $\begin{array}{l}0.29 \\
(0.35)\end{array}$ & $\begin{array}{l}-1.23^{* * *} \\
(0.36)\end{array}$ & $\begin{array}{l}0.23 \\
(0.35)\end{array}$ \\
\hline Work part time last year ${ }^{(\mathrm{b})}$ & $\begin{array}{l}-0.01 \\
(0.21)\end{array}$ & $\begin{array}{l}-0.30 \\
(0.20)\end{array}$ & $\begin{array}{l}-0.09 \\
(0.21)\end{array}$ & $\begin{array}{l}-0.26 \\
(0.20)\end{array}$ & $\begin{array}{l}-1.09 * * \\
(0.47)\end{array}$ & $\begin{array}{l}0.85 * * \\
(0.38)\end{array}$ & $\begin{array}{l}-1.13^{* *} \\
(0.47)\end{array}$ & $\begin{array}{l}0.80 * * \\
(0.38)\end{array}$ \\
\hline Self-employed last year ${ }^{(0)}$ & $\begin{array}{l}0.05 \\
(0.36)\end{array}$ & $\begin{array}{l}-0.48 \\
(0.38)\end{array}$ & $\begin{array}{l}-0.03 \\
(0.37)\end{array}$ & $\begin{array}{l}-0.40 \\
(0.37)\end{array}$ & $\begin{array}{l}-1.73^{* * *} \\
(0.49)\end{array}$ & $\begin{array}{l}0.68 \\
(0.44)\end{array}$ & $\begin{array}{l}-1.65^{* * *} \\
(0.49)\end{array}$ & $\begin{array}{l}0.57 \\
(0.44)\end{array}$ \\
\hline Work full timeat $\mathrm{t}=1^{(\mathrm{D})}$ & $\begin{array}{l}0.01 \\
(0.29)\end{array}$ & $\begin{array}{l}0.20 \\
(0.26)\end{array}$ & $\begin{array}{l}-0.07 \\
(0.31)\end{array}$ & $\begin{array}{l}0.09 \\
(0.26)\end{array}$ & $\begin{array}{l}-0.28 \\
(0.46)\end{array}$ & $\begin{array}{l}-0.03 \\
(0.39)\end{array}$ & $\begin{array}{l}-0.32 \\
(0.46)\end{array}$ & $\begin{array}{l}-0.10 \\
(0.40)\end{array}$ \\
\hline Work part time at $\mathrm{t}=1^{(\mathrm{b})}$ & $\begin{array}{l}-0.44 * \\
(0.26)\end{array}$ & $\begin{array}{l}0.24 \\
(0.22)\end{array}$ & $\begin{array}{l}-0.48^{*} \\
(0.28)\end{array}$ & $\begin{array}{l}0.10 \\
(0.23)\end{array}$ & $\begin{array}{l}-0.27 \\
(0.60)\end{array}$ & $\begin{array}{l}-1.62 * * \\
(0.68)\end{array}$ & $\begin{array}{l}-0.27 \\
(0.60)\end{array}$ & $\begin{array}{l}-1.74^{* *} \\
(0.68)\end{array}$ \\
\hline Self-employed at $\mathrm{t}=1^{(\mathrm{D})}$ & $\begin{array}{l}-0.33 \\
(0.43)\end{array}$ & $\begin{array}{l}-0.24 \\
(0.40)\end{array}$ & $\begin{array}{l}-0.35 \\
(0.45)\end{array}$ & $\begin{array}{l}-0.29 \\
(0.39)\end{array}$ & $\begin{array}{l}-0.15 \\
(0.56)\end{array}$ & $\begin{array}{l}-0.95 * \\
(0.51)\end{array}$ & $\begin{array}{l}-0.26 \\
(0.57)\end{array}$ & $\begin{array}{l}-1.02^{* *} \\
(0.51)\end{array}$ \\
\hline Age & $\begin{array}{l}-0.19 \\
(0.27)\end{array}$ & $\begin{array}{l}0.05 \\
(0.26)\end{array}$ & $\begin{array}{l}-0.18 \\
(0.27)\end{array}$ & $\begin{array}{l}0.08 \\
(0.26)\end{array}$ & $\begin{array}{l}0.17 \\
(0.40)\end{array}$ & $\begin{array}{l}-0.44 \\
(0.31)\end{array}$ & $\begin{array}{l}0.08 \\
(0.40)\end{array}$ & $\begin{array}{l}-0.42 \\
(0.31)\end{array}$ \\
\hline Age squared & $\begin{array}{l}-0.00 \\
(0.00)\end{array}$ & $\begin{array}{l}-0.00 * * \\
(0.00)\end{array}$ & $\begin{array}{l}-0.00 \\
(0.00)\end{array}$ & $\begin{array}{l}-0.00 * * \\
(0.00)\end{array}$ & $\begin{array}{l}-0.00 \\
(0.00)\end{array}$ & $\begin{array}{l}0.00 \\
(0.00)\end{array}$ & $\begin{array}{l}0.00 \\
(0.00)\end{array}$ & $\begin{array}{l}0.00 \\
(0.00)\end{array}$ \\
\hline ESB immigrant ${ }^{(c)}$ & $\begin{array}{l}-0.44 \\
(0.38)\end{array}$ & $\begin{array}{l}-0.18 \\
(0.29)\end{array}$ & $\begin{array}{l}-0.65 \\
(0.42)\end{array}$ & $\begin{array}{l}-0.31 \\
(0.30)\end{array}$ & $\begin{array}{l}0.19 \\
(0.41)\end{array}$ & $\begin{array}{l}0.36 \\
(0.30)\end{array}$ & $\begin{array}{l}0.26 \\
(0.42)\end{array}$ & $\begin{array}{l}0.42 \\
(0.30)\end{array}$ \\
\hline NESB immigrant (northwest Europe) ${ }^{(\mathrm{c})}$ & $\begin{array}{l}0.45 \\
(0.57)\end{array}$ & $\begin{array}{l}-0.51 \\
(0.58)\end{array}$ & $\begin{array}{l}0.33 \\
(0.62)\end{array}$ & $\begin{array}{l}-0.31 \\
(0.53)\end{array}$ & $\begin{array}{l}1.21 \\
(0.76)\end{array}$ & $\begin{array}{l}-0.24 \\
(0.89)\end{array}$ & $\begin{array}{l}1.04 \\
(0.81)\end{array}$ & $\begin{array}{l}-0.10 \\
(0.89)\end{array}$ \\
\hline NESB immigrant (other) ${ }^{(\mathrm{c})}$ & $\begin{array}{l}0.32 \\
(0.39)\end{array}$ & $\begin{array}{l}0.23 \\
(0.33)\end{array}$ & $\begin{array}{l}0.25 \\
(0.43)\end{array}$ & $\begin{array}{l}0.24 \\
(0.33)\end{array}$ & $\begin{array}{l}0.74 \\
(0.52)\end{array}$ & $\begin{array}{l}0.92 * * \\
(0.37)\end{array}$ & $\begin{array}{l}0.72 \\
(0.53)\end{array}$ & $\begin{array}{l}0.86 * * \\
(0.38)\end{array}$ \\
\hline Child immigrant & $\begin{array}{l}0.84 * * \\
(0.42)\end{array}$ & $\begin{array}{l}0.79 * * \\
(0.36)\end{array}$ & $\begin{array}{l}0.86^{*} \\
(0.46)\end{array}$ & $\begin{array}{l}0.79 * * \\
(0.36)\end{array}$ & $\begin{array}{l}0.88^{*} \\
(0.53)\end{array}$ & $\begin{array}{l}1.27^{* * * *} \\
(0.40)\end{array}$ & $\begin{array}{l}0.90^{*} \\
(0.53)\end{array}$ & $\begin{array}{l}1.21^{* * *} \\
(0.39)\end{array}$ \\
\hline Year $12^{(\mathrm{d})}$ & $\begin{array}{l}-0.20 \\
(0.29)\end{array}$ & $\begin{array}{l}0.18 \\
(0.25)\end{array}$ & $\begin{array}{l}-0.13 \\
(0.32)\end{array}$ & $\begin{array}{l}0.15 \\
(0.26)\end{array}$ & $\begin{array}{l}0.03 \\
(0.43)\end{array}$ & $\begin{array}{l}-0.49 \\
(0.37)\end{array}$ & $\begin{array}{l}0.08 \\
(0.44)\end{array}$ & $\begin{array}{l}-0.48 \\
(0.36)\end{array}$ \\
\hline Vocational training $^{(\mathrm{d})}$ & $\begin{array}{l}-0.12 \\
(0.20)\end{array}$ & $\begin{array}{l}0.49 * * * \\
(0.18)\end{array}$ & $\begin{array}{l}-0.13 \\
(0.22)\end{array}$ & $\begin{array}{l}0.54^{* * * *} \\
(0.18)\end{array}$ & $\begin{array}{l}-0.08 \\
(0.28)\end{array}$ & $\begin{array}{l}0.02 \\
(0.22)\end{array}$ & $\begin{array}{l}-0.04 \\
(0.29)\end{array}$ & $\begin{array}{l}0.00 \\
(0.23)\end{array}$ \\
\hline Bachelor or higher ${ }^{(a)}$ & $\begin{array}{l}-0.50 * \\
(0.28)\end{array}$ & $\begin{array}{l}0.37 * \\
(0.22)\end{array}$ & $\begin{array}{l}-0.50 * \\
(0.30)\end{array}$ & $\begin{array}{l}0.33 \\
(0.23)\end{array}$ & $\begin{array}{l}-0.37 \\
(0.40)\end{array}$ & $\begin{array}{l}-0.16 \\
(0.28)\end{array}$ & $\begin{array}{l}-0.35 \\
(0.40)\end{array}$ & $\begin{array}{l}-0.28 \\
(0.29)\end{array}$ \\
\hline Married/de facto ${ }^{(e)}$ & $\begin{array}{l}-1.03 \\
(0.79)\end{array}$ & $\begin{array}{l}-0.39 \\
(0.77)\end{array}$ & $\begin{array}{l}-1.10 \\
(0.80)\end{array}$ & $\begin{array}{l}-0.44 \\
(0.77)\end{array}$ & $\begin{array}{l}1.36 \\
(1.01)\end{array}$ & $\begin{array}{l}-0.88 \\
(0.94)\end{array}$ & $\begin{array}{l}1.37 \\
(0.99)\end{array}$ & $\begin{array}{l}-0.88 \\
(0.94)\end{array}$ \\
\hline Separated/divorced/widowed ${ }^{(\mathrm{e})}$ & $\begin{array}{l}-0.68 \\
(0.87)\end{array}$ & $\begin{array}{l}-0.39 \\
(0.77)\end{array}$ & $\begin{array}{l}-0.70 \\
(0.88)\end{array}$ & $\begin{array}{l}-0.44 \\
(0.77)\end{array}$ & 0.02 & -0.88 & 0.03 & -0.88 \\
\hline Disable & $\begin{array}{l}0.33^{*} \\
(0.19)\end{array}$ & $\begin{array}{l}0.25 \\
(0.19)\end{array}$ & $\begin{array}{l}(0.08) \\
0.32 * \\
(0.19)\end{array}$ & $\begin{array}{l}0.28 \\
(0.19)\end{array}$ & $\begin{array}{l}(1.22) \\
0.15 \\
(0.28)\end{array}$ & $\begin{array}{l}(0.04) \\
-0.07 \\
(0.24)\end{array}$ & $\begin{array}{l}(1.20) \\
0.16 \\
(0.28)\end{array}$ & $\begin{array}{l}-0.07 \\
(0.24)\end{array}$ \\
\hline Non-wage household income & $\begin{array}{l}0.32 \\
(0.38)\end{array}$ & $\begin{array}{l}-0.42 \\
(0.31)\end{array}$ & $\begin{array}{l}0.31 \\
(0.38)\end{array}$ & $\begin{array}{l}-0.39 \\
(0.30)\end{array}$ & $\begin{array}{l}-0.64 \\
(0.77)\end{array}$ & $\begin{array}{l}1.06 \\
(0.65)\end{array}$ & $\begin{array}{l}-0.61 \\
(0.77)\end{array}$ & $\begin{array}{l}1.07^{*} \\
(0.65)\end{array}$ \\
\hline Home owner with mortgage ${ }^{(\mathrm{t})}$ & $\begin{array}{l}0.89 * * \\
(0.36)\end{array}$ & $\begin{array}{l}0.13 \\
(0.35)\end{array}$ & $\begin{array}{l}0.92 * * \\
(0.37)\end{array}$ & $\begin{array}{l}0.23 \\
(0.35)\end{array}$ & $\begin{array}{l}-0.43 \\
(0.47)\end{array}$ & $\begin{array}{l}-0.30 \\
(0.37)\end{array}$ & $\begin{array}{l}-0.32 \\
(0.48)\end{array}$ & $\begin{array}{l}-0.32 \\
(0.38)\end{array}$ \\
\hline Home owner without mortgage ${ }^{(t)}$ & $\begin{array}{l}0.67^{*} \\
(0.38)\end{array}$ & $\begin{array}{l}-0.00 \\
(0.39)\end{array}$ & $\begin{array}{l}0.69 * \\
(0.39)\end{array}$ & $\begin{array}{l}0.09 \\
(0.38)\end{array}$ & $\begin{array}{l}-0.98^{*} \\
(0.51)\end{array}$ & $\begin{array}{l}-0.05 \\
(0.41)\end{array}$ & $\begin{array}{l}-0.87^{*} \\
(0.51)\end{array}$ & $\begin{array}{l}-0.10 \\
(0.41)\end{array}$ \\
\hline Number of persons aged $0-4$ & $\begin{array}{l}0.02 \\
(0.26)\end{array}$ & $\begin{array}{l}-0.47 \\
(0.29)\end{array}$ & $\begin{array}{l}-0.03 \\
(0.27)\end{array}$ & $\begin{array}{l}-0.43 \\
(0.29)\end{array}$ & $\begin{array}{l}0.13 \\
(0.37)\end{array}$ & $\begin{array}{l}-0.22 \\
(0.28)\end{array}$ & $\begin{array}{l}0.11 \\
(0.37)\end{array}$ & $\begin{array}{l}-0.23 \\
(0.28)\end{array}$ \\
\hline Number of persons aged 5-9 & $\begin{array}{l}0.04 \\
(0.22)\end{array}$ & $\begin{array}{l}-0.24 \\
(0.24)\end{array}$ & $\begin{array}{l}0.01 \\
(0.23)\end{array}$ & $\begin{array}{l}-0.20 \\
(0.24)\end{array}$ & $\begin{array}{l}0.18 \\
(0.34)\end{array}$ & $\begin{array}{l}0.26 \\
(0.26)\end{array}$ & $\begin{array}{l}0.19 \\
(0.35)\end{array}$ & $\begin{array}{l}0.26 \\
(0.26)\end{array}$ \\
\hline Number of persons aged 10-14 & $\begin{array}{l}0.00 \\
(0.19)\end{array}$ & $\begin{array}{l}0.07 \\
(0.20)\end{array}$ & $\begin{array}{l}0.04 \\
(0.19)\end{array}$ & $\begin{array}{l}0.09 \\
(0.19)\end{array}$ & $\begin{array}{l}0.40 \\
(0.30)\end{array}$ & $\begin{array}{l}0.06 \\
(0.22)\end{array}$ & $\begin{array}{l}0.40 \\
(0.29)\end{array}$ & $\begin{array}{l}0.06 \\
(0.22)\end{array}$ \\
\hline Number of persons aged 15-23 & -0.05 & 0.14 & -0.04 & 0.14 & 0.20 & -0.05 & 0.20 & -0.06 \\
\hline
\end{tabular}




\begin{tabular}{|c|c|c|c|c|c|c|c|c|}
\hline \multirow[b]{3}{*}{ Variables } & \multicolumn{4}{|c|}{ Female } & \multicolumn{4}{|c|}{ Male } \\
\hline & \multicolumn{2}{|c|}{ Specification I } & \multicolumn{2}{|c|}{ Specification II } & \multicolumn{2}{|c|}{ Specification I } & \multicolumn{2}{|c|}{ Specification II } \\
\hline & Main & $\begin{array}{c}\text { Secondar } \\
\mathrm{y}\end{array}$ & Main & $\begin{array}{c}\text { Secondar } \\
\text { y }\end{array}$ & Main & $\begin{array}{c}\text { Secondar } \\
\mathrm{y}\end{array}$ & Main & $\begin{array}{c}\text { Secondar } \\
\mathrm{y}\end{array}$ \\
\hline & $(0.16)$ & $(0.16)$ & $(0.16)$ & $(0.15)$ & $(0.26)$ & $(0.19)$ & $(0.25)$ & $(0.20)$ \\
\hline Number of persons aged 24-63 & $0.42 *$ & $0.46^{*}$ & $0.46 *$ & $0.49 *$ & 0.48 & 0.33 & 0.51 & 0.34 \\
\hline & $(0.25)$ & $(0.26)$ & $(0.26)$ & $(0.26)$ & $(0.43)$ & $(0.32)$ & $(0.43)$ & $(0.32)$ \\
\hline Number of elderly & $\begin{array}{l}1.54 * * * \\
(0.36)\end{array}$ & $\begin{array}{l}0.46 * \\
(0.26)\end{array}$ & $\begin{array}{l}1.56 * * * \\
(0.36)\end{array}$ & $\begin{array}{l}0.49 * \\
(0.26)\end{array}$ & $\begin{array}{l}1.72 * * * \\
(0.57)\end{array}$ & $\begin{array}{l}0.33 \\
(0.32)\end{array}$ & $\begin{array}{l}1.78 * * * \\
(0.57)\end{array}$ & $\begin{array}{l}0.34 \\
(0.32)\end{array}$ \\
\hline Death of close relative & $\begin{array}{l}-0.43^{* *} \\
(0.18)\end{array}$ & $\begin{array}{l}-0.61^{* * *} \\
(0.18)\end{array}$ & $\begin{array}{l}-0.46^{* *} \\
(0.19)\end{array}$ & $\begin{array}{l}-0.59^{* * *} \\
(0.18)\end{array}$ & $\begin{array}{l}-0.38 \\
(0.29)\end{array}$ & $\begin{array}{l}-0.47^{* *} \\
(0.23)\end{array}$ & $\begin{array}{l}-0.42 \\
(0.29)\end{array}$ & $\begin{array}{l}-0.47 * * \\
(0.23)\end{array}$ \\
\hline Death of close friend & $\begin{array}{l}0.15 \\
(0.20)\end{array}$ & $\begin{array}{l}0.09 \\
(0.20)\end{array}$ & $\begin{array}{l}0.14 \\
(0.20)\end{array}$ & $\begin{array}{l}0.10 \\
(0.20)\end{array}$ & $\begin{array}{l}0.08 \\
(0.30)\end{array}$ & $\begin{array}{l}0.08 \\
(0.24)\end{array}$ & $\begin{array}{l}0.13 \\
(0.30)\end{array}$ & $\begin{array}{l}0.08 \\
(0.24)\end{array}$ \\
\hline Injury to self & $\begin{array}{l}-0.03 \\
(0.22)\end{array}$ & $\begin{array}{l}-0.29 \\
(0.24)\end{array}$ & $\begin{array}{l}-0.05 \\
(0.22)\end{array}$ & $\begin{array}{l}-0.29 \\
(0.24)\end{array}$ & $\begin{array}{l}-0.55 \\
(0.39)\end{array}$ & $\begin{array}{l}-0.39 \\
(0.29)\end{array}$ & $\begin{array}{l}-0.57 \\
(0.38)\end{array}$ & $\begin{array}{l}-0.40 \\
(0.29)\end{array}$ \\
\hline Injury/illness of relative/family member & $\begin{array}{l}0.52^{* * *} \\
(0.15)\end{array}$ & $\begin{array}{l}0.38^{* * *} \\
(0.15)\end{array}$ & $\begin{array}{l}0.53^{* * * *} \\
(0.15)\end{array}$ & $\begin{array}{l}0.41^{* * * *} \\
(0.15)\end{array}$ & $\begin{array}{l}0.59 * * \\
(0.24)\end{array}$ & $\begin{array}{l}0.73^{* * *} \\
(0.19)\end{array}$ & $\begin{array}{l}0.64 * * * \\
(0.24)\end{array}$ & $\begin{array}{l}0.76^{* * *} \\
(0.19)\end{array}$ \\
\hline
\end{tabular}

Notes: Coefficient estimates from MSL estimation with 50 Halton draws. Sample size: 12,348 person-y ears (2,058 persons)

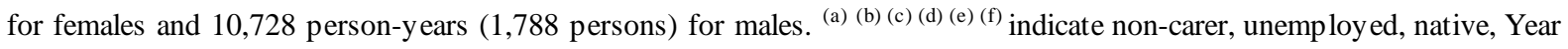
11 or under, never married, and renter as the base group, respectively. Standard errors are in parentheses. $* * * \mathrm{p}<0.01, * *$ $\mathrm{p}<0.05{ }^{*} \mathrm{p}<0.1$. Estimates on the year dummies, state dummies, local variables and the initial conditions are omitted. 
Appendix Table A10: Caregiving intensity dynamics: Main versus secondary care - Model 2 with work security and flexibility indicators (Coefficient estimates)

\begin{tabular}{|c|c|c|c|c|c|c|c|c|}
\hline \multirow[b]{3}{*}{ Variables } & \multicolumn{4}{|c|}{ Female } & \multicolumn{4}{|c|}{ Male } \\
\hline & \multicolumn{2}{|c|}{ Specification I } & \multicolumn{2}{|c|}{ Specification II } & \multicolumn{2}{|c|}{ Specification I } & \multicolumn{2}{|c|}{ Specification II } \\
\hline & Main & Secondary & Main & Secondary & Main & Secondary & Main & Secondary \\
\hline \multirow[t]{2}{*}{ Main care last year ${ }^{(a)}$} & $1.86^{* * *}$ & $1.46^{* * *}$ & $1.52^{* * *}$ & $0.76^{* * *}$ & $2.02 * * *$ & $1.08 * * *$ & $1.76^{* * *}$ & 0.44 \\
\hline & $(0.19)$ & $(0.22)$ & $(0.19)$ & $(0.23)$ & $(0.32)$ & $(0.40)$ & $(0.32)$ & $(0.40)$ \\
\hline \multirow[t]{2}{*}{ Secondary care last year ${ }^{(a)}$} & $1.81 * * *$ & $1.57 * * *$ & $1.23^{* * *}$ & $1.41^{* * *}$ & $1.56^{* * *}$ & $1.61^{* * *}$ & $0.85 * *$ & $1.46^{* * *}$ \\
\hline & $\begin{array}{l}(0.23) \\
3.17 * * *\end{array}$ & $\begin{array}{l}(0.19) \\
1.14^{* * *}\end{array}$ & $\begin{array}{l}(0.24) \\
3.78^{* * *}\end{array}$ & $\begin{array}{l}(0.19) \\
1.93 * * *\end{array}$ & $\begin{array}{l}(0.37) \\
3.74 * * *\end{array}$ & $\begin{array}{l}(0.25) \\
1.70 * * *\end{array}$ & $\begin{array}{l}(0.37) \\
4.22^{* * *}\end{array}$ & $\begin{array}{l}(0.24) \\
2.52 * * *\end{array}$ \\
\hline Main care at $\mathrm{t}=1^{\text {(a) }}$ & $(0.35)$ & $(0.28)$ & $(0.38)$ & $(0.32)$ & $(0.55)$ & $(0.49)$ & $(0.59)$ & $(0.51)$ \\
\hline \multirow[t]{2}{*}{ Secondary care at $\mathrm{t}=1^{\text {(a) }}$} & $1.34 * * *$ & $2.29 * * *$ & $2.15^{* * *}$ & $2.61 * * *$ & $0.99 * *$ & $2.78 * * *$ & $1.72 * * *$ & $3.06 * * *$ \\
\hline & $(0.42)$ & $(0.29)$ & $(0.42)$ & $(0.31)$ & $(0.49)$ & $(0.37)$ & $(0.52)$ & $(0.38)$ \\
\hline \multirow[t]{2}{*}{ Job security index last year } & $-0.10^{* *}$ & 0.03 & $-0.10^{* *}$ & 0.03 & 0.08 & 0.05 & 0.10 & 0.05 \\
\hline & $(0.04)$ & $(0.04)$ & $(0.04)$ & $(0.04)$ & $(0.07)$ & $(0.05)$ & $(0.07)$ & $(0.05)$ \\
\hline \multirow[t]{2}{*}{ Work and life job satisfaction last year } & 0.06 & -0.01 & 0.07 & -0.01 & -0.02 & 0.01 & -0.02 & 0.01 \\
\hline & $(0.05)$ & $(0.04)$ & $(0.05)$ & $(0.04)$ & $(0.06)$ & $(0.05)$ & $(0.06)$ & $(0.05)$ \\
\hline \multirow[t]{2}{*}{ Unemployed last year } & 0.30 & 0.31 & $0.34^{*}$ & $0.33^{*}$ & $1.11^{* * *}$ & $-0.75^{* *}$ & $1.04 * * *$ & $-0.71^{* *}$ \\
\hline & $(0.20)$ & $(0.20)$ & $(0.21)$ & $(0.20)$ & $(0.35)$ & $(0.35)$ & $(0.36)$ & $(0.35)$ \\
\hline \multirow[t]{2}{*}{ Job security index at $t=1$} & 0.04 & -0.04 & 0.04 & -0.03 & $-0.12 *$ & $-0.10 *$ & $-0.12 *$ & $-0.09 *$ \\
\hline & $(0.06)$ & $(0.04)$ & $(0.06)$ & $(0.05)$ & $(0.07)$ & $(0.05)$ & $(0.07)$ & $(0.05)$ \\
\hline \multirow[t]{2}{*}{ Work and life job satisfaction at $\mathrm{t}=1$} & -0.07 & -0.01 & -0.01 & -0.00 & 0.03 & -0.02 & 0.04 & -0.02 \\
\hline & $(0.06)$ & $(0.05)$ & $(0.06)$ & $(0.05)$ & $(0.07)$ & $(0.05)$ & $(0.07)$ & $(0.05)$ \\
\hline \multirow{2}{*}{ Unemployed at $\mathrm{t}=1$} & 0.19 & -0.18 & 0.19 & -0.18 & 0.55 & 0.44 & 0.69 & 0.59 \\
\hline & $(0.23)$ & $(0.22)$ & $(0.26)$ & $(0.23)$ & $(0.44)$ & $(0.40)$ & $(0.46)$ & $(0.41)$ \\
\hline
\end{tabular}

Notes: Coefficient estimates from MSL estimation with 50 Halton draws; ${ }^{(a)}$ indicates non-carer as the base group. Standard errors in parentheses; ${ }^{* * *} \mathrm{p}<0.01,{ }^{* *} \mathrm{p}<0.05,{ }^{*} \mathrm{p}<0.1$. Estimates on other variables are omitted. 
Appendix Table A11: Caregiving intensity dynamics: Main versus secondary care - Model 3 with overall work satisfaction indicator (Coefficient estimates)

\begin{tabular}{|c|c|c|c|c|c|c|c|c|}
\hline \multirow[b]{3}{*}{ Variables } & \multicolumn{4}{|c|}{ Female } & \multicolumn{4}{|c|}{ Male } \\
\hline & \multicolumn{2}{|c|}{ Specification I } & \multicolumn{2}{|c|}{ Specification II } & \multicolumn{2}{|c|}{ Specification I } & \multicolumn{2}{|c|}{ Specification II } \\
\hline & Main & Secondary & Main & Secondary & Main & Secondary & Main & Secondary \\
\hline Main care last year ${ }^{(a)}$ & $1.89 * * *$ & $1.47^{* * *}$ & $1.56^{* * *}$ & $0.79^{* * *}$ & $1.98^{* * *}$ & $1.09^{* * *}$ & $1.73^{* * *}$ & 0.45 \\
\hline & (0.19) & $(0.22)$ & $(0.19)$ & $(0.23)$ & $(0.32)$ & $(0.40)$ & $(0.31)$ & $(0.40)$ \\
\hline Secondary care last year ${ }^{(a)}$ & $1.83^{* * *}$ & $1.58^{* * *}$ & $1.24 * * *$ & $1.41^{* * *}$ & $1.56^{* * *}$ & $1.62^{* * *}$ & $0.84 * *$ & $1.46^{* * *}$ \\
\hline & $(0.23)$ & $(0.19)$ & $(0.24)$ & $(0.19)$ & $(0.37)$ & $(0.25)$ & $(0.38)$ & $(0.24)$ \\
\hline Main care at $\mathrm{t}=1^{(\mathrm{a})}$ & $3.12^{* * *}$ & $1.14^{* * *}$ & $3.69 * * *$ & $1.91^{* * *}$ & $3.83^{* * *}$ & $1.70^{* * *}$ & $4.27^{* * *}$ & $2.53^{* * *}$ \\
\hline & $(0.34)$ & $(0.28)$ & $(0.38)$ & $(0.32)$ & $(0.56)$ & $(0.47)$ & $(0.60)$ & $(0.52)$ \\
\hline Secondary care at $\mathrm{t}=1^{(\mathrm{a})}$ & $1.29 * * *$ & $2.27^{* * *}$ & $2.13^{* * *}$ & $2.59^{* * *}$ & $1.02^{* *}$ & $2.77^{* * *}$ & $1.74^{* * *}$ & $3.06^{* * *}$ \\
\hline & $(0.45)$ & $(0.29)$ & $(0.43)$ & $(0.31)$ & $(0.50)$ & $(0.37)$ & $(0.53)$ & $(0.39)$ \\
\hline Overall work satisfaction last year & $\begin{array}{l}-0.02 \\
(0.06)\end{array}$ & $\begin{array}{l}-0.03 \\
(0.05)\end{array}$ & $\begin{array}{l}-0.01 \\
(0.06)\end{array}$ & $\begin{array}{l}-0.03 \\
(0.05)\end{array}$ & $\begin{array}{l}0.07 \\
(0.08)\end{array}$ & $\begin{array}{l}-0.03 \\
(0.06)\end{array}$ & $\begin{array}{l}0.07 \\
(0.08)\end{array}$ & $\begin{array}{l}-0.02 \\
(0.06)\end{array}$ \\
\hline Unemployed last year & $\begin{array}{l}0.25 \\
(0.20)\end{array}$ & $\begin{array}{l}0.33^{*} \\
(0.20)\end{array}$ & $\begin{array}{l}0.27 \\
(0.20)\end{array}$ & $\begin{array}{l}0.36^{*} \\
(0.20)\end{array}$ & $\begin{array}{l}1.19 * * * \\
(0.35)\end{array}$ & $\begin{array}{l}-0.73 * * \\
(0.35)\end{array}$ & $\begin{array}{l}1.14^{* * *} \\
(0.36)\end{array}$ & $\begin{array}{c}-0.69 * \\
(0.35)\end{array}$ \\
\hline Overall work satisfaction at $\mathrm{t}=1$ & $\begin{array}{l}-0.06 \\
(0.07)\end{array}$ & $\begin{array}{l}0.03 \\
(0.06)\end{array}$ & $\begin{array}{l}-0.07 \\
(0.07)\end{array}$ & $\begin{array}{l}0.02 \\
(0.06)\end{array}$ & $\begin{array}{l}-0.19 * * \\
(0.08)\end{array}$ & $\begin{array}{l}0.04 \\
(0.07)\end{array}$ & $\begin{array}{l}-0.18^{* *} \\
(0.09)\end{array}$ & $\begin{array}{l}0.03 \\
(0.07)\end{array}$ \\
\hline Unemployed at $\mathrm{t}=1$ & $\begin{array}{l}0.25 \\
(0.23)\end{array}$ & $\begin{array}{l}-0.21 \\
(0.22)\end{array}$ & $\begin{array}{l}0.25 \\
(0.25)\end{array}$ & $\begin{array}{l}-0.20 \\
(0.23)\end{array}$ & $\begin{array}{l}0.50 \\
(0.44)\end{array}$ & $\begin{array}{l}0.36 \\
(0.40)\end{array}$ & $\begin{array}{l}0.63 \\
(0.46)\end{array}$ & $\begin{array}{l}0.51 \\
(0.41)\end{array}$ \\
\hline
\end{tabular}

other variables are omitted. 
Appendix Table A12: Dynamic effects of resident/non-resident care

\begin{tabular}{lccccc}
\hline \hline & \multicolumn{2}{c}{ Female } & & \multicolumn{2}{c}{ Male } \\
\cline { 2 - 3 } \cline { 5 - 5 } Impact of resident care & & & & Non-resident care \\
Years since decision & Resident care & Non-resident care & & Resident care & 0.05 \\
1 & 4.91 & 1.37 & 0.02 & 3.08 & 0.00 \\
2 & 0.16 & 0.00 & & 0.07 & 0.00 \\
3 & 0.01 & & & Non-resident care \\
Impact of non-resident care & & & & 3.21 \\
Years since decision & Resident care & Non-resident care & & Resident care \\
1 & 0.46 & 5.39 & & 1.26 & 0.07 \\
2 & 0.00 & 0.21 & 0.01 & 0.00 \\
3 & 0.00 & 0.01 & 0.00 & 0.00 \\
\hline \hline
\end{tabular}

Notes: Average marginal effects (AMEs), expressed in percentage points, are reported. AME is derived from estimation results from Model 1 - Specification II.

Appendix Table A13: Dynamic effects of main/secondary care

\begin{tabular}{|c|c|c|c|c|}
\hline Impact of main care & \multicolumn{2}{|c|}{ Female } & \multicolumn{2}{|c|}{ Male } \\
\hline Years since decision & Main & Secondary & Main & Secondary \\
\hline 1 & 5.66 & 3.00 & 5.53 & 1.06 \\
\hline 2 & 0.23 & 0.07 & 0.19 & 0.01 \\
\hline 3 & 0.01 & 0.00 & 0.01 & 0.00 \\
\hline \multicolumn{5}{|c|}{ Impact of secondary care } \\
\hline Years since decision & Main & Secondary & Main & Secondary \\
\hline 1 & 4.25 & 7.22 & 1.81 & 5.26 \\
\hline 2 & 0.14 & 0.32 & 0.03 & 0.17 \\
\hline 3 & 0.00 & 0.01 & 0.00 & 0.01 \\
\hline
\end{tabular}

Notes: Average marginal effects (AMEs), expressed in percentage points, are reported. AME is derived from estimation results from Model 1 - Specification II. 